Auglist, 1943

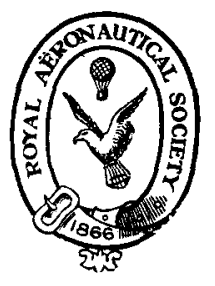

\title{
Abstracts from the Scientific and Technical Press
}

(No. 113. June, 1943)

AND

\section{Titles and References of Articles and}

Papers Selected from Publications

(Reviewed by R.T.P.3).

TOGETHER WITH

List of Selected Translations

(Nos. 56 and 59)

London :

"THE ROYAL AERONAUTICAL SOCIETY"

with which is incorporated "The Institution of Aeronautical Engineers"

4, Hamilton Place, W.I

Telephone: Grosvenor 3515 (3 lines) 
ABSTRACTS FROM THE SCIENTIFIC AND TECHNICAL PRESS.

\author{
Issued by the \\ Directorates of Scientific Research and Technical Development, Air Ministry \\ (Prepared by R.T.P.3.)
}

No. 113. JUNE, 1943.

Notices and abstracts from the Scientific and Technical Press are prepared primarily for the information of Scientific and Technical Staffs. Particular attention is paid to the work carried out in foreign countries, on the assumption that the more accessible British work (for example that published by the Aeronautical Research Committee) is already known to these Staffs.

Requests from scientific and technical staffs for further information of translations should be addressed to R.T.P.3, Ministry of Aircraft Production, and not to the Royal Aeronautical Society.

Only a limited number of the articles quoted from foreign journals are translated and usually only the original can be supplied on loan. If, however, translation is required, application should be made in writing to R.T.P.3, the requests being considered in accordance with existing facilities.

Note.-As far as possible, the country of origin quoted in the items refers to the original source.

The Effect of Compressibility on Thin Slightly Cambered Profiles at Subsonic Speed. (W. Hantzsche and H. Wendt, Z.A.M.M., Vol. 22, No. 2, April, 1942, pp. 72-86.) (1 1 $3 / \mathrm{x}$ Germany.)

The calculation of a steady two-dimensional potential gas flow in the subsonic region can be carried out by a method of successive approximations as shown by Pauzen (1913) and Rayleigh (I916): This corresponds to a development of the potential or stream function in terms of the Mach number, the first approximation being thus that of incompressible flow.

The second and third approximations are applicable to arbitrary profiles and angles of incidence provided the Mach number is small. It would be difficult to calculate the flow for higher Mach numbers by this method, since a large number of steps would be required and the labour involved become excessive.

Prandtl $\left(19^{27}\right)$ and Glanert ( 1928 ) have given an approximation for all subcritical velocities, provided the additional velocities are small compared with the stream velocity (thin profiles at a small incidence). In this case the differential equation for the potential and stream functions assumes the incompressible form of the affine transformation of an independent variable. Following a suggestion by Busemann, the authors have developed a method of successive approximations for the stream function, the first step corresponding to the Prandtl-Glanert approximation. For this purpose, the stream function is develaped in terms of a parameter characterising the deviation of the given profile as regards thickness, curvature coincidence from a line profile at zero incidence. The first term of the series represents the undisturbed parallel flow. With the addition of the 
second term we obtain the Prandtl approximation, whilst the third term allows for finite thickness of profile. The method is applied by the authors to the calculation of the maximum additional velocity for an ellipse (symmetrical flow) and the lift of a Joukousky aerofoil.

The results show that the compressibility effects, taking into account thickness, curvature and incidence of the profile, increase at a slightly greater rate than is given by the Prandtl estimate.

Measurement of the Aerodynamic Forces on Small Wing Models Undergoing. Vibration (Combined Flapping and Twist). (E. V. Holst, J..F.F., Vol. 20 , No. 5, 16/6/43, pp. 1 37-146.) (I I3/2 Germany.)

The article is of interest as giving for the first time accurate measurements on vibrating wings at low Reynolds numbers $(R e \sim 1, \infty 00)$.

The experiments were carried out on a model insect wing, made of balsa wood and ground very thin. The surface is of elliptic plan, slightly cambered, $32 \mathrm{~mm}$. long with a maximum chord of $8 \mathrm{~mm}$. and weighs ig milligram.

The axis about which the vibration takes place is parallel to the longitudinal axis of the wing, but displaced towards the leading edge and passes approximately through the $\frac{1}{3}$ chord position at the maximum width.

The wing is supported on a framework made of $0.2 \mathrm{~mm}$. steel wire, flapping and twisting motion being effected by means of a double crank. The whole system is mounted on a single torsion wire by means of which the thrust (drag) and lift can be determined in succession by a null method.

A most ingenious method for recording the torque is adopted. The driving shaft operating the crank system is split, the coupling consisting of a brass cylinder suspended in an oil bath. The relative velocity between the oil container and the central cylinder is a measure of the viscous torque transmitted and can be obtained by direct calibration.

The average thrust and lift forces of the vibrating wing are of the order of 20 milligram and consistent measurements to within a fraction of a milligram can be obtained on the torsion balance, provided the pertinent factors are kept constant (of these the most important are the frequency of the vibration and the velocity of the incident airstream).

The torque measurements, on the other hand, although reasonably consistent. suffer from the fact that they include the friction in the driving links. The load on the links is partly due to inertia and partly aerodynamic. The friction due to inertia loads can be determined easily by a separate experiment and a suitable allowance made.

The friction due to aerodynamic loads is difficult to determine exactly and no correction has been applied." The author estimates that the recorded torques are throughout about 25 per cent. too high for this reason.

All the experiments were carried out at a constant flapping angle of $68^{\circ}$ (total angular deflection between extreme positions).

The twist amplitude of the wing about the flapping axis could be varied between 0 and ${ }^{1} 5^{\circ}$, the corresponding crank being sloped for this purpose.

Both twist and flap are of the same periad but displaced $90^{\circ}$ in phase, the tests covering frequencies of $10,15,20$ and 25 vibrations/sec. respectively.

Measurements were taken both under static conditions and in the presence of an incident wind.

$$
(v \doteq 50 \text { and } 100 \mathrm{~cm} . / \mathrm{sec} \text {. respectively.) }
$$

In the latter case, the axis of the vibrating wing projected torough a hole in the walls of a miniature ivind tunnel $(6 \mathrm{~cm}$. diameter $)$, the whole of the supporting framework and recording gear being outside the tunnel.

In the case of orthodox aircraft, the thrust and lift producing organs are sharply differentiated (propeller and fixed wings). With a vibrating wing, however, both thrust and lift can be produced by the same mechanism, the inclination 
of the resultant air force being controllable over wide limits, even if the amplitudes of flap and twist remain constant.

As already stated, in the inodel tested by the author, the twist of the blade is $90^{\circ}$ out of phase with the flapping. The mean or zero position of the wing with regard to the flapping plane is however arbitrary and this angle $\tau$ is one of the factors influencing the resultant force.

Two other factors are the angle $\psi$ between the flapping plane and the incident flow and the angle $\alpha$ which the profile makes with the incident flow.

The author investigated the following combinations:-
(i) $\psi=90^{\circ}, x=0^{\circ}, \tau=90^{\circ}$.
(2) $\psi=70^{\circ}, \alpha=20^{\circ}, \tau=90^{\circ}$.
(3) $\psi=45^{\circ}, \alpha=45^{\circ}, \tau=90^{\circ}$.
(4) $\psi=90^{\circ}, x=20^{\circ}, \tau=70^{\circ}$.
(5) $\psi=90^{\circ}, \alpha=45^{\circ}, \tau=45^{\circ}$.
(6) $\psi=70^{\circ}, \alpha=0^{\circ}, \tau=20^{\circ}$.

Each of these settings was tested for various amplitudes of twist (o to $140^{\circ}$ ), vibration frequencies (ro to $25 \mathrm{sec}$ ) and wind speeds (o to $100 \mathrm{~cm} . / \mathrm{sec}$.), the flapping angle being constant throughout $\left(68^{\circ}\right)$.

The results are expressed in terms of non-dimensional parameters, defined as follows :-

where

$$
\begin{aligned}
\text { Thrust coefficient } k_{\mathrm{s}} & =\frac{S}{\frac{1}{2} \rho u^{2} F} \\
\text { Lift coefficient } k_{\mathrm{a}} & =\frac{A}{\frac{1}{2} \rho u^{2} F} \\
\text { Torque coefficient } k_{1} & =\frac{M}{\frac{1}{2} \rho u^{2} F} \\
\text { Thrust efficiency } \eta_{\mathrm{s}} & =\left(k_{\mathrm{s}} / k_{1}\right) \lambda \\
\text { Static thrust performance } \xi & =k_{\mathrm{s}} /\left(2 k_{1}\right)^{2 / 3}
\end{aligned}
$$

$$
\begin{aligned}
S & =\text { thrust. } \\
A & =\text { lift. } \\
M & =\text { torque. } \\
u & =\text { mean tip speed of wing due to flapping. } \\
v & =\text { incident air speed. } \\
\lambda & =\text { speed ratio } v / u . \\
F & =\text { area swept during one complete flapping. }
\end{aligned}
$$

\section{Discussion of Results.}

(1) $\psi=90^{\circ}, \alpha=0^{\circ}, \tau=90^{\circ}$.

This symmetrical vibration produces thrust only, the motion resembling that of a propeller.

Plotted on a $X$ basis (amplitude of twist) with frequency $n$ as parameter, the $k_{\mathrm{s}}$ curves are roughly parabolic, a maximum value of .08 being reached at $X=90^{\circ}$.

Under static conditions (absence of incident wind) the frequency has very little effect. In the presence of an incident wind, the $k_{\mathrm{s}}$ curves separate in the order of their frequency, the separation being the more marked, the higher $v$.

Plotted on a $\lambda$ basis, $k_{s}$ diminishes almost linearly with $\lambda$, the steepness of the curves increasing as the parameter $X$ increases.

Optimum thrust efficiency: $\left(\eta_{\mathrm{s}}=.45\right.$, not allowing for friction) occurs at $\lambda=.5$ and $X=90^{\circ}$.

Under static conditions, $\eta_{\mathrm{s}} \max$. is about .4 at $X=120^{\circ}$.

[In the case of insect flight, considerably higher thrust efficiencies are no doubt possible, the wing in this case being flexible and set at the optimum incidence during each phase of the motion.] 
(2) $\psi=70^{\circ}, \alpha=20^{\circ}, \tau=90^{\circ}$.

The plane of flapping now makes an angle of $20^{\circ}$ with the incident air stream. Both thrust and lift are produced, the relative proportions of each depending on $X$ and $\lambda$. It is thus possible to direct the resultant air force in almost any required direction.

For any given value of $\lambda$, the resultant force becomes a maximum for a given value of $X$ which decreases as $\lambda$ increases:---

$\begin{array}{lcccc}\lambda & 0 & .4 & .8 & \text { i.o } \\ X & 100^{\circ} & 70^{\circ} & 50^{\circ} & 40^{\circ} \\ k_{\mathrm{a}} & .025 & .06 & .11 & .15 \\ k_{\mathrm{B}} & .07 & .05 & .01 & -.01\end{array}$

Whilst, just as in Case $I, k_{\mathrm{B}}$ diminishes with increasing $\lambda$, the slope being roughly proportional to $X$, the reverse holds for $k_{\mathrm{a}}$.

Thus, a large amplitude of twist is beneficial for producing thrust but the lift coefficient becomes highest at small amplitudes.

The power absorbed by the vibration is practically identical with that of the previous case, i.e., the high lift forces do not require extra work. The thrust efficiency curves are not markedly affected, apart from being compressed into a smaller $\lambda$ range. The optimum thrust efficiency is unaltered.

(3) $\psi=45^{\circ}, x=45^{\circ}, \tau=90^{\circ}$.

The lift coefficient increases still further whilst the thrust is reduced. The maximum resultant force (split up into thrust and lift components) is given in the following table:--

$\begin{array}{lllr}\lambda & 0 & .4 & .6 \\ X & 100^{\circ} & 90^{\circ} & 70^{\circ} \\ k_{\mathrm{a}} & .065 & .115 & .150 \\ k_{\mathrm{s}} & .065 & .02 & -.025\end{array}$

The thrust efficiencies are considerably reduced (optimum value $=.28$, uncorrected for friction) and the range over which a positive thrust can be produced is shortened still further $(\lambda=0$ to $\cdot 5)$.

(4) $\psi=90^{\circ}, x=20^{\circ}, \tau=70^{\circ}$.

In this case the incident air stream is perpendicular to the flapping plane, lift and thrust being produced by a change in the zero position of the wing, the mean position now making an angle of $70^{\circ}$ with the flapping plane.

The incidence $\alpha$ is thus the same as in Case (2) considered above. The thrust coefficients are, however, appreciably less, whilst the lift coefficients somewhat higher.

The optimum thrust efficiency is reduced to .2 at $\lambda=.3^{\circ}$.

The maximum resultant force components are given below :-

$\begin{array}{lllll}\lambda & 0 & .4 & .6 & .8 \\ X & 100^{\circ} & 70^{\circ} & 70^{\circ} & 60^{\circ} \\ k_{\mathrm{a}} & .055 & .08 & .10 & .12 \\ k_{\mathrm{s}} & .07 & .035 & .01 & .015\end{array}$

(5) $\psi=90^{\circ}, \alpha=45^{\circ}, \tau=45^{\circ}$.

Practically no thrust is produced, whilst the lift is no greater than in Case (4).

The reason for this marked difference in behaviour is investigated by the author. It appears that in Cases (r)-(3), the resultant forces are mainly due to the circulation round the profile, whilst in (4) and (5) the drag of the aerofoil plays an important part (broadside motion during part of stroke). This explains the much greater efficiency of the forner type of vibration. 
(6) $\psi=70^{\circ}, \alpha=0^{\circ}, \tau=20^{\circ}$.

This type of vibration is of special interest since an appreciable lift is produced, although the mean blade incidence is zero. At the same time the thrust coefficient differs only little from Case ( $\mathbf{r}$ ).

The inclination of the flapping plane, whilst retaining zero mean incidence causes a difference in the effective angle of incidence in the up and down strokes, resulting in a lift component which is negative unless $X<30^{\circ}$.

There are thus three possible ways of producing a lifting force with a vibrating wing system :-

(a) Tilting of flapping plane, wing twist symmetrical with regard to plane ((2) and (3) above).

(b) Flapping plane normal to incident wind, wing twist unsymmetrical ((4) and (5) above).

(c) Flapping plane inclined, any twist symmetrical with regard to incident wind $((6)$ above).

A large scale mechanical imitation of the flapping flight. of birds or insects is not feasible. On account of the close connection with helicopter problems, however, the vibrating wing is of great theoretical interest. This aspect of the problem will be dealt with by the author in a subsequent paper.

Device for the Automatic Limitation of the Aircraft Acceleration in a Vertical Direction. (Potez Patent No. 733,589, Patent Series No. 4, p. 26; Flugsport, Vol. 35, No. 9, 19/5/43.) (I $3 / 3$ France.)

Principal Claims.

Device for the automatic limitation of the vertical acceleration of aircraft consisting of a split control rod system consisting of two parts capable of undergoing mutual displacement along the same axis and held together by a tension spring, characterised by the fact that the ends of the control rods facing each other are fitted with pivoted cross bars, which serve as attachment for the tension spring and floating link respectively, which are thus placed on opposite sides of the control rod centre line.

At the floating link end, the cross bars are provided with right angled extension pieces to which inertia masses are attached.

A vertical acceleration of the aircraft thus causes an extension or contraction of the spring coupling and the corresponding change in the length of the control rod systems causes a corresponding change in the elevator deflection. The inertia device only becomes effective if the aircraft is undergoing vertical acceleration and reduces the possible elevator deflection corresponding to a given control stick deflection. If the aircraft is flying steadily, full deflection is restored.

Device for the Dynamic Stabilisation of Aircraft. (Junkers Patent No. 733,588, Patent Series No. 4, pp. 25-26; Flugsport, Vol. 35, No. 9, 19/5/43.) (I $3 / 4$ Germany.)

The basic feature of the patent consists in the introduction of a phase lag between the operation of the elevator and the displacement of the aircraft with the object of damping out longitudinal oscillations rapidly. If $T=$ periodic time of such oscillations, the optimum phase lag is about $T / 4, e . g$. , maximum elevator deflection in a downward direction occurs $T / 4$ seconds after the maximum vertical acceleration of the aircraft or at the instant of zero acceleration.

This is achieved by coupling the elevator control rod to an elastically suspended mass capable of executing vibrations in a vertical direction, these vibrations being transmitted by means of a ratchet to a flywheel the axis of rotation of which is at right angles to the longitudinal axis of the aircraft. 
Instead of having separate oscillating and rotating masses, the desired effect can also be produced by utilising parts of the existing control rod and elevator systems.

(Since only a digest of the patent is given, the constructional details are not clear. It is of interest to note that a somewhat similar device appears to be fitted to the Soviet Lagg 3 Fighter (see R.T.P. Translation No. 1822).)

Vision, Hearing and Aeronautical Design. (L. D. Carson, W. R. Miles and S. S. Stevens, J. Aeron. Sc., Vol. 10, No. 4, April, 1943, pp. I 27-1 $3^{\circ}$.) (1 $13 / 5$ U.S.A.)

Vision.

It is desirable that pilots, observers and engineers "should be placed as near as possible to the aircraft windows. This not only increases the angle of vision, but it is also generally easier to provide the requisite transparent area free from opaque accessories. At the same time, blemishes or scratches in the window, being out of focus, are less bothersome. For this reason turrets in which the guns are mounted at the side and rather low down are preferable to the orthodox type in which the gunner is placed behind the gun. In the latter case, it is difficult to reduce the distance between eye and window (aiming panel) below 29 inches ( 9 inches from eye to gunsight and 20 inches between sight and aiming panel). The field of vision in this case is only about $28^{\circ}$ (tunnel vision) and may possibly be obstructed moreover by the gun structure and window frames. With lateral guns a much closer position to the front panel should generally be possible for the gunner.

Special attention should be paid to the instrument lighting, especially at night. Excessive illumination has serious effects on the eye adaptation for night vision. For this reason the illuminated area should be restricted to the utmost and only red light used $(600 \mu \mu)$. It is well known that the tendency to air sickness is reduced, if visual contact with the ground can be maintained.

Many troop carrying gliders suffer from this defect with the result that the fighting efficiency of the men after landing may be seriously affected.

\section{HEARING.}

Both propelier slipstream and engine noise depend on the horse-power, and with the larger power plants now coming into general use, the noise problem becomes serious.

Even if the engine and propeller could be silenced, the hoise associated with the turbulent air stream passing over the fuselage is very considerable. Thus it is almost impossible to hold a conversation inside a glider towed at $150 \mathrm{~m}$.p.h., the noise level being of the order of I $_{5} 5$ decibel.

The most important practical effect of aircraft noise is the masking of communications. Articulation tests have shown that with standard military interphone equipment a listener is only able to understand about 50 per cent. of the spoken words in the presence of a background noise of $120 \mathrm{db}$. Matters can be improved by the provision of absorbent material which, although not reducing the overall noise level appreciably, does cut down the harmful high frequency components and facilitate conversation. Another remedy consists in improving the response characteristic of the microphone and earphone (high fidelity) and in shielding these instruments as far as possible from extraneous sounds.

The oxygen mask provides facilities for microphone shielding which is still often neglected. The earphone and the ear of the listener can be shielded by means of an acoustic socket forming a tight seal against the side of the head.

Both seeing and hearing, if accompanied by prolonged attentive effort, causes fatigue and loss of efficiency of the crew. Elaborate precautions are taken to ensure the proper function of the aircratt mechanism under modern arduous 
condition of operation. The authors make a plea that at least equal attention be paid to the physiological requirements of the flying personnel.

True Air Speed Indicator. (R. D. Gibson, U.S.A. Patent No. 2, 318; 153.) ( $1 \mathrm{r} 3 / 6$ U.S.A.)

'The normal air speed indicator measures the velocity head $\frac{1}{2} \rho V^{2}$ and its indications therefore depend on the density $\rho$ as well as on the relative air speed $V$.

If such an instrument has been calibrated under standard ground level conditions $\left(p=760 \mathrm{~mm}\right.$., $\left.T=288^{\circ} C_{\mathrm{A}}\right)$, the true air speed at pressure $p$ and temperature $T$ is obtained by multiplying the indicated air speed by the factor

$$
\sqrt{ } 760 / p \times \sqrt{ } T / 288
$$

The invention of the author consists in applying this correction automatically by means of an electrical circuit, the true air speed being recorded on a special type of watt meter.

For this purpose the normal air speed indicator controls a rheostat $\left(R_{\mathbf{I}}\right)$ in series with the fixed coil (3) of the watt meter and a battery. Coil (3) is of low resistance compared with the rheostat, so that the current passing through this circuit is determined mainly by the position of the variable contact on the rheostat.

It is convenient to design the rheostat and linkage mechanism such that the current $C_{3}$ through coil (3) is directly proportional to the indicated air speed. The necessary linkage mechanism is not described, but reference is made to known designs which could be utilised for the purpose (U.S.A. Patents $2,178,422$ and $2,137,194$ are quoted as examples).

The moving coil (4) of the watt meter is shunted with a second rheostat $\left(R_{2}\right)$ controlled by the barometric pressure (altimeter) and connected in series with a thifd rheostat $\left(R_{3}\right)$ similarly controlled by an air temperature meter. The whole circuit is fed by the same battery already supplying the fixed coil (4). The resistance of $\left(R_{2}\right)$ is relatively low compared with $\left(R_{3}\right)$ and $(4)$ and varies inversely as the square root of the pressure. (U.S.A. Patent No. 2,251,498 is quoted as an example for producing the necessary linkage.)

Rheostat $\left(R_{3}\right)$ has a relatively high resistance and therefore controls the total current $C_{1}$ flowing through the circuit containing $\left(R_{2}\right)$ and $(4)$ in parallel.

$\left(R_{3}\right)$ is controlled by a temperature indicator in such a way that the total current $C_{1}$ varies directly as the square root of the absolute temperature.

We thus have

$$
\begin{aligned}
& R_{2}=K_{2} \sqrt{ } 760 / \rho \\
& C_{1}=K_{3} \vee T / 288
\end{aligned}
$$

Since $\left(R_{2}\right)$ is small compared with $(4)$, nearly all the current $C_{1}$ passes through $R_{2}$, producing a voltage drop $C_{1} R_{2}$, which corresponds to the voltage applied to the moving coil.

The current $C_{2}$ passing through the moving coil is therefore given by

$$
C_{2}=K_{4} C_{1} R_{2}=K_{5} \sqrt{ } 760 / \rho \cdot \sqrt{ } T / 288
$$

The indication of the watt meter is the product $C_{2} C_{3}$ and corresponds therefore to

$$
K \sqrt{ } 760 / \rho \times \sqrt{ } T / 288 \times \text { indicated air speed. }
$$

'The density correction required by equation (I) above has thus been incorporated automatically in the watt meter reading, the scale of which gives true air speed.

A Method for Rapid Estimation of Helicopter Performance. (Q. Wald, J. Aeronautical Sciences, Vol. Io, No. 4, April, 1943, pp. 13 ${ }^{\mathrm{I}-\mathrm{I} 35 .)}$ (I I3/7 U.S.A.)

Several papers are available which treat the analysis of rotating wing aircraft with considerable rigour and completeness. While these treatments are satis- 
factory for exhaustive analyses of specific helicopters, they are exceedingly complex. Since simple methods of performance estimation are available for aeroplanes, it is believed that a comparable system for helicopters should prove useful for comparative performance studies, preliminary estimation of characteristics of proposed designs, and determination of the effects of small changes in design. Frequently, only limited data are available for studies of this type, making elaborate analyses impossible or undesirable. The present report proposes a system of performance estimation which, it is hoped, will fulfil the need. The method is relatively simple and rapid.

The method is based on the conception of the rotor as an actuator disc and the well-known momentum relations for an actuator disc. All of the major variables in design and operation are taken into account. Comparisons have indicated that the results obtained by this system are good approximations to the results of more elaborate analysis.

A Tabular Method of Propeller Blade Stress Analysis. (Joseph Stuart, Journal of the Aeronautical Sciences, Vol. Io, No. 4, April, I943, pp. II5-II8.) (1 $13 / 8$ U.S.A.)

A tabular, trial-and-error method of evaluating the steady bending stresses in a rotating propeller blade is developed and examples of the application are given. The bending moment at a shank section of the blade is estimated and, by tabular integration, the corresponding radial bending moment distribution is calculated. Additional trials with appropriately revised shank section bending moment estimates are made until the correct distribution is found, having the physically required moment value of zero at the blade tip.

Tilted blades and blades whose section centres of gravity do not in general fall on the blade axis are shown to be readily analysed. Because the final analysis can be quickly checked on a calculating machine and because the method is easily learned, versatile and fast, its general adoption by the propeller industry is advocated.

General Equations for the Analysis of Elliptical Rings. (D. O. Dommasch, J. Aeronautical Sciences, Vol. Io, No. 4, April, 1943, pp. I 19-126.) (1 13/9 U.S.A.)

The analysis of bulkhead rings is at best a tedious process, and it is felt that any simplifications will be of help to the aircraft structural engineer.

Of the several methods of analysis available, that outlined in N.A.C.A. Technical Report No. 509 (1934) seems to be. the simplest and most widely used. This paper is based on the general method of the N.A.C.A. report and presents, in particular, the application of the report to elliptical and circular frames. In addition, some general simplifications based on symmetry and load conditions are presented.

No attempt has been made to break down the analysis into a number of specific solutions, but rather simplifications of the basic equations are presented which apply to any loading condition.

A set of curves is presented at the end of this article from which the length, moment of length, and moment of inertia of the length of an ellipse may be determined.

General Instability of Monocoque Cylinders. (N. S. Hoff, J. Aeron. Science, Vol. 10, No. 4, April, 1943, pp. 105-114, i 3 o.) (r $3 /$ Io U.S.A.)

General instability is defined as the simultaneous buckling of the longitudinal and transverse reinforcing elements of a monocoque structure. There are several types of instability'satisfying this definition which differ markedly in the distortion pattern and value of the critical load. 
Types already described in literature include:-

I. Flattening in Compression.-In this case the original circular rings distort to ellipses and the originally straight stringers to sine curves of one or more half wave lengths.

2. Diamond Pattern in Compression.-The deflections are sinusoidal in both the longitudinal and circumferential directions and usually consist of several half waves in either direction.

(Type $I$ is a special case of the diamond pattern when there are four half waves in the circumferential direction.)

3. Flattening in Bending.-The structure undergoes considerable elastic deformation under a pure bending moment and collapses suddenly when the flattening exceeds a certain value.

4. Inward Bulge in Bending.-The bulge develops symmetrically to the most highly stressed fibres in compression, the tension side of the structure remaining smooth.

Of the above types No. $\mathrm{r}$ and 3 are of like practical interest to the aircraft designer since they entail a stringer-ring-skin combination not likely to occur in practice.

The buckling load of the diamond pattern (type 2) of general instability has been calculated by a number of authors, the actual monocoque being replaced by an equivalent orthotropic shell possessing suitable bending rigidity distributed in the longitudinal and circumferential directions. Agreement with practice is reasonably good, provided experimental values for the stiffness are included.

Many attempts have been made to apply such buckling formulæ to the calculation of the critical stress under bending, t being assumed that this stress must be substantially the same as that in compression if the wave formation occurs only in close proximity of the most highly stressed compression fibre.

Agreement with practice is, however, very poor, the experimental critical stress being always considerably lower and reaching in some cases only $\mathrm{r} /$ ro of the predicted value.

The author suggests that this is mainly due to the diamond type of distortion (on which the theory is based) not being retained when bending takes place. For this reason, a type of distortion known to occur in certain cases of bending (inward bulge, type 4) is investigated theoretically, the buckling load being calculated by the Rayleigh-Ritz-Timoshenko method, the strain energy stored in the sheet being first neglected. . Although in some cases the experimental buckling load was in fair agreement with the theoretical prediction, in others the calculated values were less than $1 / 9$ of the practical critical load.

In the present paper, the author revises his original theory to allow for the effect of the covering sheet. A simple formula is derived, which, although it is based on a series of assumptions gives reasonable agreement with practice provided experimental values for the wave form of the buckle (inward bulge) are. available.

Instructions for carrying out the necessary calculations are given in detail.

Mobile Unit for the Periodic Cleansing of the Lubricating System of Machine Tools. (Flugsport, Vol. 35, No. 9, I9/5/43, pp. III-II2.) (II3/II Germany.)

Modern machine tools are provided with two lubricating systems, one of which supplies lubricating oil to the gears and bearings whilst the other handles the cooling oil supplied to the tool.

In the past such machines were lubricated by the operator in a rather haphazard manner and insufficient attention was paid to the removal of oil sludge. This sludge contains minute particles of metal which in course of time cause serious troubles in the bearings and gears. 
It is now recognised that the proper maintenance of such tools should be in the hands of a special staff and in order to facilitate this, the Junkers firm have designed a special mobile unit containing all the necessary tools as well as supplies of fresh oils. Of special interest is an electrically heated tank of cleansing fluid which can be pumped through the oil tanks and supply pipes of the machine tool to ensure the complete removal of sludge and dirt prior to refilling with new oil.

Needless to say, the old oil is also drawn off by a pump carried on the unit and the supplies collected in this manner are subsequently regenerated. By having all the pump circuits integral with the unit, the cleansing operation can be carried out very quickly and the truck dimensions are such that mobility in' the shop is ensured.

\section{Plexiglass-Properties and Fabrication. (Reference Sheet No. 7-8, Flugsport,} Vol. 35, No. 9, 19/5/43, pp. 1 I 2a-b.) (II3/12 Germany.) .

Plexiglass is a thermoplastic of the acryl resin class and is available in plate form in a series of standard sizes ranging in thickness from $1 \mathrm{~mm}$. to $8 \mathrm{~mm}$. and in superficial area from $600 \times 400 \mathrm{~mm}$. to $1,600 \times \mathrm{I}, 100 \mathrm{~mm}$.

The following table gives some of the physical constants:-

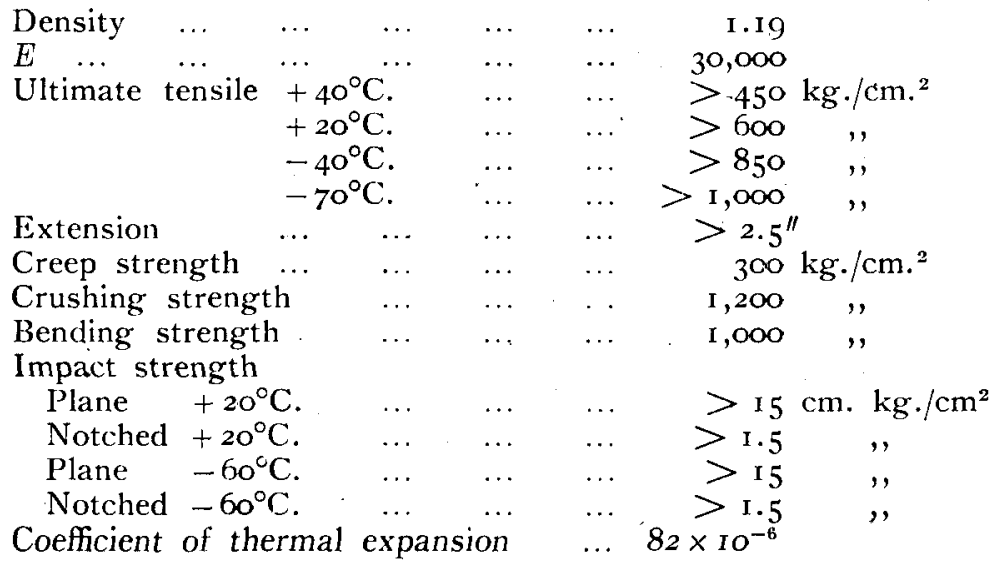

Both creep and notch sensitivity must be considered when designing stressed parts. Attention must also be given to the possibility of stress-corrosion in the presence of organic solvents such as petrol and turpentine.

Single directions for cutting, milling, turning, boring and polishing the material are given. All the ordinary machine tools are suitable for these processes, especially those employed in wood working. Care must be taken to prevent overheating the materials and the worked surface must be cooled with water, compressed air or a non-lubricating cutting fluid.

Since no amount of subsequent polishing can replace the surface produced by the makers, it is essential that a suitable cover of paper or paste be provided for those parts not in contact with the tool.

Plexiglass can be easily moulded, either by laying the sheet (previously softened by warming to $120-150^{\circ} \mathrm{C}$.) over a former and pulling down the edges or by blowing. 'The latter process gives the better optical surface.

The very high coefficient of thermal expansion of plexiglass (over three times that of aluminium) calls for special care in the installation. It is essential that stresses be avoided as they may lead to corrosion cracks which are detrimental to clear vision. On account of the high notch sensitivity, care must be taken to avoid all sharp corners. The usual procedure is to recess the glass slightly along the edge and grip it between two metal plates (above and below) fitted 
with rubber pads which are tightened by means of a. screw passing through a well rounded slot in the glass. Sufficient space must be left between the edge of the recess and the metal plates to allow for expansion.

The.Ju. 87 Equipped for Medical Flight Research. (H. V. Diningshofen, Flugsport, Vol. 35, No. 9, I9/5/43, pp. 108-1 I r.) (I I3/13 Germany.)

The experiments were concerned mainly with the effects of acceleration on the human organism and covered more than 200 flights, the author, who is a well known doctor, acting as pilot throughout.

By flying tight spirals during a dive it is easy to obtain centrifugal acceleration of the order of $8 \mathrm{~g}$. for periods up to 5 seconds. Under these conditions the airspeed of the Ju. 87 does not exceed 200 m.p.h. and the control forces are relatively low. There is also a complete absence of vibration and the author is enthusiastic about the ease of handiing of the particular aircraft, making it admirably suited for the investigation in hand.

For the experiments, the Ju. 87 carried two passengers, test subject and observer. The former is normally seated in an upright position, facing the direction. of flight. The observer faces him, with his back to the direction of flight. A Siemens hot cathode X-ray apparatus (fed from an accumulator battery. through a special transformer) is placed immediately behind the test subject, who carries a fluorescent screen strapped to his chest. In this manner the observer can examine the variation in blood content of the heart and lungs of the test subject during various manœuvres. The $\mathrm{X}$-ray set is sufficiently powerful to enable photographic reproduction at the relatively short exposure time of I. 5 seconds. film.

The facial' expression of the test subject is recorded independently on a cine

About 200 test flights covering 22 different subjects were carried out, the highest acceleration being $8.5 \mathrm{~g}$. for 3 seconds.

It is interesting to note that by adopting a crouching attitude, both pilot and observer withstood this acceleration without disturbance of vision.

In the upright position and completely relaxed, all the test subjects could withstand $4 \mathrm{~g}$. for a period of 5 seconds without any ill effects.

The following table gives the acceleration limits. on a percentage basis:-

$\begin{array}{cccc}\% \text { of Subjects. } & \text { Misty Sight. } & \text { Blackout. } & \text { Collapse. } \\ 8 \mathrm{o} & 5 \mathrm{~g} . & 5.5 \mathrm{~g} . & 6 \mathrm{~g} . \\ 50 & 6 \mathrm{~g} . & 6.75 \mathrm{~g} . & 7.5 \mathrm{~g} . \\ 20 & 6.5 \mathrm{~g} . & 7.5 \mathrm{~g} . & 8.0 \mathrm{~g} .\end{array}$

Provided the acceleration has not lasted longer than 5 seconds, the subject recovers consciousness within 2-3 seconds after acceleration has been reduced below $3 \mathrm{~g}$.

The disturbance level can be raised about $2 \mathrm{~g}$. if the subjects adopts a crouching attitude with full muscular contraction. About two-thirds of the subjects tested were capable to withstand acceleration of the order of $8-9 \mathrm{~g}$. by this means, without any disturbance of vision for periods up to 5 seconds.

Much higher limits are made possible if a prone position is adopted. Centrifugal tests have shown that under these conditions up to $15 \mathrm{~g}$. can be withstood for 2 minutes, although breathing became very difficult.

The X-ray photographs show that the so-called acceleration collapse in its most severe and dangerous form is due to a complete failure of the blood circulation. Under the action of the rentrifugal force, the blood is drained away from the heart and accumulates in the lower blood vessels, especially the legs. When this accumulation exceeds a certain amount the heart delivery ceases and the lungs are no longer fed with blood. For the relatively short exposure times and limited $g$. values occurring in aerial combat, however, this complete failure 
of the heart pumping only occurs rarely. In the majority of cases, the main blood circulation is maintained. The rate of blood supply to the eyes and brain is however insufficient to maintain proper functioning. Under these conditions, collapse occurs although the X-rays show that both heart and lungs are still filled with blood. By adopting a crouching attitude, the work required to raise the blood to the brain is reduced and a minimum supply can be maintained for a short period.

Considering that already at $7 \mathrm{~g}$., the blood has a density corresponding to that of liquid iron, the difficulties of maintaining even a minimum blood circulation for any length of time can be realised.

It is interesting to note that with lack of oxygen (imminent altitude sickness) the resistance to acceleration drops rapidly and collapse may occur in 2-3 seconds at $3 \mathrm{~g}$.

\section{LIST OF SELECTED TRANSIATTIONS.}

\section{No. $5^{6 .}$}

Note.-Applications for the loan of copies of translations mentioned below should be addressed to the Secretary (R.T.P.3), Ministry of Aircraft Production, and not to the Royal Aeronautical Society. Copies will be loaned as far as availability of stocks permits. Suggestions concerning new translations will be considered in relation to general interest and facilities available.

Lists of selected translations have appeared in this publication since September, 1938.

\section{AERo AND Hydrodynamics.}

TRANSLATION NUMBER

AND AUTHOR.

1734 Wieselsberger, O....

${ }_{1738}$ Betz, $\Lambda$.

I0o Knornschild, S.

1747 Smirra, J. . .

$175^{8}$

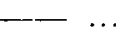

1735

Emicko, G... Lucas, H. ... Eisen, J.
1736 Bauer, R. ... ... The Determination of Zinc in Aluminium and

\section{TITLE AND REFERENCE.}

The. Influence of Wind Tunnel Boundaries on Resistance Especially in a Compressible Flow. (L.F.F., Vol. I9, No. 4, 6/5/42, pp. I 24-1 28.)

The Velocity Profile in the Neighbourhood of a Wall of Discontinuous Curvature. (L.F.F., Vol. 19, No. $4,6 / 5 / 42$, pp. I29-I3I.)

\section{Engines And Accessories.}

The Polytropic Efficiency of a Compressor. (L.F.F., Vol. I9, No. 6, 20/6/42, pp. I83-188.) (Translated by Rolls' Royce, Ltd.)

Cylinder Arrangements for Aircraft Power Plants. (Luftwissen, Vol. 9, No. 7, July, I942, pp. 210-225, and No. 8, Aug., 1942, pp. 234-237.)

A New Swedish Two-Stroke Engine. (A.T.Z., Vol. 45 , No. $9,10 / 5 / 42$, pp. $25^{1-2} 53$.)

\section{Materiar s.}

Fundamental Investigations on the Cold and Hot Rolling of Metal into Sheet and Strip with Special Reference to Aluminium and Wrought Aluminium. (Z.f. Metal, Vol. 34, No. 2-3, 1942, pp. $25-3^{8}$ and $49-55$.) Aluminium Alloys. (Metal and Erz, Vol. 39, No. 6, 1942, pp. 100-106.) 
TRANSLATION NUMBER

AND AUTHOR.

TITLE AND REFERENCE.

Pressure Cabin (Digest of Gbrman Patents).

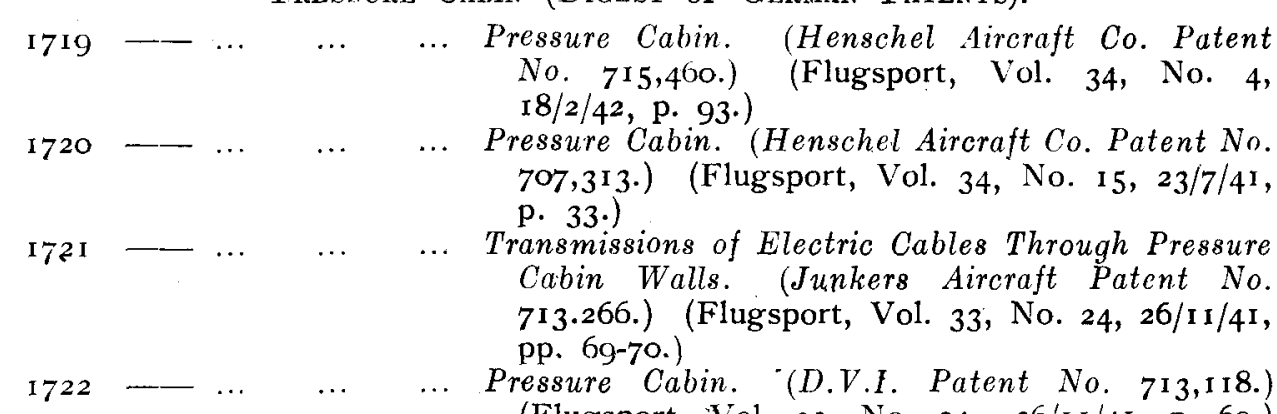
(Flugsport, Vol. 33, No. 24, 26/1 I/41, p. 69.) $1723 \quad \ldots \quad \ldots \quad \ldots$ Aircraft Fuselage with Pressure Cabin. (Messerschmidt Airc. Patent No. 714,018.) (Flugsport, Vol. 34, No. I, 7/1/42, p. 81.)

$1724 \quad \ldots \quad \ldots \quad \ldots$, Operation of Aircraft Guns on High Altitude Aircraft. (Patent No. 751,572.) (Rev. Ae. l'Armee de 1'Air, No. 5, April, 1938, pp. 475-477.)

1725 - ... ... ... Aircraft Gun Mounted Externally to a Pressure Cabin. (German Patent No. 598,25I.) (Flugsport, Vol. 26, No. 13, $27 / 6 / 34$, pp. $85-86$.)

$1726 \quad \ldots \quad \ldots \quad \ldots \quad$ Double-Walled Pressure Cabin. (German Patent No. 595;504.) (Flugsport, Vol. 26, No. I I, 30/5/34, p. 81.)

$1729 \quad \ldots \quad \ldots \quad \ldots \quad$ Double-Walled Pressure Cabin. (German Patent No. 714,784.) (Flugsport, Vol. 34, No. 2, $2 \mathrm{I} / \mathrm{I} / 4^{2}$, p. 85.$)$

Miscelianeous.

${ }_{1705}$ Stettler, O.... .. Electrical Extension-Measurements on Materials. (Flugwehr und Technik, Vol. 4, No. 8, i942, pp. 2I 2-2I4.) (Translated by Rolls Royce, Ltd.)

1708 Gebelein, H. ... The Statistical Problems of Correlation as a Variation and Characteristic Value Problem and its Connection with Mean Valve Calculations. (Z.A.M.M., Vol. 21, No. 6, Dec., 1941, pp. 364-379.)

${ }_{1727} \quad \ldots \quad \ldots \quad \ldots$ Turbulent Wing “Diruttore." (Flugsport, Vol. 28, No. I $3,27 / 6 / 34$.)

$177^{2}$ Donatsche, H. ... Possible Evasive Mancuvres of Aircraft Under A.A. Fire. (Flugswehr und Technik, Vol. 4, No. 6, June, 1942, pp. I 4 I-I 44 .)

No. 59 .

Aero and Hydrodynamics.

TRANSLATION NUMBER AND AUTHOR.

I816 Hubert, J
TITLE AND REFERENCE.

... Model Experiments on Aerofoils with Various Degrees of Sweep Back, with and without End Plates. (Jahrbuch d. deutsche I.uftfahrtforschung, Vol. I, I937, pp. I 29-139.) 
ABSTRACTS FROM THE SCIENTIFIC AND TECHNICAL PRESS.

TRANSLATION NUMBER

AND AUTHOR.

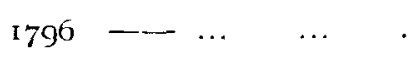

I 8 r 4 Prandtl, L. ...

... Fluid Motion in Rotating Impellers. (V.D.I., Forschungsheft, No. 405, 1940, pp. I-2I.)

... Sound Propagation Associated with High Velocity Source. (Schriften Akademic Luftfahrtforschung, No. 7.)

\section{Aircraft and Accessortes.}

I 797 Schmidt, R.

I809 Pistolesi, E.

.. Comparison of Various Methods for Determining Flight Speed at Great Altitudes. (Luftwissen, Vol. 9, No. 9, Sept.. 1942, pp. 270-275.)

... Mutual Interference Between Airscrew and Fuselage, with some other Airscrew Problems. (L. Aeretunica, Vol. 22, No. 6, June, 1942, pp. 255-287.)

\section{Engines and Fuels.}

1790 Uggla, W. R. ... The Hertzian and Hydraulic Pressure on Gear Teeth. ('Teknish Tidskrift, Vol. 69, No. 3, 2 I/I/1939, pp. 8-II.)

1795 Haug, K.

Comparative Investigations on the Torsional Stiffness of Automobile Engine Crankshaft. (A.T.Z., Vol. 43 , No. $16,25 / 8 / 40$, pp. 393-402.) =

\section{Materials.}

${ }_{1805}$ Rege, A. . .

1807

I8I I Panseri, C. ... Monticelli, M.

I 808 Nagel, $M$

I798 Schmidt, R...

1800 Magnus, $\mathrm{K}$.

Klughardt, $\mathrm{A}$

I810 Spaeth, W...
On the Sheathing of Iron and Steel Flectrodes Used for Arc Welding. (Metallurgia Italiana, Vol. 30, No. 12, Dec., 1938, pp. 697-719, No. I-2, Jan.Feb., 1939, pp. I-16 and 69-84.)

The Behaviour of Certain Structural Materials in the Tropics. (A.T.Z., Vol. 44, No. 12, 25/6/41, pp. 316-3.17.)

On the Correct Interpretation of Certain Phenomena Observed During Thermal Treatment of 'Aluminium Alloys. (Alumino, Light Metal Research Institute, Milan, pp. I83-191.)

\section{In STRUMENTS.}

.. Dornier Air Log. (Jahrbuch der deutschen Luftfahrtforschung, 1938, Vol. I, pp. $5^{8} 3^{-5} 5^{8}$.)

... Some Notes on and Experiments with the Artificial Horizon, with Special Reference to the Sperry Type. (L.F.F., Vol. 19, No. 2, 20/3/42, pp. 23-24.)

... Experiments on the Performance and Performance ... Impression of Telescopes. (Z. f. Instrum., Vol. 62, No. I, Jan., 1942, pp. i6-18.)

... A Vibrating Table for Testing Instruments. (Z.V.D.I., Vol. 81, No. 1, Jan., 1937, p. 12.) 
TRANSLATION NUMBER

AND AUTHOR.
TITIE AND RHFERENCE.

Elastic Theóry.

I8I7 Schiebold ... ... A Contribution to the Theory of the Measurement of Elastic Stresses in Materials by the X-Ray Interférence. Method. (Berg und Hütte, Monatsheft, Vol. 86, No. 12, Dec., 1938, pp. 273-295.) ${ }_{1} 80_{3}-\ldots \quad \ldots \quad \ldots \quad$ The Study of Residual Stresses Due to Bending. (J. Tech. Phys., U.S.S.R., Vol. 9, No. I2, 1939, pp. I, I I 2-I I I 24.)

WiRELESS.

${ }_{1815}$ Ruckert, H. ... Apparatus for Measurements in the Ultra-Short Wave Band. (F.T.M., No. 8, 1942, pp. 105-III.) 179.2 Burkhard, O. ... Seasonal Vibrations in Height and Ionization of the $V_{2}$ Layer. (H.F.T., Vol. 6o, No. 4, Oct., 1942, pp. 97-99.)

1793 Grosskopf, J. ... Measurements on the Propagation of Wave Over a Vogt, K. ... ... Non-Homogenous Surface. (H.F.T., Vol. 6o, No. 4, Oct., I942, pp. 97-99.)

$1804 \quad \ldots \quad \ldots \quad \ldots \quad$... Absolute Voltage Measurements in the Decimetre Wave Range. (H.F.T., Vol. 58, No. I, July, 1942, pp. 32-35.) 
TITLES AND REFERENCES OF ARTICLES AND PAPERS SELECTED FROM PUBLICATIONS REVIEWED IN R.T.P.3.

Requests for further information or translations should be addressed to R.T.P.3, Ministry of Aircraft Production.

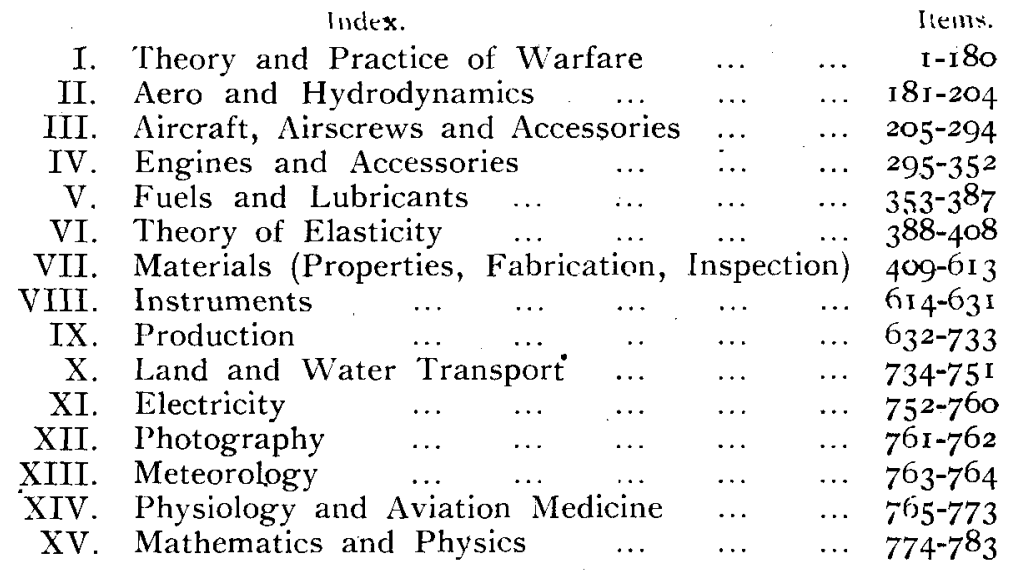

\section{Theory and Practice of Warfare.}

Training and General Strategy.

\begin{tabular}{ccc}
$\begin{array}{c}\text { ITEM } \\
\text { No. }\end{array}$ & \multicolumn{2}{c}{ R.T.P. } \\
I & 9828 & U.S.A. \\
2 & 9877 & U.S.A. \\
3 & 9887 & U.S.A. \\
4 & 9890 & U.S.A. \\
5 & 10065 & U.S.A. \\
& & \\
6 & 10130 & G.B. ... \\
7 & .10149 & Africa \\
8 & 10150 & U.S.S.R. \\
\hline 9 & 10153 & G.B. ... \\
\hline 10 & 10250 & U.S.A
\end{tabular}

TITLE AND JOURNAL.

... Office of War Information on U.S. Aircraft. (R. H. Wood, Am. Av., Vol. 6, No. II, I/I I/42, pp. I and 16.$)$

... Popular Names of the U.S. Military Aircraft. (Am. Av., Vol. 6, No. I6, I5/1/43, p. 2o.)

... The Master Weapon-The Aeroplane Sets the Pace in Modern Tactics. (J. F. C. Fuller, Army Ordnance, Vol. 22, No. I 34, Sept.-Oct.; 1942.)

Attack on Japan. (H. Nickerson, Army Ordnance, Vol. 22, No. 134, Sept.-Oct., I942, pp. 283-286.) Organisation and Work of the Army Ordnance Department. (T. Lewis, Mech. Eng., Vol. 65, No. 2, Feb., 1943, pp. IOI-104.)

Education in the British Army. (Nature, Vol. I5I, No. $3,833,17 / 4 / 43$, pp. $438-440$.)

Africa as an Air Base. (N. Macmillan, Aeronautics, Vol. 8, No. 2, March, 1943, pp. 28-32.)

Russian Reports on German Air Tactics. (Aeronautics, Vol. 8, No. 2, March, 1943, p. 32.)

Chief of Bomber Command. (Aeronautics, Vol. 8, No. 2, March, 1943, p. 44.)

Will Aircraft Beat the U-Boat? (J. A. Ward, Aero Digest, Vol. 43, No. 3, March, . 1943, pp. I I 4-I I 7.) 
ITHY R.T.P

NO. RIEF.

TITLE AND JOURNAL.

I 10280 U.S.A.

U.S. Army Air Forces Technical Training Centre in Atlantic City. (F. R. Nelson, U.S. Air Services, Vol. 27, No. 12, Dec., I942, pp. 13-I4 and 41.$)$

12 ' 10296 Canada ... Training Chinese Pilots in U.S.A. (G. H. Copeland, Flying, Vol. 32, No. 3, March, 1943, pp. 26-27 and I 14.)

I3 rozor Canada

Helicopters for War? (R. Carter, Flying, Vol. 32, No. 3, March, 1943, pp. $3^{8}$ and i $3^{8 .)}$

1410306 U.S.A.

Observer School at. Brooks Field. ('I. E. Bercaw, Flying, Vol. 32, No. 3, March, 1943, pp. $4^{6-48}$ and $14 \mathrm{I}$.)

I5 ro376 U.S.A. ... Alaska-Russia-China Route Opened. (Aviation, Vol. 41, No. I I, Nov., 1942, p. 256.)

I6 10467 U.S.A.

Sikorsky Helicopter Against Submarines. (Inter. Avia., No. $862,27 / 3 / 43$, pp. 20-2 I.)

I7 I0468 G.B. ...

I8 . 10507 U.S.A.

I9 $\quad \log ^{\mathrm{I}} \quad$ G.B. ...

Hurricanes as Tank Busters. - (Inter. Avia., No. $862,27 / 3 / 43$, p. 21 .)

Air Force Targets-Ruhr Dams and Water Power Stations. (Engineer, Vol. 175, No. 4,558, 21/5/43, pp. 405-408.)

${ }_{25}$ Years of Progress in the R.A.F. (Trade and Engineering Times, Vol. 52, No. 95, April, 1943, p. 33.)

$20 \quad$ I0593 Canada

Pre-Flight Training in Canada. (B. Keith, Flying, Vol. 32, No. 5, May, 1943, pp. 48-50 and I $46-15 \mathrm{C}$ )

Design and Equipment of Military Aircraft.

2 I 9809 U.S.A. $\quad \ldots$ Polaroid Windscreen and Goggles for Blind Flying Training. (Am. Av., Vol. 6, No. 19, I/3/43, p. 3o.)

229810 U.S.A. A. Seven-Man Rubber Boat for Use on the B-17. (Am. Av., Vol. 6, No. 19, 1/3/43, p. 48.)

$23 \quad 9^{81} 3$ U.S.A.

Portable Metal Runway Laid by Royal Engineers on N. African Airfield (Photo). (Am. Av., Vol. 6, No. 19, 1/3/43, p. 22.)

249880 U.S.A. ‥ New Aircraft Tank Cap. (Am. Av., Vol. 6, No. 16, I $5 / 1 / 43$, p. 47.$)$

259973 U.S.A. _. Conversion of Bombers into Freighters. (W. M. Sheehan, Am. Av., Vol. 6, No. 20, I5/3/43, pp. I 4 and 32.)

269986 Germany

Dornier 2 7 .E Examination of De-Icing Equipment. (Commercial Aviation, Vol. 4, No. 12, Dec., 1942, pp. 42-44.)

27 IOI5I Germany ... Junkers Aircraft-Genesis and Development of the Stuka. (Aeronautics, Vol. 8, No. 2, March, I943, pp. 34-4I and 61.)

2810248 U.S.A. $\quad \ldots \quad$ Nose of the Douglas B-I9 (Photo). (Aero Digest, Vol. 42, No. 3, March, 1943, p. I I 2.)

$291035^{6}$ U.S.A.

Leading Edge Centre Section of the VoughtSikorsky V.S.-44-A.C. (Design'Detail). (Aviation, Vol.. 4I, No. I I, Nov., I942, p. I54.) 


\begin{tabular}{ccc} 
ITEM & \multicolumn{2}{c}{ R.T.P. } \\
Yo. & RE. \\
30 & 10357 & U.S.A. \\
31 & $1035^{8}$ & U.S.A. \\
& & \\
32 & 10360 & U.S.A. \\
33 & 10361 & U.S.A. \\
34 & 10362 & U.S.A. \\
& & \\
35 & 10363 & U.S.A. \\
36 & 10364 & U.S.A. \\
& & \\
37 & $1057^{\circ}$ & Germany \\
38 & 10599 & U.S.A.
\end{tabular}

$39 \quad 9^{802} \quad$ G.B.

9854 G.B. $\ldots$

410986 G.B. . .

$4^{2}$ Iо3근.S U.S.

$43 \quad 10368$ U.S.A.

$44 \quad 10473$ U.S.A.

$45 \quad 10591$ Canada

$46 \quad 9869$ U.S.A.

479889 U.S.A.

$48 \quad 10339$ U.S.A.
TITLE AND JOURNAL.

Details of Retractable Nose Wheel of the Tricycle Landing Gear of the Douglas C-54. (Aviation, Vol. 4I, No. I I, Nov., 1942, p. I 54.)

Now Type Diving Brake Fitted to Dornier 217 and Detachable Tail Unit (Design Details). (Aviation, Vol. 4I, No. I I, Nov., r942, p. r 54.)

Details of Elevator Control Torque Tube of the Vought-Sikorsky V.S.-44-A. (Aviation, Vol. 41,

No. I I, Nov., 1942, p. I 57.)
Retracting Landing Gear of Focke-Wulf 190 (Design Details). (Aviation, Vol. 4I, No. II, Nov., 1942, p. 157 .)

.. Hull-Tail Frame Construction of the VoughtSikorsky V.S.-44-A (Design Details). (Aviation,

'Vol. 4i, No. I I, Nov., 1942, p. I58.)

Douglas A-2o Fuselage (Design Details). (Aviation, Vol. 4I, No. II, Nov., 1942, p. I58.)

... Tail Wheel Installation of the North American Trainer (Design Details). (Aviation, Vol. 4I, No. I I, Nov., 1942, p. I 58 .)

Test and Development Work on the Do. 217. (W. Zuerl, Motor Schau., Vol. 7, No. 3, March, 1943, pp. 95-97.)

Novel Ski-Wheel Gear on North American Texan (AT-6, S.N.J.) (Photo). (Flying, Vol. 32, No. 5, May, 1943, p. 7o.)

Armament.

Battle of Fire Power vs: Fire Power. (Canadian Aviation, Vol. 16, No. I, Jan., I943, pp. 55, 83-8.)

.. Disposition of Fighter Armament-Firing Error Due to Installation in the Wings. (D. I. Husk, Airc. Eng., Vol. I 5, No. I70, April, I943, pp. 94-97.)

... Enemy Aeroplane Weapons, 1939-1943. (Airc. Eng., Vol. 15, No. 170, April, 1943, pp. 100-102.)

.. U.S. Pouer Turréts. (Flying, Vol. 32, No. 3 , March, 1943, pp. 52-53.)

... Fire Power Details of Nazi Planes. (Aviation, Vol. 41, No. r. I, Nov., I 942 , pp. 200-2 Ir.)

The Fire Power of the Bell P-39 Airacobra (Photo graph). (Inter. Avia., Vol. 6, No. 21, I/4/23, p. I7.)

.. Fire Power of Allied and. Axis Planes (Chart). (Flying, Vol. 32, No. 5, May, 1943, p. 44.)

Explosives, Ballistics.

.. New Low-Level Bombsight (Photograph). (Am. Av., Vol. 6, No: $17,1 / 2 / 43$, p. 48.)

Unexploded Bombs (Disposal and Neutralization). (F. J. Kane, Army Ordnance, Vol. 22, No. 134, Sept.-Oct., 1942, pp. 277-282.)

... Low-Level Bombsight. (Canadian Av., Vol. I5, No. 12, Dec., 1942, p. 160.) 
ITEM

No.

49

50 10503 U.S.A.

$5^{\text {I }} \quad$ I0532 Germany

$5^{2} \quad 10533$ Germany

$53 \quad$ ro534 Germany

$54 \quad 10537$ Germany
TITLE AND JOURNAL.

Details of Bomb Racks of Twin-Engine Manchester Bomber. (Aviation, Vol. 4r, No. I I, Nov., I942, p. I 54.)

Bomb Scoring by Seismograph (Location of Bomb Impact by Seismograph). (Sci. Am., Vol. I68, No. 3, March, r943, pp. I 28-1 29.)

Approximation to Field Artillery Trajectories by Means of Parabolas. (W. Haist, Z.G.S.S., Vol. 38, No. 3, March, 1943, pp. 45-47.)

The Artificial Drying of Explosives. (E. Glucklich, Z.G.S.S., Vol. 38, No. 3, March, 1943, pp. 48-5o.)

Internal Ballistics-Wffect of Gas Inertia with Special Reference to the Acceleration of Charge. (H. Pfrien, Z.G.S.S., Vol. 38, No. 2, Feb., 1943, pp. $21-25$.

Influence of Target Supports on Effects of Projectile. (M. Gercke, Z.G.S.S., Vol. 38, No. 2, Feb., I943, pp. 29-32.)

Military Types Aircraft (British).

559834 G.B.

British Lancaster (Photo). I I, I/ I I/42, p. I6.)

$5^{6} \quad 9^{8} 37 \quad$ G. B. ...

Miles' Master III Trainer (Photo). (Am. Av., Vol. 6, No. II, I $/$ I $/ 42$, p. I9.)

$57 \quad 9963 \quad$ G.B. $\quad$..

Hauker Typhoon Single-Seater Fighter. (Engineer, Vol. I 75 , No. $4,556,7 / 5 / 43$, p. 366 .)
$5^{8} \quad 9964$ G.B. . .

$59 \mathbf{1 0 2 3 9}$ G.B. ...

$60 \quad 10297$ Canada

6I IO3II G.B.

$62 \operatorname{lo} 327$ G.B. ...

63 I0456 G.B. ...

64 I055० G.B. ...

$65 \quad$ I0554 G.B. ...

The De Havilland $\cdot$ Mosquito. (Engineer, Vol. I75, No. $4,55^{6}, 7 / 5 / 43$, pp. 373-375.)

The Mosquito and the Hawker Typhoon Aircraft. (Engineering, Vol. I 55, No. 4,055, 14/5/43, p. $3^{8} 5$.)

The Hurricane. (Sir F. S. Spriggs, Flying, Vol. 32, No. 3, March, 1943, pp. 28-29 and I 20-1 22.)

Handley Page "Hampden" (Silhouette). (Flying, Vol. 32, No. 3, March, 1943, p. 51.)

Anson $V$ Made of Moulded Plywood. (Canadian Av., Vol. I5, No. 12, Dec., 1942, pp. 96-98.)

Miles' $M$. 18 and $M$. 28 Trainers. (Inter. Avia., No. $862,27 / 3 / 43$, p. I 2.)

Hawker Typhoon. (Trade and Engineering Times, Vol. 52, No. 95, April, 1943, p. 32.)

The Whirlwind as a Fighter Bomber. (Trade and Engineering Times, Vol. 52, No. 95, April, 1943, p. $3^{6 .)}$

Military Types Aircraft (U.S.S.R.).

6610454 U.S.S.R. ‥ L.A.G.G.-3 Fighter. (Inter. Avia., No. 862,

67. 10455 U.S.S.R. $27 / 3 / 43$, pp. I and Io-r r.)

P.E.-2 Twin-Engined Bomber. (Inter. Avia., No. 862, 27/3/43, pp. I I-I 2.)

Military Types Aircraft (U.S.A. and Mexico).

68 Iooo4 U.S.A. $\quad \ldots \quad$ New Curtiss Dive-Bomber (Photograph). (Autom. Ind., Vol. 88, No. $4,15 / 2 / 43$, p. 54.) 
TITLES AND REFERFNCES OF ARTICLES AND PAPERS.

ITEM R.T.P

No. REF.

$69 \quad 10062$ U.S.A.

7o 10076 U.S.A.

71 10078 U.S.A.

721008 I U.S.A.

73 ror 48 U.S.A:

$74 \operatorname{ror} 54$ U.S.A.

$75 \quad 10227$ U.S.A.

76 I025I Mexico

$77 \quad 10262$ U.S.A.

$78 \quad$ Iо305 $_{3}$ U.S.A.

79 Iо307 U.S.A.

$80 \quad 10309$ U.S.A.

81 Io310 U.S.A.

82 Iо3' 4 U.S.A.

83 Iо3I5 U.S.A.

84 10328 U.S.A.

$85 \quad 10338$ U.S.A.

86 IO34I U.S.A.

87 I0366 U.S.A.

$88 \quad 10379$ U.S.A.

8910404 U.S.A.
TITLE AND JOURNAL.

Curtiss Dive Bombers (I 4 Years of Development). (Curtiss Flyleaf, Vol. 25, No. 4, Sept.-Oct., 1942, pp. IO-I3.)

The "Sentinel" for Army Co-operative Worli (Photograph) (Built by the Vultee Aircraft Inc.).

(Mech. Eng., Vol. 65, No. I, Jan., I943, p. 5 r.)

Curtiss S.B. 2 C-I-Helldiver (Photograph). (Curtiss Flyleaf, Vol. 25, No. 5, Nov.-Dec., I942, p. 6.)

Curtiss Wright Aircraft, 1943 (Photograph). (Curtiss Flyleaf, Vol. 25, No. 5, Nov.-Dec., I942,

pp. I6-17.)
Vought-Sikorsky Helicopter (with Pontoons, Photograph). (Aeronautics, Vol. 8, No. 2, March, 1943, p. 73.)

Lockheed Vega Ventura. (Aeronautics, Vol. 8, No. 2, March, 1943, pp. 48-49.)

Thunderbolt Fighter Aircraft. (Engineer, Vol. I75, No. $4,557,14 / 5 / 43$, p. 398.)

Mexican Plastic Plywood Light Plane "Tezinthan" (Photograph). (Aero Digest, Vol. 42, No. 3, March, 1943, p. I 18.$)$

The Bell "Airacobra", (Including Sketches of Wing Panel, etc.). (Aero Digest, Vol. 42, No. 3 , March, 1943, pp. 256-257.)

High Wing Curtiss O-52 (Photograph). (Flying, Vol. 32, No. 3, March, I943, p. 46.)

Boeing P.T. I7 (Stearman) Trainer (Photograph). (Flying, Vol. 32, No. 3, March, 1943, p. 48.)

North American " Mustang" (P.S. I) (Photograph). (Flying, Vol. 32, No. 3, March, I943, p. 5o.)

.. Curtiss "Helldiver" (S.B.2C.) (Silhouette). (Flying, Vol. 32, No. 3, March, 1943, p. 5c.)

The Lockheed "Hudson", Trainer AT-I8 (Photograph). (Flying, Vol. 32, No. 3, March, r943, p. 6o.)

Vultoe Vengeance (A-3I) Dive Bomber (Photograph). (Flying, Vol. 32, No. 3, March, I943, p. 6I.)

North American B-25 Bomber (Photo). (Canadian Av., Vol. 15, No. 12, Dec., 1942, p. 92.)

Stimson-Vega "Sentinel"' and "Reliant" (Liaison and Trainer) (Photo). (Canadian Aviation, Vol. I 5, No. I 2, Dec., I942, p. I6o.)

Twin-Engine Planes to Train Bomber Crews, $A T$ Series (Silhouettes). (Aviation, Vol. 4I, No. I I, Nov., 1942, p. Ioo.)

Vought-Sikorsky $\mathrm{F}_{4} \mathrm{U}$ Corsair (Photograph). (Aviation, Vol. 4I, No. I I, Nov., 1942, p. I8g.)

American Aircraft and Their Combat Performance. (Aviation, Vol. 4I, No. I I, Nov., 1942, pp. 92-93. and $275-276$.

Sikorsky Helicopter (Photograph). (Autom. Ind., Vol. 88, No. $5, \mathrm{i} / 3 / 43$, p. 42 .) 
ITEM R.T.P.

No. REF.

90 Io4r8 U.S.A.

$9^{1}$ 10457 U.S.A.

$9^{2}$ I0459 U.S.A.

93 I 0460 U.S.A.

94 I0462 U.S.A.

9510463 U.S.A.

97 ro47I U.S.A.

98 I0474 U.S.A.

9910562 U.S.A.

Ioo 10589 U.S.A.

Germany

I02 10598 U.S.A. and G.B...
96.10464 U.S.A.

IOI I0597 U.S.A./

TITLE AND JOURNAL.

Plywood Primary Trainers for Army, Ryan P.T.-25. (Autom. Ind., Vol. 88, No. I, 1/1/43, pp. 24-25 and 54.)

Boeing ${ }_{17} E$ and ${ }_{17} F$ (Fortress II). (Inter. Avia., No. $862,27 / 3 / 43$, pp. 14-1 5.)

New Version of Douglas DB-7 (Havoc and Boston). (Inter. Avia., No. 862, 27/3/43, pp. I5-16.)

Bell P-39 Airacobra. (Inter. Avia., No. 862, 27/3/43, p. 17.)

Martin 167 Maryland Light Bomber. (Inter. Avia., No. $862,27 / 3 / 43$, p. I6.)

Curtiss Helldiver. (Inter. Avia., No. 862, 27/3/43, pp. I and i6.)

Vultee Vengeance Dive Bomber. (Inter. Avia., No. $862,27 / 3 / 43$, p. I6.)

Boeing A:T.-15 Advanced Trainer. (Inter. Avia., No. $862,27 / 3 / 43$, p. I.)

Noordwyn U.C.-64 (Photograph). (American Aviation, Vol. 6, No. 21, p. 52.)

Curtiss A-25 U.S. Army Dive Bomber (Photo). (U.S. Air Services, Vol. 28, No. 2, Feb., 1943, p. $3^{6 .)}$

Lockheed Lightnings $\left(P_{-3} 8\right)$ in Africa. (W. J. Hoelle, Flying, Vol. $3^{2}$, No. 5, May, 1943, pp. 24-25 and 136. )

North American Mustang, Focke-Wulf igo and Me. Io9 (Silhouettes). (Flying, Vol. $3^{2}$, No. 5, May, 1943, p. 67.)

Curtiss "Warhawk" and Avro Lancaster (Silhouettes). (Flying; Vol. 32, No. 5, May, 1943, p. 68.)

Io3 9806 U.S.A.

Fairchild Plyuood Advanced Trainer. (Canadian Aviation, Vo!. 16, No. I, Jan., 1943, p. 104.)

Curtiss A-25. Army "Helldiver" (Photo). (Am. Av., Vol. 6, No. 19, 1/3/43, p. 46.)

Vought-Sikorsky Helicopter V.S.-300. (Am. Av., Vol. 6, No. 19, 1/3/43, p. 44.)

Inspecting Liberator $(B-24)$ Heavy Bombers. (Autom. Ind., Vol. 88, No. 2, 15/1/43, pp. 40-41.)

I07 9826 U.S.A.

$\leftarrow 08 \quad 9829$ U.S.A.

$109983 \mathrm{I} \quad$ U.S.A.

I ro 9833 U.S.A.

I I 9847 U.S.A.

I 29857 U.S.A.

II3 9883 U.S:A.
The Consolidated $\mathrm{C}-87$ (Photograph). (Autom. Ind., Vol. 88 , No. 2, I 5/1/43, p. 48.)

Flying Fortress (Photo). (Am. Av., Vol. 6, No. I I, I/ I I/42, p. 8.)

North American P-5 " Mustang" (Photo). (Am. Av., Vol. 6, No. I I, I/I I/42, p. I3.)

Martin B-26 (Photo). (Am. Av., Vol. 6, No. I I, I/I I $/ 42$, p. I6.)

Ryan Plyuood Trainer (Photo). (Am. Av., Vol. 6, No. I I, I $/$ I I $/ 4^{2}$, p. 48 .)

New R.A.F. Tupes-The Martin Maryland, Martin Marauder, Martin Baltimore. (Airc. Eng., Vol. 15, No. 170, April, 1943, pp. 103-105 and 114.)

Grumman T.B.F.-I Avenger (Photograph). (Am. Av., Vol. 6, No. $16,15 / 1 / 43$, p. 8o.) 


\begin{tabular}{|c|c|c|}
\hline $\begin{array}{l}\text { ITEM } \\
\text { No. }\end{array}$ & \multicolumn{2}{|c|}{$\begin{array}{l}\text { R.T.P. } \\
\text { REF. }\end{array}$} \\
\hline I 14 & 9894 & U.S.A. \\
\hline $\mathbf{I}_{5}$ & 9974 & U.S.A. \\
\hline 116 & 9978 & U.S.A. \\
\hline I 17 & 9989 & U.S.A. \\
\hline I 18 & $999^{I}$ & U.S.A. \\
\hline 119 & 9993 & U.S.A. \\
\hline
\end{tabular}

TITLE AND Journal.
... American Maryland Bomber in Egypt (Photo). (Army Ordnance, Vol. 22, No. 134, Sept.-Oct., 1942, p. 302.)

Stimson L-S Vultee's Liaison Plane (Photograph). (Am. Av., Vol. 6, No. 20, I 5/3/43, p. I9.)

Curtiss-Wright's Scout Observation Plane $\mathrm{SO}_{3} \mathrm{C}-\mathrm{I}$, The Seamew (Photograph). (Am. Av., Vol. 6,

No. 20, 15/3/43, p. 27.).
P-47 Thunderbolt. (Photograph). (Commercial Avia-

tion, Vol. 4, No. I2, Dec., r942, p. 86.)
New Canso (Catalina) (Photograph). (Commercial Aviation, Vol. 4, No. I2, Dec., I942, p. 9o.)

Fairchild Plyuood Trainer. (Commercial Aviation, Vol. 4, No. 12, Dec., 1942, p. 102.)

Military Types Aircraft (Germany).
$120 \quad 9832$ Germany $\quad \ldots$ German Focke-Wulf 190 (Photo). (Am. Av., Vol.

I2I 9938 Germany $\quad \ldots \quad$ Messerschmitt IIo, Details of Germany's Mass Produced Fighter. (J. E. Thompson, Paper Presented by the S.A.W.E.)

122 IOI47 Germany

New German and Russian Aircraft on Russian \& U.S.S.R. ... Front Me. I I5 and Heinkel ir7. (Aeronautics, Vol. 8, No. 2, March, 1943, p. 73.)

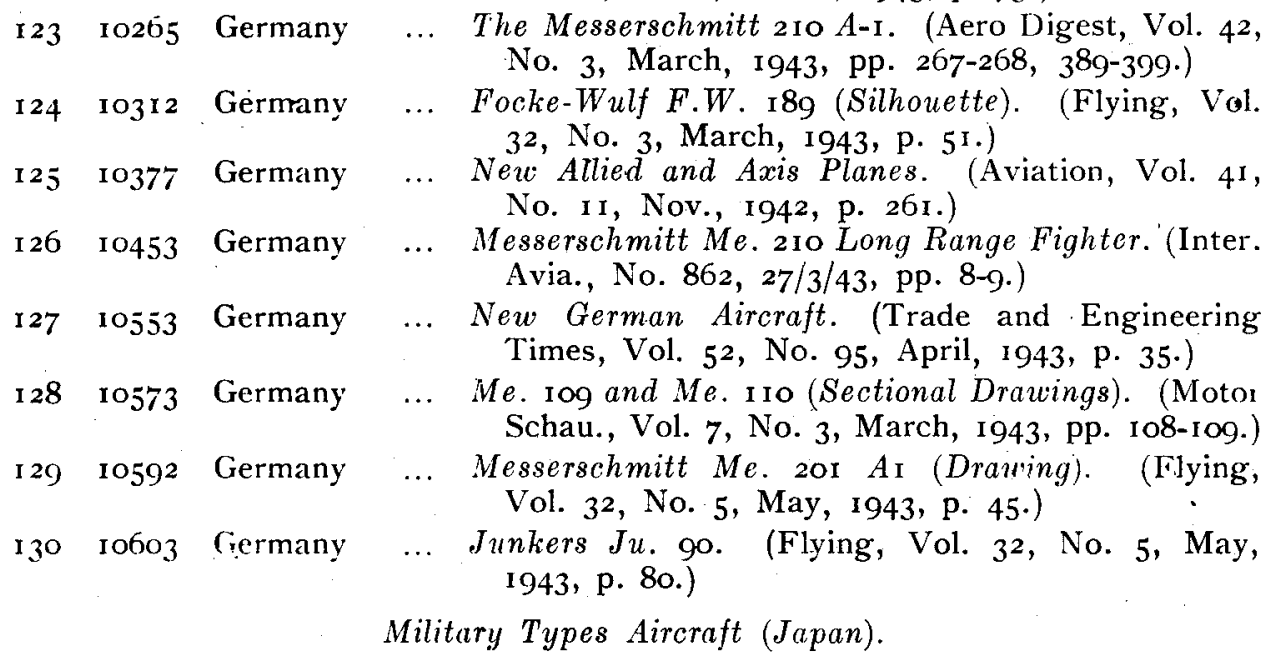

I31 9830 Japan $\quad \ldots$ Japanese OO Fighter (Photo). (Am. Av., Vol. 6, No. I I, I $/$ I I $/ 42$, p. Io.)

1329896 Germany ('haracteristics of Enemy Aircraft (German and and Japan ... Japanese). (Army Ordnance, Vol. 22, No. I34, Sept.-Oct., I942, pp. 32 1-322.)

13310308 Japan ... Mitșubishi Zero (Revised Photograph). (Flying, Vol. 32, No. 3, March, 1943, p. 49.)

Military Types Aircraft (Italy).

$134{ }_{10084}$ Italy ... ... Piaggio P. ro8 Long Range Bomber (Photo). (Luftwissen, Vol. 1o, No. 3, March, 1943, p. 68.) 
ITEM No.

I 35

13

137

${ }_{138} \quad 9878 \quad$ G.B.

14010080 U.S.A.

I4I 10082 U.S.A.

14210249 U.S.A.

I 43 IO300 U.S.A

$1441033^{\circ}$ U.S.A

14610423 U.S.A.

$1471045^{8}$ U.S.A.

$148 \quad 1046$ I.S.A.

149 10469 G.B. ...

$15^{\circ} 1047^{\circ}$ Germany

I $51 \quad 1055^{6}$ U.S.A.

15210561 U.S.A.
13910060 U.S.A.

I45 10405 U.S.A.

\section{Troop Transport and Ambulance Planes.}

TITLE AND JOURNAL.

... Curtiss Caravan C. 76 Transport. (Autom. Ind., Vol. 88, No. 2, I $_{5} / 1 / 43$, pp. 26-27.)

Lockheed Constellation (Photograph) (Am. Av., Vol. 6, No. I7, I $/ 2 / 43$, p. 21.)

The New Lockheed Constellation Four-Engined Transport C-69. (Am. Av., Vol. 6, No. I6, ${ }_{5} / 1 / 43$, pp. 15 and 23 .)

Hydroplane Used by the R.A.F. for Rescue Work (Photograph). (Am. Av., Vol. 6, No. 16, 15/1/43, p. 26.)

Curtiss Caravan Transport. (Curtiss Flyleaf, Vol. 25, No. 4, Sept.-Oct., 1942, pp. 3-7.)

Curtiss Commando Twin-Engine Transport (Photograph of Spacious Fuselage). (Curtiss Flyleaf, Vol. 25, No. 5, Nov.-Dec., 1942, pp. 8-1o.)

Gurtiss Caravan C.76 Wooden Cargo Transport. (Curtiss Flyleaf, Vol. 25, No. 5, Nov.-Dec., 1942, pp. I 8-19.)

Douglas "Sky Train" Military Transport (Photograph). (Aero Digest, Vol. 42, No. 3, March, 1943, p. II3.)

Lockheed Constellation. (P. Pierce, Flying, Vol. 32, No. 3, March, 1943, pp. 35 and 1 26.)

Consolidated C.87 Army Transport (Photo). (Canadian Av., Vol. I5, No. 12, Dec. I2, p. 164.)

Consolidated $\mathrm{P}_{4} \mathrm{Y}$-1 Flying Boat (Model 3I) (Photograph). (Autom. Ind., Vol. 88, No. 5, $1 / 3 / 43$, p. 43.)

Air Ambulance for Navy Fliers (Piper) (Photograph). (Autom. Ind., Vol. 88, No. I, I/1/43, p. $5^{\circ}$.)

Consolidated $3^{\mathrm{I}}$ Flying Boat (Military Version). (Inter. Avia., No. 852, 27/3/43, pp. I and 15. )

Douglas Transports $\left(C_{47}, C_{53}, C_{54}\right)$. (Inter. Avia., No. $862,27 / 3 / 43$, p. 16.)

Armstrong Whitworth Ensign (Transport Plane). (Inter. Avia - No. 862, 27/3/43, p. 28.)

Messerschmitt Me. 323 Transport (Photo). (Inter. Avia., No. $862,27 / 3 / 43$, p. I.)

America's Biggest Transport Plane the "Constellation" (Photo). (U.S. Air Services, Vol. 28, No. 2, Feb., 1943, pp. 16-17 and 44.)

Curtiss "Caravan" All Wood Transport (Photo). (U.S. Air Services, Vol. 28, No. 2, Feb., I943, p. 40.)

Gliders.

$153 \quad 978 \mathrm{I}$ U.S.A.

Waco Troop-Carrying Glider (Photo). (Autom. Ind., Vol. 87 , No. 5 , I/9/42, p. 52.)

$154 \quad 9782$ U.S.A.
The, C.G. 4a 15-Seater Glider Used by Army Air Forces (Photograph). (Autom. Ind., Vol. 87, No. $5,1 / 9 / 42$, p. $5^{8}$.) 


\begin{tabular}{ccc} 
ITEM & \multicolumn{2}{c}{ R.T.P. } \\
No. & REF. \\
155 & 9866 & U.S.A. \\
156 & 10074 & U.S.A. \\
157 & 10145 & France \\
158 & 10278 & U.S.A. \\
& & \\
159 & 10465 & U.S.A. \\
160 & 10472 & U.S.A. \\
161 & 10557 & U.S.A.
\end{tabular}

1629804 G.B. ...

$\begin{array}{lrr}163 & 9867 & \text { U.S.A. } \\ 164 & 9893 & \text { U.S.A. } \\ 165 & 10079 & \text { U.S.A. } \\ 166 & 10260 & \text { U.S.A. } \\ & & \\ 167 & 10279 & \text { U.S.A. } \\ & & \\ 168 & 10304 & \text { U.S.A. } \\ 169 & 10367 & \text { U.S.A. } \\ & & \\ 170 & 10373 & \text { U.S.A. } \\ 171 & 10564 & \text { Germany } \\ 172 & 10590 & \text { Canada } \\ 173 & 10601 & \text { U.S.A. }\end{array}$

TITLE AND JOURNAL.

Waco C.G.-4 Glider Inloading Jeep (Photograph). (Am. Av., Vol. 6, No. 17, 1/2/43, p. 28.)

Cargo Glider Pick-Up. (R. C. du Pont, Mech. Eng., Vol. 65, No. I, Jan., 1943, pp. 35-39.)

French Glider S.O.P.-1. (Aeronautics, Vol. 8, No. 2, March, 1943, p. 59.)

The New Boeing Glider C.G.-4 (Photograph). (U.S. Air Services, Vol. 27, No. 12, Dec., 1942, p. 17.)

Seaworthy Troop-Carrying Glider Bristol XLQ-1. (Inter. Avia., No. 862, 27/3/43, pp. I and 17. )

U.S. Navy's Seaplane Glider XLRQ-I. (American Aviation, Vol. 6, No. $21,1 / 4 / 43$, p. 16.)

The Glider in War and Peace. (R. S. Findley, U.S. Air Services, Vol. 28, No. 2, Feb., 1943, pp. 24 and 44.)

Fleet Air Arm.

"Seãfire" Taking-off from Aircraft Carrier (Photo). (Canadian Aviation, Vol. 16, No. 1, Jan., 1943, p. 64.)

Naval Air Transport Service. (Am. Av., Vol. 6, No. I $7,1 / 2 / 43$, pp. 18 and 28 .)

Wings for the Navy (Photographs of Representative American Naval Aircraft). (Army Ordnance, Vol. 22, No. I34, Sept.-Oct., I942, pp. 293-300.)

Curtiss S.O. 3 C-1 Seagull (Photograph). (Curtiss Flyleaf, Vol. 25, No. 5, Nov.-Dec., 1942, p. 6.) Curtiss “Seagull"' (S.O. 3 C-I) Scout Observation Plane for Fleet Air Arm (Photograph). (Aero Digest, Vol. 42, No. 3, March, I943, p. 242.)

The Brewster Navy "Buccaneer " (Photograph).

(U.S. Air Services, Vol. 27, No. I2, Dec., I942, p. 32.)

U.S. Aircraft Carriers. (F. Tupper, Flying, Vol. 32, No. 3, March, 1943, pp. 42-44 and 1 39.)

U.S. Navy K Type Blimp for Naval Coastal Patrol.

(E. H. Forbes, Aviation, Vol. 4r, No. I I, Nov., 1942, pp. 197-199.)

S.O.R.-ICombat Plane for U.S. Navy (Ryan). (Aviation, Vol. 4I, No. I I, Nov., I942, p. 25I.) Early. Types of German. U Boats. (Motor Schau., Vol. 7, No. 2, Feb., 1943, pp. 46-48.)

Aircraft Carriers. (B. Gruenwald, Flying, Vol.'32, No. 5, May, 1943, pp. 39-4I.)

Naval Version of Vega "Ventura" (PV-1). (Flying, Vol. 32, No. 5, May, 1943, p. 7 I.)

A.R.P. and A.A.

1749886 U.S.A.

I ${ }_{5} \mathrm{~mm}$. Howitzer on Self-Propelled Armoured Mount (Photo). (Army Ordnance, V'ol. 22, No. I34, Sept.-Oct., 1942, p. 265.)

I75 9892 U.S.A.
Air Raid Defence. (G. J. B. Fisher, Army Ordnance,

Vol. 22, No. 134, Sept.-Oct., I942, pp. 290-292.) 
ITHM

No.

I76 9897. U.S.A.

$177 \quad 9898 \quad$ U.S.A.

${ }_{178} \quad{ }_{102} 3^{6} \quad$ G.B. $\ldots$

179 I0244 U.S.A.

I80 Io33 I Canada

I81 10109 Holland

I82 Ior79 Germany

$183 \quad \mathrm{IO}_{2} \mathrm{O}$ Germany

I87 10560 U.S.A.
TITLE AND JOURNAL.

.. Dustproof Cover for $40 \mathrm{~mm}$. Anti-Aircraft Gun (Photo). (Army Ordnance, Vol. 22, No. I34, Sept.-Oct., 1942,.p. 317.)

Covers for ${ }_{155} \mathrm{~mm}$. and $105 \mathrm{~mm}$. Howitzers (Photo). (Army Ordnance, Vol. 22, No. 134, Sept.-Oct., 1942, pp. 318-319.)

A Method of Demonstrating the Identification of War Gases. (H. W. Keenan and R. S. Law, Chem. and Industry, Vol. 62, No. 20; 15/5/43, pp. 182-I 84.)

Protection of Civilians from Vesicant Agents. (T. F. Bradley and others, Ind. Eng. and Chem. (News Ed.), Vol. 21, No. 6, March, 1943, pp. 373-375.)

Canada's Aircraft Detection Corps (Spotters).

(Canadian Av., Vol. I5, No. 12, Dec., 1942, p. I64.)

\section{Aero and Hydrodynamics.}

General. Aerofoil Theory.

.. Effect of a Rotating Cylinder Placed in the Nose of an Aerofoil on its Aerodynamic Characteristics.

(E. B. Wolff and C. Koning, Rykstudiedienst

Voor Luchvaart, Vol. 3, 1925, Report 96a;

Vol. 4, 1927, Reports 98a, 105a and 130a.)

Aerodynamic Force on a Harmonically Vibrating

Wing in a Supersonic Field of Flow (Tuo-Dimensional Case). (S. Borbely, Z.A.M.M., Vol. 22, No. 4, Aug., I942, pp. 190-205.)

The Theory of the Lifting Wing. (I. Nikuradse and E. Mohr, L.F.F., Vol. 20, No. 2, 27/2/43, pp. 48-56.)

Glenn Martin Graphic Solution of the Flutter Problem. (U.S. Air Services, Vol. 28, No. 2, Feb., 1943, p. 33.)

Laminar and Turbulent Flow.

$.188 \quad 10476$ U.S.A.

... Heat Transfer and Pressure Drop in Annuli. (E. S. Davis, A.S.M.E. Preprint, April 26-28, 1943, pp. I-5.)

Wind Tunnels and Research.

I9r Iooo8 U.S.A. $\quad \ldots \quad$ Survey of Papers Presented at the Eleventh Annual Meeting of the Institute of Aeronautical Sciences. (Autom. Ind., Vol. 88, No. 4, I 5/2/43, pp. 24-26, 42 and 78.$)$

$1922 \quad 10083$ U.S.A. $\quad \ldots \quad$ Curtiss 7oo Miles per Hour Wind Tunnel (including Cutaway Perspective Drawing). (Curtiss Flyleaf, Vol. 25, No. 5, Nov.-Dec., 1942, pp. 22-23.)

I93 roż76 U.S.A. _. New U.S.A. Wind Tunnels. (Aero Digest, Vol. 42, No. 3, March, 1943, p. 428.)

194 ro374 U.S.A. - ... N.A.C.A.'s New Research Programme. (Aviation, Vol. 4I, No. I I, Nov., I942, p. 25I.)

I95 I0375 U.S.A. ... New North American Wind Tunnel. (Aviation, Vol. 4I, No. I I, Nov., I942, p. 252.) 


\begin{tabular}{rrr} 
ITEM & \multicolumn{2}{l}{ R.T.P. } \\
No. & REF. \\
I96 & 9946 & U.S.A. \\
I97 & 10028 & U.S.A. \\
& & \\
198 & 10035 & U.S.A. \\
& & \\
199 & Ior 33 & G.B. ... \\
200 & 10178 & Germany
\end{tabular}

$2 \mathrm{OI} \mathrm{IO}_{2} \mathrm{O}$ Germany

$202 \quad 10238$ G.B. ...

20310026 U.S.A.

2041003 I U.S.A.
General Hydrodymamics.

TITLE AND JOURNAL.

... Some Aspects of Water Presented by the S.A.W.E.) Performance and Selection of Mechanical: Draft Cooling Towers. (J. Lichtenstein, A.S.M.E. Preprint, April 26-28, I943.)

Graphical Solution of Fluid Friction Function Problem (Discussion). (E. S. Dennison, J. App. Mech., Vol. Io, No. I, March, 1943, pp. 5I-52.)

Theory of the Sea Waves. (P. J. H. Unna, Nature, Vol. I 5 I, No. $3,834,24 / 4 / 43$, pp. 479-48o.)

Field of Flow Due to Slow Rotation of Two Eccentric Cylinders in a Viscous Fluid. (W. Muller, Z.A.M.M., Vol. 22, No. 4, Aug., 1942, pp. I77-189:)

Influence of Cross-Sectional Area of the Surge Chamber on the Fluctuation of the Water Level, During Inflow; Control of Hydraulic Turbines. (W. Richter, Ing. Archiv., Vol. I3, No. 6, I943, pp. 33 I-342.)

Breakwaters (Contd.). (R. R. Minikin, Engineering, Vol. I 55, No. 4,035, I4/5/43, pp. $3^{8 \mathrm{r}-382 .)}$

Flow in Tubes and Pipes.

.. Heat Transfer to a Fluid Flowing Periodically at Low Frequencies in a Vertical Tube. (R. C. Martinelli and others, A.S.M.E. Preprint, April 26-28, 1943.)

Relationship Between Reynolds Number and Velocity Distribution in a Pipe. (L. S. Rhodes, ! App. Mech., Vol. Io, No. I, March, 1943, pp. 21-22.)

\section{Aircraft, Airscrews and Accessories.}

Civil Aviation and Air Cargo.

2059815 U.S.A. $\quad$... Freight Transport by Air in Liatin America (Partially Cut by Censor). (J. P. Zandt, Autom. Ind., Vol. 88 , No. 2 , I $5 / 1 / 43$, pp. $24-25,84-85$.)

206 Ioogo Germany ... The First Towed Glider Flights (I9r9-1920). (M. Bohm, Luftwissen, Vol. Io, No. 3, March, I943, pp. 86-87.)

207 I0I 44 G.B. ...

Air Travel-1950. (D. C. Greenwood, Aeronautics, Vol. 8, No. 2, March, 1943, pp. 56-57.)

Commercial Aviation After the War (Review of New Manufacturing Technique). (B. C. Boulton, Aero Digest, Vol. 42, No. 3, March, I943, pp. I I I-I I 3 , I 38 - I 40 and 386-398.)

209 -10269 U.S.A. ... Some Observations on the Post-War Planning of the Aircraft Industry. (S. Siggia, Aeto Digest, Vol. 42, No. 3, March, 1943 , pp. $3^{68}$ and 405-406.)

2 so 10294 Canada $\quad .$. Land̆ Planes or Flying Boats for Cargo? (T. P. Hall, Vol. 32, No. 3, March, I943, pp. 20-2I and I 24.$)$ 
ITENi R.T.P

No. $\quad$ REF.

TITLE AND JOURNAL.

2 I I 10346 U.S.A.

2 I 2 10370 U.S.A.

The Future of Water-Based Planes, VI.. (F. T. Courtney, Aviation, Vol. 4I, No. 11, Nov., 1942, pp. I 22-1 23, 284 and 288.)

$\begin{array}{lll}213 & 10394 & \text { U.S.A. } \\ 214 & 10424 & \text { U.S.A. }\end{array}$

Cargo Planes for World Trade. (G. F. Bauer, Aviation, Vol. 4I, No. II, Nov., 1942, pp. 2 I-2I7 and 280.)

Requirements in Air Cargo Carriers (Symposium of Papers). (Autom. Ind., Vol. 88, No. 5, I/3/43, pp. I 4-I 8.)

Air Cargo Stimulated by Urgencies of War (Article Incomplete). (Autom. Ind., Vol. 88, No. I, I/r/43, pp. 36-37 and 68-72.)

.. Post-War Civil Aviation. (Engineer, Vol. I75, No.

$216^{\circ} 10495$ U.S.A. $\quad \ldots \quad$ Industrial Air Control. (M. Ingles, Sci. Am., Vol. 168, No. 3, March, 1943, pp. Io4-106.)

217 lo509 G.B. ...

Aviation After the War. (Engineer, Vol. I75, No. $4,55^{8}, 2$ I $/ 5 / 43$, p. 4 Io.)

$218 \quad 1055^{2}$ G.B. ...

Post-War Aviation. (Trade and Engineering Times, Vol. 52, No. 95, April, 1943, p. 34.)

Civil and Special Aircraft Types.

2199803 U.S.A. … Lockheed "Excalibur" Commercial Landplane Under Development. (Canadian Aviation, Vol. I6, No. I, Jan., I943, p. 56.)

2209835 U.S.A. . ... New Version of the "Flying IVing" Patented. (D. R. Davis, Am. Av., Vol. 6, No. I I, I/I I/42, p. I6.)

2219983 U.S.A. New Aeronca Cargo Plane (Photograph). (Am. Av., Vol. 6, No. 20, I5/3/43, p. 66.)

222. 10466 France

Mauboussin $M$ 129, $M$ 202, $M$ 300 (Trainers), $M 400$ Cargo Plane. (Inter. Avia., No. 862, $27 / 3 / 43$, p. I9.)

General Design and Construction.

$2239859 \quad$ G.B. ...

Stressed Skin Wooden Construction. (W. Stepniewski, Airc. Eng., Vol. 15, No. I7o, April, I 943 , pp. I IO-I 12 .)

2249928 Germany $\quad$.. Calculation of Power Required for Operating (Variable Camber) Wing Flap. (K. Wolf, Luftwissen, Vol. Io, No. 2, Feb., 1943, pp. 53-57.)

22510152 G.B. ...

The Effect of Compromise on the Design of Aircraft. (Aeronautics, Vol. 8, No. 2, March, 1943, pp. 42-44.)

226 Ior 55 G.B. ... ... Fairey Jet Propulsion Patent. (Aeronautics, Vol. 8, No. 2, March, 1943; p. 5o.)

227 103I7 U.S.A.

$228 \quad 10318$ U.S.A.

The Nose of the Aerofoil. (R. J. Hoffmann, Flying, Vol. 32, No. 3, March, 1943, pp. 63 and 149-15I.)

Steel Fuselage Panels to Replace Aluminium in Vultee Aircraft. (Flying, Vol. 32, No. 3, March, 1943, pp. 9I-92.)

22910343 U.S.A.

Wood Techniques Developed in Glider Construc. tion. (Aviation, Vol. 4I, No. I I, Nov., 1942, pp. I O8-I 1 2.) 
ITEM R.T.P.

No. REF.

$230 \quad$ IO344 U.S.A.

231 IO38 I Germany

$232 \quad 10382$ U.S.S.R.

$233 \quad$ IO $_{53}^{8} \quad$ G.B. $\ldots$

23410604 Canada

2359915 U.S.A. $\quad$... Soc. of Aeron. Weight Engs. Year Book, 1933.

$23^{6} 9916$ U.S.A.

$237 \cdot 9929$ U.S.A.

$238 \quad 9930 \quad$ U.S.A.

$239993^{I}$ U.S.A.

$24^{\circ} \quad 993^{2}$ U.S.A.

24 I 9934 U.S.A.

2429935 U.S.A.

$243993^{6}$ U.S.A.

2449937 U.S.A.

2459939 U.S.A.

$246994^{\circ}$ U.S.A.

247994 I U.S.A.

$248 \quad 9942 \quad$ U.S.A.

2499943 U.S.A.

$25^{\circ} 9944$ U.S.A. (Vol. 3, No. I, I943.)

TITLE AND JOURNAL.

Design Considerations for Plywood Structures. (L. J. Marhoefer, Aviation, Vol. 4I, No. II, Nov., I942, pp. I $14^{-1} 17$ and 340.)

Stressing of Aircraft Wheels. (R.T.P. Translation No. I ,547.) (H. Burkhardt, J. Roy. Aeron. Sci., Vol. 47, No. 389 , May, I943, pp. I33-137.)

Plastics and Their Application to Aircraft Construction. (R.T.P. Translation No. ı,600.) (J. I. Zhibitsky, J. Roy. Aeron. Sci., Vol. 47, No. 389 , May, 1943, pp. 1 38-1 43.).

Stressed Skin Wooden Construction (Contd.). (W. Stepniewski, Airc. Eng., Vol. I 5, No. I7 , May, I 943, pp. I 26- I 3 I.)

Non-Skid Tyre for Icy Landings. (Flying, Vol. 32, No. 5, May, I943, p. I I6.)

Soc. of Aeron. Weight Engs. Year Book, 1942. (Vol. 2, No. I, I942.)

Aeroplane Weight and Balance Control. (S. R. Shatto, Papers Presented by S.A.W.E.)

Aircraft Accessories-A Weighty Problem. (E. C. Roberts, Papers Presented by S.A.W.E.)

Weight Engineer and the Flutter Problem. (P. E. Bisch, Papers Presented by S.A.W.E.)

Relationship of Identification. Numbers to Weight and Cost Control. (D. R. Watson, Papers Presented by S.A.W.E.)

Predetermination of Weight Efficiency. (D. M. Cole, and S. J. Hutchinson, Paper Presented by S.A.W.E.)

A Practical Method for Wing Weight Estimation. (C. R. Engleby, Paper Presented by the S.A.W.E.)

Aircraft Balancing and Centre of Gravity Control. (W. A. Senior, Paper Presented by the S.A.W.E.)

Calculations of Landing Gear and Hydraulic System Weights. (H. W. Adams, Papers Presented by the S.A.W.E.)

Weight Control--Aircraft Design Problems. (E. J. Foley, Paper Presented by the S.A.W.E.)

Will Accessories Impede Our Payload? (L. R. Hackney, Paper Presented by S.A.W.E.)

Weight Predictor. (C. Merrill, Paper Presented by the S.A.W.E.)

Organisation for Weight Control. (J. E. Ayers, Paper Presented by the S.A.W.E.)

Weight Saving by Cleaning Aircraft. (R. E. Sargent, Paper Presented by the S.A.W.E.)

Applications of Psychology to Weight Control. (W. A: Martin, Paper Presented by the S.A.W.E.) 
ITEM R.T.P.

NNo. REF.

TITLE AND JOURNAL.

2519945 U.S.A.

$25^{2} 9949$ U.S.A.

$253 \quad 9798$ U.S.A.

Performance and Testing.

$\begin{array}{rrl}254 & 9913 & \text { Germany } \\ 255 & \text { IOI43 } & \text { G.B. ... } \\ 256 & \text { IO340 } & \text { U.S.A. }\end{array}$

$257 \quad 10425$ U.S.A.

$258 \quad 10596$ Canada

Stratosphere Chamber for Testing Mechanical Parts of Aircraft and Radio. (Metal Progress, Vol. 42, No. 5, Nov., I942, p. 944.)

Operations. (C. Froesch, Paper Presented by the S.A.W.E.)

Weight Economy. (J. E. Ayers, Papers Presented by the S.A.W.E.)

Calculation of Diving Speeds. (E. Kennel, Luftwissen, Vol. 1o, No. 2, Feb., 1943, pp. 51-52.)

Performance Tests on the Junkers 88 A-6. (Aeronautics, Vol. 8, No. 2, March, 1943, pp. 52-53.)

Factors Controlling Aircraft Design and Combat Performance. (N. F. Silsbee, Aviation, Vol. 4I, No. I I, Nov., 1942, pp. 96-99 and 307-320.)

Flight Performance Recorded Automatically in Ground Station. (Cut by Censor.) (Autom. Ind., Vol. 88 , No. I, $1 / 1 / 43$, p. 38 .)

Dead Reckoning Navigation. (E. L. Collins, Flying, Vol. 32, No. 5, May, I943, pp. 60-66 and 132.)

Equipment, including Controls.

$259 \quad 9807$ Canada

New Fluorescent Lamp Ballast for Lighting of Aircraft Instruments. (Canadian Aviation, Vol. 16, No. I, Jan., 1943, p. I00.)

$\begin{array}{lll}260 & 9879 & \text { U.S.A. } \\ 261 & 9882 & \text { U.S.A. } \\ 262 & 9970 & \text { U.S.A. } \\ 263 & 9975 & \text { U.S.A. } \\ 264 & 9980 & \text { U.S.A. } \\ 265 & 10002 & \text { U.S.A. } \\ 266 & 10015 & \text { U.S.A. }\end{array}$

$267 \quad 10089$ Germany

New Simplified Brake Valve. (Am. Av., Vol. 6, No. $16,15 / 1 / 43$, p. 47 .)

New Dust-Tight Relay for Aircraft. (Am. Av., Vol. 6, No. I6, 15/1/43, p. 47.)

Bevel Gears in Aircraft. (A. H. Candee, A.S.M.E., Preprint, Oct. Meeting, 1942.)

Portable .Steel Runways. (Am. Av., Vol. 6, No. 20, $15 / 3 / 43$, p. 24.)

Bird-Proof Windshields. (Am. Av., Vol. 6, No. 20, 15/3/43, p. 54.)

Windshield Protects Pilots from.Birds. (Autom. Ind., Vol. 88 , No. 4, $15 / 2 / 43$, p. 5o.)

Crash-Proof Fuel Tanks. (J. W. Baird, Preprint, National Aeron. Meeting of the S.A.E., March I 2-13, 1942.)

The Development of Electrical Equipment in Aircraft. (E. Ruhlemann, Luftwissen, Vol. Io, No. 3, March, 1943, pp. 83-85.)

268 IoI 46 G.B. ...

The Icing of Aircraft. (Aeronautics, Vol. 8, No. 2, March, 1943, pp. 60-61.)

$269 \operatorname{Ior} 5^{6}$ G.B. ...

New Automatic Aircraft Control System (Sperry Patent). (Aeronautics, Vol. 8, No. 2, March, I943, p. 5I.)

$270 \quad 10259$ U.S.A.

Electrical Protective Devices for Aircraft. (J. C. Lebens, Aero Digest, Vol. 42, No. 3, March, 1943, pp. 229-231.)

$271 \quad 10273$ U.S.A. New Windshield Glass, Safe Against Bird Crashes. (Aero Digest, Vol. 42, No. 3, March, 1943, pp. 404-405.) 
ITEM R.T.P

No. REF.

$272 \quad$ I0335 Canada

2739801 Canada

$2749824 \quad$ U.S.A.

$2759846 \quad$ U.S.A

$276 \quad 9979 \quad$ U.S.A.

277 10277 U.S.A.

$278 \quad$ Io329 Canada

$279 \quad 10336$ Canada

$280 \quad 10442$ G.B. ...

28 r 10489 G.B. ...

$282 \quad 9836 \quad$ U.S.A.

$283 \quad 9871 \quad$ U.S.A

2849873 U.S.A

2859976 U.S.A.

2869999 U.S.A.

$287 \quad 10057$ G.B. ...

$288 \quad 10085$ Germany

289 joo86 Germany

29010354 U.S.A.

$291 \quad 10378$ U.S.A.
TITLE AND JOURNAL.

Aircraft Fuel Tank Cap Assembly. (Canadian Av., Vol. I5, No. I 2, Dec., 1942, p. 144.)

Airfields and Maintenance.

.. New Airport Made on an Ontario Pasture (Photo). (Canadian Aviation, Vol. I6, No. I, Jan., 1943. p. 45.)

New Portable Hydraulic Aeroplane Lift. (Autom. Ind., Vol. 88, No. 2, 15/1/43, p. 45.)

Plywood Hangar (Photo). (Am. Av., Vol. 6, No.I I $1 /$ I I $_{4} / 2, \mathrm{p} .48$.)

Tyre Remover-New Device. (Am. Av., Vol. 6, No. 20, I $5 / 3 / 43$, p. 49 .)

Suitches for Airport Runway Lighting. (Aero Digest, Vol. 42, No. 3,-March, 1943, pp. 432-434.)

Maintenance of Plexiglas Sections on Aircraft. (Canadian Av., Vol. I5, No. 12, Dec., 1942, pp. II6-iI7 and i22.)

Extending Ladder for Servicing of Aircraft. (Canadian Av., Vol. I5, No. I 2, Dec., 1942, p. 148.)

Aerodrome Abstracts, Compiled by the Dept. of Scientific and Industrial Research, Abstracts Nos. 42-58. (Vol. 2, No. 3, 1943.)

Land Drainage Machinery $(I)$. (Engineer, Vol. I 75, No. $4,559,28 / 5 / 42$, pp. 420-421.)

Airscrews and Helicopters.

New Propeller having Two Single Blades Revolving in Opposite Directions for Horizontal Lifting. (G. W. Tidd, Am. Av., Vol. 6, No. I I, I/1 I/42, p. 16.)

Increased Production of Hollow Steel PropellerBlade. (Am. Av., Vol. 6, No. I7, r/2/43, p. 51.)

Hamilton Counter-Rotating Propeller. (Am. Av., Vol. 6, No. I7, I/2/43, p. 52.)

Sikorsky Helicopter. (Am. Av., Voi. 6, No. 20, 15/3/43, p. 24.)

V.D.M. Propeller Pitch Charging Mechanism. (Autom. Ind., Vol. 88, No. 4, 15/2/42, pp. 40-41.)

Improvements in Marine Propeller Bossing Design. (Mech. World, Vol. II3, No. 2,931, 5/3/43, p. 260.)

Methods for Balancing Airscrews. (H. Oschatz, Luftwissen, Vol. Io, No. 3, March, I943, pp. 69-72.)

The Coupling of Airscrew Blades in V.P. Mechanism. (W. Nitzsche, Luftwissen, Vol. Io, No. 3, March, 1943, pp. 74-77.)

Co-Axial Electric Propeller (Developed by CurtissWright). (Aviation, Vol. 41, No. 1 I, Nov., 1942, p. I53.)

Special Propeller for Trainer Planes. (Aviation, Vol. 4I, No. I I, Nov., 1942, p. 26r.) 
ITEM R.T.P.

No. REF.

TITLE AND JOURNAL.

$29^{2} \quad 10422$ U.S.A

Dual Rotation Propeller with Hydraulic Pitch Control (Six-Bladed) (Photograph). (Autom. Ind., Vol. 88, No. I, I/1/43, p. 45.)

293 I0558 U.S.A.

294 I0602 Canada New Counter Rotating Constant Speed Propeller. (U.S. Air Services, Vol. 28, No. 2, Feb., I943, p. 28.)

Two-Place Helicopter (XR-4) (Photo). (Flying, Vol. 32, No. 5, May, 1943, p. 71.)

\section{Engines and Accessories.}

Named Types.

29598 I8 G.B.

Rolls Royce Merlin 61. (M. W. Bourdon, Autom. Ind., Vol. 88, No. 2, I 5/1/43, pp. 34-35 and 7 o.)

$296 \quad 9827$ Japan

297 998I U.S.A.

Japanese Engine Removed from Aircraft After Crashing (Photo). (Am. Av., Vol. 6, No. I I, I $/$ I $1 / 42$, p. 4.)

Lycomiings New Flat Geared Engine (Six-Cylinder, Horizontally Opposed Model of 2 ro h.p. (Photograph). (Am. Av., Vol. 6, No. 20, I 5/3/43; p. $5^{8 .)}$

$298 \quad 10052$ G.B. ...

Diesel Marine Machinery, Harland and Wolff Engine. (Paper Presented to the Inst. of Mech. Engrs.). (C. C. Pounder, Mech. World, Vol. I I 3, No. 2,93i, 5/3/43, pp. 239-242.)

$\begin{array}{lrl}299 & 10087 & \text { Germany } \\ 300 & 10088 & \text { Germany } \\ 301 & 10098 & \text { G.B. ... } \\ 3 \dot{0} 2 & 1027 \text { I } & \text { U.S.A. }\end{array}$

Aircraft Diesel Engine. (Luftwissen, Vol. Io, No. 3, March, 1943, pp. 77-79.)

Historical Development of Siemens and B.M.W. Aircraft Engines. (H. Lohner, Luftwissen, Vol. Io, No. 3, March, 1943, pp. 80-82.)

Plastics in the Wright Cyclone Engine. (Plastics, Vol. 7, No. 72, May, 1943, p. 213.)

Lycomings New Six-Cylinder 2 1o h.p. Horizontally Opposed Engine. (Aero Digest, Vol. 42, No. 3, March, 1943, p. 374.)

303 I037 I Germany

Design Details of B.M.W. $80 \mathrm{r}$ A Engine. (M. V. Cave, Aviation, Vol. 4I, No. II, Nov., 1942, pp. 228-229 and 29I-299.)

30410399 U.S.A.

A New Development in Two-Stroke Diesels (Sulzer). (Antom. Ind., Vol. 88, No. 5, I/3/43, pp. $3^{\left.\mathrm{O}-3^{\mathrm{I}} \text { and } 47 .\right)}$

$305 \quad 10426$ U.S.A.

New Model Carburettor for Twin Wasp Engine. (Autom. Ind., Vol. 88, No. 1, 1/1/43, p. 76.)

$306 \quad 10563$ U.S.A.

Twin-Row I, 250 h.p. Pratt and Whitney "Wasps" (Photo). (U.S. Air Services, Vol. 28 , No. 2, Feb., 1943, p. I8.)

307 10566 Germany ... Development of the D.B. 601 Aero Engine. (Motor Schau., Vol. 7, No. 2, Feb., 1943, pp. 58-6o.)

$308{ }_{10572}$ Germany ... The Development of the Diesel Fingine. (Motor Schau., Vol. 7, No. 3, March, 1943, pp. 105-107.)

309 I0588 Canada ... The Allison Liquid-Cooled Engine. (W. Levenor, Flying, Vol. $3^{2}$, No. 5, May, 1943, pp. 28-3 I and 84-92.) 
ITEM
No.

3109780 U.S.A

3 II 9822 U.S.A.

$3^{12} 10019$ U.S.A.

$3^{13} 10020$ U.S.A.

$3^{14} \quad 10033$ U.S.A.

$315 \quad 10263$ U.S.A.

$316 \quad 10268$ U.S.A.

$317 \quad 10355$ U.S.A.

$318 \quad 10526 \quad$ G.B. . .

31910567 Germany

$320 \quad 9783 \quad$ U.S.A.

32 I 9845 U.S.A.

3229901 U.S.A.

3239909 Germany

32499 I I Germany

$325 \quad 9972$ U.S.A.

$326 \quad 10298$ Canada

327 10319 U.S.A.

328 10430 G.B. ...
TITLE AND JOURNAL.

Design and Installation.

Variable Thrust Line Engine (Photo). (Autom. Ind., Vol. 87, No. 5, 1/9/42, p. 5o.)

Interchangeable Power Plants for British Bombers. (M. W. Bourdon, Autom. Ind., Vol. 88, No. 2, I 5/1/43, pp. 42-43.)

Co-Designing Aircraft Power Plants. (H. Karcher, S.A.E. Preprint, Nat. Aeron. Meeting, April 8-9, 1943.)

General Aspects of Aircraft Power Plant Installation. (T. Hammen, S.A.E. Preprint, Nat. Aeron. Meeting, April 8-9, 1943.)

Harmonic Coefficients of Engine Torque Curves. (F. Porter, J. App. Mech., Vol. 1o, No. I, March, 1943, pp. 38-48.)

Diesel Auxiliary Power Unit for Large Aircraft, (E. M. Wilson, Aero Digest, Vol. 42, No. 3, March, 1943, pp: 244-251.)

An Evaluation of Engine Types. (E. M. Lester, Aero Digest, Vol. 42, No. 3, March, 1943, pp. $3^{64}, 374,417-424$.)

Wright Uses Plastic Engine Parts to Save Alnminium. (Aviation, Vol. 4I, No. I I, Nov., I942, p. 53.)

Hydraulically Operated Clutches. (R. WaringBrown, Mech. World, Vol. II3, No. 2,940, 7/5/43, pp. 489-49I and 499.)

Model Aircraft Petrol Engine. (A. Thusius, Motor Schau., Vol. 7, No. 2, Feb., I943, pp. 6I-64.)

Thting and Efficiency.

F'undamentals of Good Carburization. (Metal Progress, Vol. 42, No. 5, Nov., I942, pp. 849-855.)

Wright Co. Conducts Cold Weather Engine Tests. (Äm. Av., Vol. 6, No. I I, I/II/42, p. 48.)

Volumetric Efficiency for I.C. Lngines. (P. H. Schweitzer, Autom. Eng., Vòl. 33, No. "434, March, 1942, pp. 107-108.)

Measures for Ensuring the Reliability of Aircraft Engines. (H. Konba, Luftwissen, Vol. Io, No. 2, Feb., 1943, pp. 38-42.)

Measurement of Piston Temperature. Under Load. (W. Glaser, Luftwissen, Vol. so, No. 2, Feb., 1943, pp. 44-49.)

On the Definition of Volumetric Efficiency. (P. H. Schweitzer, A.S.M.E. Preprint, Nov. Meeting, I942.)

Engines and Altitudes. (R. Sydney, Flying, Vol. 32, No. 3, March, I943, pp. 30-32 and 8o-82.)

Sub-Zero Test Cell for Engine Tests. (Flying, Vol. 32, No. 3, March, 1943, p. 94.)

The Conditioning of Bearing Surfaces. (H. Higinbotham, Mech. World, Vol. I I3, No. 2,94I, I $4 / 5 / 43$, Pp. 535-537.) 
ITEM

No.

$329 \quad 9855$ G.B. . .

$33^{\circ} 10016$ U.S.A.

$33^{I}$ I 0017 U.S.A.

$33^{2}$ I00I8, U.S.A.

333

334

roo94 G.B. ...

33510097 G.B. ...

$336 \quad 10025$ U.S.A.

33710369 U.S.A.

$33^{8} 10400$ U.S.A.

$3391054^{\circ}$ G.B. ...

$340 \quad \mathrm{IO}_{3} 85$ G.B. ...

341 10450 G.B. ...

34210549 G.B. ...

$343 \quad 9823 \quad$ U.S.A.

3449849 G.B. ...

3459966 G.B. ...

$346 \quad 10045$ G.B. ...
TITLE AND JOURNAL.

Drives, Piston Rings, etc.

Electrical Indicator Drives-Methods of Synchronizing Cathode Ray Oscillograph Engine Indicators. (J. G. G. Hempson, Airc. Eng., Vol. I 7, No. 170, April, 1943, pp. 98-99.)

iston Rings and Oil Control in Two-Cycle. High Output Diesel Engines. (F. G. Shoemaker and R. Allbright, A.S.M.E. Preprint, Oil and Gas Power Conference, June 17-19, 1942.)

Solutions for Diesel Piston Problems. (F. Zollner, A.S.M.E. Preprint, Oil and Gas Power Conference.)

Intake Systems for Aircraft Engines. (C. T. Doman, S.A.E. Preprint, Nat. Aeron. Meeting, April 8-9, 1943.)

General Requirements of A.C. Motor Starters. (Mech. World, Vol. I13, No. 2,931, 5/3/43, pp. $25^{6-259 .)}$

New Plastic Cylinder for Servo Unit. (Plastics, Vol. 7, No. 72, May, 1943; pp. 194-I95.)

Ultra-Centrifuge with Plastic Rotor. (Plastics, Vol. 7, No. 72, May, 1942, pp. 212-213.)

Cooling Characteristics of Steel and Aluminium Finned Cylinders for In-Line Air-Cooled Engines. (M. Piry, S.A.E. Preprint, Nat. Aeron. Meeting, April 8-9, 1943.)

Piston Rings in Aircraft Engine Maintenance. (P. S. Lane, Aviation, Vol. 4I, No. I I, Nov., 1942, pp. 205-207 and 339.)

Electronic Variable Speed Drive. (S. D. Fendley, Autom. Ind., Val. 88, No. 5, 1/3/43, pp. 32-33 and $5 \mathrm{I}$.)

Carburettor Air Scoops. (F. C. Mock, Airc. Eng., Vol. I 5, No. I7 I, May, I943, pp. I 35-143.)

\section{Bearings.}

... Fixing Bearings. (Metal Industry, Vol. 62, No. 21 , $21 / 5 / 43$, p. 324.)

Ball and Roller Bearings (Collection of Abstracts on (1) Design and Applications, (2) Materials and Production, (3) Friction and Lubrication). (I.A.E. Reports, No. II, Nov., I942.)

Roller Bearings. ('Trade and Engineering Times, Vol. 52, No. 95, April, 1943, p. 30.)

Turbines, Pumps, Boilers.

Hamilton-Whitfield Blower. (Autom. Ind., Vol. 88 , No. $2,15 / 1.43$, pp. 44 and 82.$)$

The Internal Combustion Turbine. (C. C. Pounder, Vol. I I3, No. 2,936, 9/4/43, p. 379.)

Large Forced Circulation Boiler (Contd.). (Engineer, Vol. 175, No. 4,556, 7/5/43, pp. 377-378.)

The Boiler Water Treatment. (Mech. World, Vol. II3, No. 2,934, 26/3/42, p. 327.) 
ITEM R.T.P.

No. REF

347 10049 G.B. ..

$34^{8} 1005^{1}$ G.B. ...

34910513 G.B. ..

$35^{\circ} \quad 10527$ G.B.

$35^{\mathrm{I}} 10574$ U.S.A.

$35^{2} \quad 10582$ U.S.A.

3539902 G.B. .

354 I00I3. G.B. .

$\begin{array}{lll}355 & 10053 & \text { G.B. } \\ 35^{6} & 10289 & \text { G.B. }\end{array}$

357 I0435 G.B.

$35^{8} \quad 1043^{6}$ G.B. ...

359 ro594 Canada

$3^{60} \quad 9^{863}$ G.B. ...

36r 9907 G.B. ...

$362 \quad 997^{1}$ U.S.A.

$3^{63} \quad 9985$ G.B. ...
TITLE AND JOURNAL.

The Power Station Boiler House. (Mech. World, Vol. 1 I3, No. 2,934, 26/3/43, pp. 322-324.)

The Howden-Johnson Boiler. (Paper Presented to the Inst. of Mech. Engs.) (C. C. Pounder, Mech. World, Vol. I 13 , No. 2,934, 26/3/43, pp. 340-34I.)

Pump for High Temperature Liquids. (Engineer, Vol. I75, No. 4,558, $21 / 5 / 43$, p. 4I 4.)

Compressed Air Venturi Ejectors and Blowers. (P. J. Finn, Mech. World, Vol. I I3, No. 2,940, 7/5/43, pp. 494-496.)

Hydraulic Turbine Practice of the Tennessee Valley Authority. (H. J. Petersen and J. F. Roberts, Mech. Eng.,. Vol. 65, No. 4, April, I943, pp. 237-244.)

Gas Turbine Locomotive with Electrical Transmission. (P. R. Sidler, Mech. Eng., Vol. 65, No. 4, April, 1943, pp. 26i-266.)

\section{Fuels and Lubricants.}

Fuels-General.

Unifying Road Transport (Use of Indigenous Fuels). (C. Ridley, Autom. Eng., Vol. 33, No. 434, March, I942, pp. Iog-I I 4.)

Fuel Research Intelligence Section. (Issued by Fuel Research Station, E. Greenwich.) (Summary for two weeks ending I 3 and 20 March, I 943.)

Utilisation of Waste Fuels. (Mech. World, Vol. I I , No. 2,93 I, 5/3/43, p. 242.)

World Production of Petroleum and its Substitutes -Rough Estimates for i942. (The Petroleum Times, Vol. 47, No. 1, I94, I/5/43, p. 2 10.)

Fuel Research Intelligence Section Abstracts (1o and 17 April, I943.)

Fuel Research Intelligence Section Abstracts (24 April and I May, I943).

Airline Fuel Consumption. (M. G. Beard, Flying, Vol. $3^{2}$, No. 5, May, 1943, pp. $5^{6-5^{8}}$ and I 20-1 24.)

Gaseous Fuels.

Substitution of Acetylene by Propane or Coal Gas. (Airc. Eng., Vol. I5, No. 170, April, 1943, p. 122.)

Producer Gas for Motor Transport. (Autom. Eng., Vol. 33, No. 434, March, 1942, p. I 28.)

Research Programme of the Institute of Gas Technology. (H. Vogtborg, A.S.M.E. Preprint, Oct. Meeting, 1942.)

Producer Gas v. Petrol Operation in Germany. (Petroleum Times, Vol. 47, No. I, I93, I $7 / 4 / 43$, p. 190.) 

R.T.P

No.

$364 \quad 10095$ U.S.A.

$3^{65}$ 10407. G.B. ...

$3^{66} \quad 10429$ G.B. ...

$367 \quad 9874$ U.S.A.

368 I0006 U.S.A.

$369 \quad 10233$ U.S.A.

37

$370 \quad 10043$ G.B. ...

$37310585^{\prime \prime}$ U.S.A.

$3749899 \quad$ G.B. . .

3759905 G.B. ...

$376 \quad 10023$ U.S.A.

377 Ior34 G.B. ...

378 IоI35 G.B.

$379 \operatorname{Ior} 36 \quad$ G.B. . .

$3^{80} \quad$ IO137 G.B. . .
TITLE AND JOURNAL.

Improved Process for Making Neohexane. (Autom. Ind., Vol. 88, No. 4, $\mathrm{I}_{5} / 2 / 43$, p. $5^{8}$.)

Removal of Sulphur from Gaseous Fuels for Heating Ferrous Metals. (A. Preece, Engineering, Vol. I 55, No. 4,036, 2 I $/ 5 / 43$, pp. 405-406.) Practical Gas Carburising. (Mech. World, Vol. I I 3, No. 2,94I , 14/5/43, pp. 524-526.)

Catalytic Processes, etc.

Houdry Process for Super Aviation Fuel. (Am. Av., Vol. 6, No. I 7, 1/2/43, p. 54.)

New Catalytic Process for Super Aviation Fuel (Houdry Process). (Autom. Ind., Vol. 88, No. 4, I 5/2/43, pp. 58-59.)

Fluid Catalytic Cracking Plant (Photo). (Ind. Eng. and Chem. (News Ed.); Vol. 2I, No. 5, March Iө, r943, p. 307.)

Coal, Lignite.

The Storage of Coal for Industrial Purposes. (Paper issued by the Ministry of Fuel.) (R. A. A. Taylor, Mech. World, Vol. I13, No. 2,934, 26/3/43, pp. 317-320.)

Coal Utilisation Research. (Engineer, Vol. 175, No. 4,557 , I $4 / 5 / 43$, pp. $3^{86-389 .)}$

Lignite-Influence. of Storage Conditions upon Size Degradation, Size Stability, and Friability. (C. J. Eckhardt, A.S.M.E. Preprint, April 26 and 28, 1943.)

Mixtures of Oil and Coal in Boiler Furnaces (Shortage of Fuel Oil). (J. Blizard, Mech. Eng., Vol. 65 , No. 4, April, I943, pp. 278-284.)

Oils and Lubricants.

Oil Engine Indicator (Based on Pre-Exhaust Gas Pressure). (Autom. Eng., Vol. 33, No. 434, March, 1942, p. 103.)

Ou Coolers. (E. Steintz and F. J. Grose, Autom. Eng., Vol. 33, No. 434, March, I943, pp. I 2 I-1 22.)

Aircraft Oil Systems-High' Altitude Problems.

(H. E. Moerman, S.A.E. Preprint, Nat. Aeron. Meeting, April 8-9, 1943.)

Insulating Oil for Cables. (S. Beckinsale, J. Inst. Elect. Engs., Vol. 9, No: I3, Feb., 1943, p. 3.) Mineral Oils for Transformers and Switchgear. (A. A. Pollit, J. Inst. Elect. Engs., Vol. 9, No. I3, Feb., 1943, pp. I 5-22.)

Insulating Oil in Relation to Circuit-Breaker Failures. (W. Fordham Cooper, J. Inst. Elect. Engs., Vol. 9, No. r3, Feb., I943, pp. 23-28.)

Maintenance of Insulating Oils in the Field. (L. H. Welch, J. Inst. Elect. Engs., Vol. 9, No. I 3, Feb., I943, pp. 29-34.) 


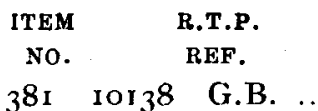

382 IоI39 G.B. ..

$383 \quad 10234 \quad$ France

$384 \quad 10285 \quad$ U.S.A.

385 Io288 Germany

$386 \quad 10397$ U.S.A.

387 10452 G.B. . .

TITLE AND JOURNAL.

The Manufacture and Testing of Oils and Oil-Resin Saturants for Use in Electrical Equipment. (A. W. Thompson and J. C. 'Wood-Mallock, Vol. 9, No. 13, Feb., 1942, pp. 35-53.)

Discussion on Symposium of Papers on "Insulating Oils." (J. Inst. Elect. Engs., Vol. 9, No. 13, Feb., I943, pp. 53-64.)

Oil Discovery at Saint Gaudens. (Ind. Eng. and Chem. (News Ed.), Vol. 21, No. 5, March ıo, I943, p. 3I9.)

Oxidation-Corrosion of Lubricating Oils. (C. I. Pope and D. A. Hall, A.S.T.M. Bulletin, No. I 2 I, March, 1943, pp. 29-32.)

Recent Views on the German Oil Position. (The Petroleum Times, Vol. 47, No. I, 194, 1/5/43, pp. 203-204.)

Refining of Used Crankcase Oil. (Autom. Ind., Vol. 88, No. $5,1 / 3 / 43$, pp. 24 and 48 .)

The Measurement of Aeration (Oils). (H. R. Mills and W. Michalski, I.A.E. Reports, No. I,943I,947, 24/3/43, pp. 3-20.)

\section{Theory of Elasticity}

(Stresses, Fatigue Strength, Vibration Resistance of Materials).

388

99J 2 Germany

389 9969 U.S.A.

$390 \quad 9997$ U.S.A.

$3911002 \mathrm{I}$ U.S.A.

39210024 U.S.A.

393 Ioo3o U.S.A.

394 roo32 U.S.A.

395 10202 Germany

$396 \quad 10205$ Germany

397 Io206 Germany
Stress Increases in Hollow Thin-Walled Section Under Torsion. (A. Weigand, Luftwissen, Vol. Io, No. 2, Feb., I943, pp. 49-5o.)

Behaviour of Plywood Under Repeated Stresses. (A. G. H. Dietz and H. Grinsfelder, A.S.M.E. Preprint, Oct. Meeting, I942.)

Fatigue of Metals as Influenced by Design and Internal Stresses. (J. O. Almen, Autom. Ind., Vol. 88, No. 4, I5/2/43, pp. 28-3I and 88.)

Improving the Fatigue Strength of Engine Parts. (J. O. Almen, S.A.E. "Preprint, Nat. Aeron. Meeting, April 8-9, I943.)

Effect of Openings in Moulded Plywood Structures. (E. J. Marhoefer, S.A.E. Preprint, Nat. Aeron. Meeting, April 8-9, I943.)

The Distribution of Strains in the Rolling Process, (C. W. Macgreggor, J. App. Mech., Vol. ro, No. I, March, 1943, pp. '13-20.)

Oscillations of Suspension Bridges. (H. Reissner, J. App. Mech., Vol. Io, No. I, March, 1943, pp. 23-32.)

Natural Frequencies of Torsional Systems, including Elastically Mounted Epicyclic Gearing. (W. Benz, L.F.F., Vol. 2o, No. 2, 27/2/43, pp. 46-47.) The Drawing of Tough Materials Through Convergent Conical Dies. (T. Poschl, Ing. Archiv., Vol. 13, No. 6, 1943, pp. 342-354.)

The Bending Deflection of a Circular Plate Under Eccentric Loads. (W. Muller, Ing. Archiv., Vol. 13, No. 6, 1943, pp. 355-376.) 
ITEM R.T.P.

$398 \quad 10207$ Germany

399 rozo8 Germany

40310284 U.S.A.

40410480 U.S.A.

405 ro490 G.B. ...

407 I054I G.B. ...
406 I0501 U.S.A.

TITLE AND JOURNAL.

The Evaluation of Two Definite Integrals Required in Elastic Plate Theory. (H. R. Weber, Ing. Archiv., Vol. 13, No. 6, 1943, pp. 377-380.)

Theory of the Closed Circular Spring. (R. Sonntag, Ing. Archiv., Vol. 13, No. 6, 1943, pp. 380-397.) Computation of "Dynamic Modulus." (S. Walker, A.S.'T.M. Bulletin, No. I21, March, 1943, pp. 23-24.)

The Strength of Cylindrical Dies. (G. Sachs and J. D. Lubahn, A.S.M.E. Preprint, Paper to be

presented at June Meeting, 16 and i 8 June, 1943.)
Welding Contraction and Locked-up Stres8es. (Engineer, Vol. I75, No. 4,559, 28/5/43, pp. 423-425.)

Accelerated Creep Research Using Wire Specimen. (Sci. Am., Vol. I68, No. 3, March, I943, p. I 26.)

The Vibration Resistance of Engineering Materials. (W. L. Hatfield and others, Airc. Eng., Vol. 15, No. I7 I, May, I943, p. 144.)

\section{Materials.}

A. Properties.

General Properties of Some Materials.

409 I0034 U.S.A. $\quad \ldots$ Plastic Flow as an Unstable Process (Discussion). (L. H. Donnell, J. App. Mechs., Vol. Io, No. I, March, I943, pp. 49-5I.)

$410 \quad 10092$ G.B. .. Substitute Materials in War and Peace. (Published by the Royal. Inst. of Internat. Affairs.) (C. H. Desch, Plastics, Vol. 7, No. 72, May, 1943, pp. I 88-208.)

4 II IOIII G.B. ...
4 II IOI7O G.B. ...

The Corrosion and Fouling of Ships (Contd.). (C. Bengough and V. Shepheard, Engineering, Vol. I 55 , No. $4,034,7 / 5 / 43$, pp. $363-364$ and $378-380$.)

Industrial Metal Finishing. I. Aspects of the Corrosion of Metals and Alloys. (H. Silman, Sheet Metal Industry, Vol. I7, No. I93, May, I943, p. 836.)

4I3 roI 89 U.S.A.

Pigment Dispersion with Surface-Active Agents. (E. K. Fisher and C. W. Jerome, Ind. and Eng. Chem., Vol. 35, No. 3, March, I943, pp. 336-343.)

4 I4 Io19o U.S.A.

Preventing Internal Corrosion of Pipe Lines. (A. Wachter and S. S. Smith, Ind. and Eng. Chem., Vol. 35, No. 3, March, I943, p. 358.)

$4 I_{5}$ IoI97 G.B. ...

Inverse Segregation-A Study of Alloys of Wide Solidification Range. (M. L. Samuels and others, Metal Industry, Vol. 62, No. 20, 14/5/42, pp. 3II-3I3.)

416 Io24I G.B. ... ... The Corrosion and Fouling of Ships (Contd.). (Engineering, Vol. I 55. No. 4,035, 14/5/43, p. 394.)

417 I0388 G.B. ... ... Inverse Wegregation (Contd.). (M. L. Samuels and others, Metal Industry, Vol. 62, No. 21, $21 / 5 / 42$, pp. $3^{28-330 .)}$ 
ITEM R.T.P.

No. REF.

418 IO39I Germany

$419 \operatorname{lo} 409$ G.B. ...

$420 \quad 10488$ G.B. ...

$42 \mathrm{I} \quad 10515 \quad \mathrm{G} . \mathrm{B} . \ldots$

42210520 G.B. ...

423 ro528 G.B. $\ldots$

424. I0542 G.B. ...

$\begin{array}{lll}425 & 9786 & \text { U.S.A. } \\ 426 & 9789 & \text { U.S.A. }\end{array}$

$427 \quad 979^{2}$ U.S.A

$429 \quad 985^{2} \quad$ G.B. ...

$430 \quad 10046$ G.B. ...

43 I I 0048 G.B. ...

432 IOI 40 G.B. ...

43310240 G.B. ...

434 ro481 G.B. ...

435 ro482 G.B. ...

$43^{6}$ 10弓०6 G.B. ...
4289794 U.S.A.

TITLE AND JOURNAL.

The Behaviour of Certain Structural Materials in the Tropics. (A.T.Z., Vol. 44, NVo. I2, 25/6/4I, pp. 316-3I7.) (R.T.P. Translation.)

The Corrosion and Fouling of Ships. (G. D. Bengough and V. G. Shepheard, Vol. I 55, No. 4,036, pp. $416-417$.

Plasticity of Cold Metals. (Metal Industry, Vol. 62 , No. $22,28 / 5 / 43$, p. 348.)

Marine Corrosion. (Engineer, Vol.' 175 , No. 4,558, $2 \mathrm{I} / 5 / 43 ;$ pp. 4I5-4I6.)

Frictional. Properties of Metallic Films.r (1. I'. Hughes, Nature, Vol. I $5^{1}$, No. $3,836,8 / 5 / 43$, pp. 533-534.)

Crystal Structure and Wear-Resisting Properties of . Metals. (Mech. World, Vol. I I3, No. 2,940, $7 / 5 / 43$, pp. 498-499.)

Combined Rau Materials Board (First An. Report). (Airc. Eng., Vol. I5, No. I7 I, May, 1943, pp. I 43-148.)

Iron and Steel.

Brittleness in High Chromium Irons. (Metal Progress, Vol. 42, No. 5, Nov., 1942, pp. 860-966.)

Separation of High Speed Steels bys Spark Testing. (Metal Progress, Vol. 42, No. 5, Nov., I942, p. 868.)

Weldability of Steels. (Metal Progress, Vol. 42, No. 5, Nov., 1942, pp. 885-886.)

Machinability of Steels. (Metal Progress, Vol. 42, No. 5, Nov., I942, pp. 888-889 and 922.)

Properties of High Duty Cast Irons. (C. S. Darling, Mech. World, Vol. I I 3, No. 2,936, 9/4/43, pp. 393-396.)

Molybdenum Ore Dressing (Flow Sheet No. I I). (Mech. World, Vol. I I 3, No. 2.934, 26/3/42, pp. 329-330.)

Applications of the New Cast Irons. (C. S. Darling, Vol. I I 3, No. 2,934, 26/3/43, pp. 334-337.)

Some Electrical Supply Aspects of Ferro-Alloy Manufacture. (H. A. Sieveking, J. Inst. Elect. Engs., Vol. 9, No. 13, Feb., I943, pp. 65-72.;

The Microstructure of Lead-Bearing Steels. (Engineering, Vol. I 55, No. 4,035, p. 388 .)

References, Excluding Patents, to Iron-Vanadium and Iron-Titanium Alloys, I929-1942. (Science Library, Bibliographical Series, No. 586, 27/2/43.) Effect of Iron on Brass. (Science Library, Bibliographical Series, No. 588, 10/3/43.)

The Iron and Steel Institute-Annual Meeting and Proceedings. (Engineer, Vol. I75, No. 4,558, 2 I $/ 5 / 43$, pp. 404-405:)

Al. and $M \dot{g}$. Alloys.

4379825 U.S.A. $\quad \ldots$ Flux for Gas Welding of Magnesium Alloys. (Autom. Ind., Vol. 88, No. 2, 15/1/43, p. 46.) 


\begin{tabular}{|c|c|c|}
\hline $\begin{array}{r}\text { ITEM } \\
\text { No. }\end{array}$ & \multicolumn{2}{|c|}{$\begin{array}{c}\text { R.T.P. } \\
\text { REF. }\end{array}$} \\
\hline $43^{8}$ & 9959 & G.B. $\ldots$ \\
\hline+39 & IOOOI & U.S.A. \\
\hline 440 & 10054 & G.B. ... \\
\hline & & . \\
\hline 441 & 10057 & G.B. ... \\
\hline $44^{2}$ & 10100 & G.B. ... \\
\hline 443 & IOI 26 & G.B. $\ldots$ \\
\hline 444 & 10195 & G.B. $\ldots$ \\
\hline 445 & 10200 & Germany \\
\hline 446 & 10287 & U.S.A. \\
\hline 447 & 10389 & G.B. ... \\
\hline 448 & 10485 & G.B. $\ldots$ \\
\hline 449 & 9784 & U.S.A. \\
\hline $45^{\circ}$ & $979 \mathrm{I}$ & U.S.A. \\
\hline $45^{I}$ & 9795 & U.S.A. \\
\hline $45^{2}$ & 9796 & U.S.A. \\
\hline 453 & $985^{\circ}$ & G.B. $\ldots$ \\
\hline 454 & 9933 & U.S.A. \\
\hline 455 & 9961 & G.B. $\ldots$ \\
\hline $45^{6}$ & 10531 & Germany \\
\hline 457 & 10546 & G.B. . \\
\hline
\end{tabular}

TITLE AND JOURNAL.

Aluminium-Post War. (Metal Industry, Vol. 62, No. 19, 7/5/43, p. 294.)

New Manganese Alloy. (Autom. Ind., Vol. 88, No. $\therefore 4,15 / 2 / 43$, p. 46 .)

Magnesium-Present-Day Processes of Extraction.

(C. H. Desch, Mech. World, Vol. II3, No. 2,931, $5 / 3 / 43$, pp. 243-246.)

Melting Aluminium Borings and.Turnings. (Mech. World, Vol. I I3, No. 2,93 I, 5/3/43, p. 255.)

Joining Light Alloys with Adhesives (Redux Process). (Plastics, Vol. 7, No. 72, May, 1943, pp. 2 I 6-2 I 8.)

Drilling Deep Holes in Magnesium Alloys. (W. W. Gilbert and A. M. Lennie, Machinery, Vol. 62, No. I, $593,22 / 4 / 43$, pp. $437-440$.)

Forging Aluminium Alloys. (Metal Industry, Vol. 62 , No. $20,14 / 5 / 43$, p. 308 .)

Possibility of Reducing the Electrical Contact Resistance of Al. and Al. Alloys. (C. Wagner and V. Stern, L.F.F., Vol. 20 , No. ${ }^{2}, 27 / 2 / 43$, pp. 33-41.)

Annotated Bibliography of Aluminium Cleaning. (J. Harris and R. B. Mears, A.S.T.M. Bulletin, No. I 2 I, March, I943, pp. 33-38.)

Drilling Magnesium Alloys. (W. W. Gilbert and A. M. Lennie, Metal Industry, Vol. 62, No. 21, $2 \mathrm{I} / 5 / 43$, pp. $33^{\mathrm{I}-33^{2}}$.)

Induction Furnaces for Melting Al. Alloys. (M. Tama, Metal Industry, Vol. 62, No. 22, 28/5/43, pp. 34 I-342.)

\section{Non-Ferrous Metals.}

Supply and Demand for Copper. (Metal Progiess, Vol. 42, No. 5, Nov., I942, pp. 874-876.)

Oxidation of Copper. (Metal Progress, Vol. 42, No. 5, Nov., r942, pp. 962-964.)

New Alloying Method for Copper-Lead and Alumintum-Liead Alloys. (F. N. Rhines, Metal Progress, Vol. 42, No. 5, Nov., 1942, p. 89o.)

Copper Alloys. (Metal Progress, Vol. 42, No. 5, Nov., 1942, p. 89o.)

The Production of Double Curvature Aircraft Components-The Use of Zinc and Lead Alloy Punch and Die Sets. (A. J. T. Eyles, Mech. World, Vol. I I 3 , No. $2,936,9 / 4 / 43$, pp. $3^{80-382 .)}$

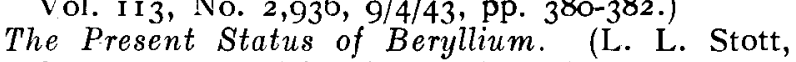
Paper Presented by the S.A.W.F..)

Precipitation in the Copper-Silver Alloys-II. (Metal Industry, Vol. 62, No. I9, $7 / 5 / 43$, p. 296.) Explosive Properties of Copper Azide $\mathrm{Cu}\left(\mathrm{N}_{3}\right)_{2}$. (A. Cirulis, Z.G.S.S., Vol. 38, No. 3, March, 1943, pp. 42-45.)

Allied Nickel Supply Position. (Trade and Engineering Times, Vol. 52, No. 95, April, 1943, p. I2.) 
ITEM R.T.P

No. REF.

$\begin{array}{crc}458 & 9977 & \text { U.S.A. } \\ 459 & 10038 & \text { U.S.A. } \\ 460 & 10041 & \text { U.S.A. } \\ & & \\ 461 & 10042 & \text { U.S.A. } \\ 462 & 10093 & \text { G.B. .. } \\ 463 & 10095 & \text { Germany }\end{array}$

46410096 Germany

465 Ioro4 Germany

466. Iог 87 U.S.A.

467 rorgi U.S.A.

468 IoI92 U.S.A.

$469 \quad 10207$ Germany

47010210 G.B. .

47 I IO2II G.B. ...

472 IO2I2 G.B. ...

47310215 G.B. ...

474 ro23I U.S.A.

$475 \quad 10337$ Canada

476 1044I G.B. ...

47710499 U.S.A.
TITLE AND JOURNAL.

Plastics.

New Plastics for Aircraft Parts. (Am. Av., Vol. 6, No. 2o, $15 / 3 / 43$, p. 27.)

Laminated Phenolic Bearings (Ryertex). (K. T. MacGill, Modern Plastics, Vol. 2o, No. 3, Nov., I942, pp. 76 and I I 2-I I 4.)

Behaviour of Plastics Under Vibrations. (B. J. Layan, Modern Plastics, Vol. 20, No. 3, Nov., 1942, pp. 83-88 and I 36-I 44.)

Plasticizers. (J. M: De Bell, Vol. 20, No. 3, Nov., 1942, pp. 89 and 128 .)

Polyvinyl-Acetate Adhesives. (E. E. Halls, Plastics, Vol. 7, No. 72, May, 1943, pp. I89-193.)

Plastic Bearings for Rolling Mills (from Kunstoffe). (Plastics, Vol. 7, No. 72, May; 1943, pp. 196-200.)

The Scope of Plastics in Automobile Engineering. (D. Warburton Brown, Plastics, Vol. 7 , No. $7^{2}$, May, 1943, pp. 2or-208.)

Design and Lubrication of Plastic Bearings. (Fordestechn., Vol. 32, pp. 26I-385.) (Plastics, Vol. 7 , No. 72 , May, I943, p. 209.)

Destructive Distillation of Lignocellulose. (R. Katzen and others, Ind. and Eng. Chem., Vol. 35, No. 3, March, 1943, pp. 302-305.)

Colouring Material for Copolymer Vinyl Chloride. Acetate Compounds. (F. G. Clark, Vol. 35, No. 3, March, I943, pp. 368-374.)

Creep and Creep Recovery in Plasticized Polyvinyl Chloride. (H. Leaderman, Ind. and Eng. Chem., Vol. 35, No. 3, March, I943, p. 374.)

Resinoid Bearings of the World's Largest Rolling Mill (from Kunstoffe, Aug., I942). · (J. Arens, British Plastics, Vol. I4, No. I68, May, I943, pp. 708-7 I 6.)

Fluorescent Plastics for Night Flying. (British Plastics, Vol. 14, No. 168, May, 1943, p. 7 I8.)

Use of Melamine Compounds in War. (British Plastics, Vol. I 4, No. I68, May, I943, p. 722.)

Education in the World of Plastics (Contd.). (V. E. Yarsley, British Plastics, Vol. I4, No. 168, May, 1943, pp. 728-737.)

Charts on Plastics. (British Plastics, Vol. I4, No. 168, May, I943, pp. 738-758.)

New Adhesive Plastic Saves Crude Rubber. (Ind. Eng. and Chem. (News Ed.), Vol. 2I, No. 5, $10 / 3 / 43$, p. $\left.3^{\mathrm{I}} 7_{\dot{i}}\right)$

New Insulation Materials (Varnished Nylon, etc.). (Canadian Av., Vol. I5, No. I2, Dec., r942, p: I 50.)

Plastic Abstracts issued by Controller of Chemical Research. (No: 43, March, I943.)

C.R. 39 Transparent Plastic of High Abrasion Resistance. (Sci. Am., Vol: 168, No. 3, March, 1943, p. I 24.) 
ITEM R.T.P.

NO. REF.

478 I0555 G.B. .

TITLE AND JOURNAL.

$4791057^{6}$ U.S.A.

Plastics-Uses for Surgery. (Trade and Engineering Times, Vol. 52, No. 95, April, 1943, p. 44.) Advances in Plastics During 1942. (G. M. Kline, Mech. Eng., Vol. 65, No. 4, April, 1943, pp. 245-247 and 260.)

Rubber (Nat. and Syn.).

$480 \quad 9984$ G.B. ...

Synthetic Rubber from Petroleum in Roumania. (E. A. Bell, Petroleum Times, Vol. 47, No. I, I $93,17 / 4 / 43$, p. I 84 .)

$48 \mathrm{I}$ I0040 U.S.A.

Fabrication of Polystrene.

No. 3, Nov., 1942, pp. 79 and I 22.)

48210068 U.S.A.

483 IoIO7 Germany

Rubber Replacements.

(E. G. Kimmich, Mech. Eng., Vol. 65, No. 2, Feb., 1943, pp. II3-I14.)

Coverings for Marine Cables. (Gummi-Zeitung, Vol. 54, p. 254.) (Plastics, Vol. 7, No. 72, May, 1943, p. 210.)

484 Ioro8 Germany

Rubber Derivatives Considered as Plastics. (Kunstoffe, Vol. II, p. I89.) (Plastics, Vol. 7, No. 72, May, 1943, p. 211.)

485 Iori4 U.S.A.

Determination of Total Sulphur in Rubber and Rubberlike Materials. (La Verne E. Cheyney, Ind. and Eng. Chem (Anal. Ed.), Vol. I5, No. 3, I 5/3/43, pp. I64-165.)

486 I0I88 U.S.A.

Electrical Properties of Neoprene. (F. L.. Yerzley, Ind. and Eng. Chem., Vol. 35, No. 3, March, I943, pp. 330-335.)

487 10230 U.S.A.

"Kem Pol" Synthetic Rubber from Domestic Vegetable Oils. (Ind. Eng. and Chem. (News Ed.), Vol. 21, No. 5, March II, 1943, pp. 306-307.)

$\begin{array}{ccc}488 & \text { ro416 } & \text { G.B. . } \\ 489 & \text { 10577. } & \text { U.S.A. }\end{array}$

Rheology of Rubber. (Nature, Vol. ${ }^{5}{ }^{1}$, No. 3,837 , 15/5/43, pp. 563-564.)

Advances in Rubber During 1942. (J. H. Dillon, Mech. Eng., Vol. 65, No. 4, April, 1943, pp. 248-25o.)

Glass, Concrete.

$49^{\circ} 9839$ U.S.A. $\quad$.. Fiberglass Fabric is Inner Braid of New Ignition Cable. (Am. Av., Vol. 6, No. I I, I/I I/42, p. 39.)

49 I 9903 U.S.A. … Glass Gauges. (Autom. Eng., Vol. 33, No. 434, March, I942,'p. I I 4.)

492 IOI3I G.B. ...

The Art of Glass Polishing (Book Review). (Nature, Vol. I 5 I, No.r——, 24/4/43, p. 459.)

493 I02I4 G.B. ...

Glass Plastics as Aircraft Structural Material. (British Plastics, Vol. I4, No. I68, May, 1943, p. 737.)

494 i 10232 U.S.A.

Pyrex Glass Developments. (Ind. and Eng. Chem. (News Ed.), Vol. 21, No. 5, March Io, 1943, pp. 31 2-313.)

495 I0286 U.S.A.

Discussion of Paper on Effect of Size of Specimens in Studies of Durability of Concrete as Affected by Aggregates: (A.S.T.M. Bulletin, No. I2I, March, I943, pp. 29-32.) 


$\begin{array}{ccc}\text { ITEM } & \text { R.T.P. } \\ \text { No. } & \text { REF. } \\ 496 & 10530 & \text { G.B. } \quad \ldots \\ & & \\ 497 & 10584 & \text { U.S.A. }\end{array}$

$4989992 \quad$ U.S.A.

499 I0099 G.B. ...

$500 \quad 10002$ G.B. ...

5or 10105 Germany

502 Ioro6 Germany

50310213 G.B. ...

$504 \quad 10225$ G.B. ...

50510349 U.S.A:

$506 \quad 10529$ G.B. ...

$5 \% 79870 \quad$ U.S.A.

508 10009 U.S.A.

50910029 U.S.A.

$510 \quad 10066$ U.S.A.

5 II 1007 I U.S.A.

512 10072 U.S.A.
TITLE AND JOURNAL.

Fibrous Glass Electrical Insulation. (A. M. Robertson, Mech. World, Vol. II3, No. 2,940, 7/5/43, pp. 507-509.)

Glass for Precision Gauges. (H. B. Hambleton, Mech. Eng., Vol. 65. No. 4, April, 1943, pp. 274-276.)

Resins, Paper.

Discussion of the Properties of Casein Glues as Related to the Fabrication of Aircraft. ( $\mathrm{H}$. Oldham, Commercial Aviation, Vol. 4, No. I 2, Dec., 1942, pp. 98-100.)

Aircraft Parts of Resin-Impregnated Paper. (H. W. Perry, Plastics; Vol. 7, No. 72, May, I943, p. 2I 4.)

Resinoids and Other Plastics as Film Formers. (XVII-Peculiarities of Physical Properties of High Polymers.) (B. J. Biajnikoff, Plastics, Vol. 7, No. 72, May, 1943, pp. 222-230.)

Impregnation of Textile Fabrics with Acrylic Resins. (Chemiker Ztg., Vol. 66, No. 3, p. 24, 1942.) (Plastics, Vol. 7, No. 72, May, I943, p. 2 10.)

Electrical Strength of Commercial Resin-Impregnated Papers and F'abric Laminates. (Kunstoffe Techn., Vol. I I, p. 252.) (Plastics, Vol. 7, No. 72, May, I943, p. 210.)

Leather Fibres Treated with Synthetic Resins. (British Plastics, Vol. 14, No. 168, May, 1943, p. 437.)

The Redux Process (Synthetic Resin Adhesive). (Engineer, Vol. I75, No. 4,557, I 4/5/43, p. 395.)

Fabricating Plant Parts from Paper. (Aviation, Vol. 4I, No. I I, Nov., 1942, p. I 38.)

Papiermache Aircraft Components (Pytram). (Mech. World, Vol. II3, No. 2,940; 7/5/43, p. 503.)

Plywood, Wood.

U.S. Research in Aircraft Plywood. (Am. Av., Vol. 6, No. I7, 1/2/43, p. 5o.)

The Use of Wood for Aircraft. (Autom. Ind., Vol. 88, No: $4,15 / 2 / 43$, p. 27.)

Delamination Tests of Plywood and a-Proposed Specification. (C. W. Muhlenbruch, A.S.M.E. Preprints, April 26-28, 1943.)

Problems in the Use of Plywood in Aeroplane Construction. (A. Klemin, Mech. Eng., Vol. 65, No. 2, Feb., 1943, pp. I05-109.)

Plywood in Aircraft Construction. (G. A. Allwood, Mech. Eng., Vol. 65, No. I, Jan., 1943, pp. I4-I6.)

Making Plywood with Multi-Directional Pressure. (J. S. Barnes, Mech. Eng., Vol. 65, No. I, Jan., I943, pp. 17-20.) 


\begin{tabular}{|c|c|c|}
\hline \multirow{2}{*}{$\begin{array}{c}\text { ITEM } \\
\text { No. } \\
5^{1} 3\end{array}$} & \multicolumn{2}{|c|}{$\begin{array}{l}\text { R.T.P. } \\
\text { REF. }\end{array}$} \\
\hline & 10127 & G.B. ... \\
\hline & & \\
\hline 514 & IOI 86 & U.S.A. \\
\hline $5^{15}$ & 10264 & U.S.A. \\
\hline 516 & 10299 & Canada \\
\hline $5^{17}$ & 10510 & G.B. ... \\
\hline $5^{18}$ & $10_{5}^{11}$ & U.S.A. \\
\hline
\end{tabular}

... Determination of the Water Content of Wood and Other Substances by Means of Ternary Azeo. tropic Mixtures. (Nature, Vol. 151, No. 3,833,

Partial Pyrolysis of Wood. (R. W. Merritt and A. A. White, Ind. and Eng. Chem., Vol. 35, No.' 3, March, 1943, pp. 297-301.)

Douglas Fir Plywood for Aircraft. (N. S. Perkins, Aero Digest, Vol. 42, No. 3, March, 1943; pp.

260 and $384-386$.
Setting Glue by High Frequency Currents (for Wooden Spars). (G. R. Reiss, Flying, Vol. 32, No. 3, March, 1943, pp. 33-34 and 147.)

Wood and Steel. (Engineer, Vol. 175, No. 4,558, $2 \mathrm{I} / 5 / 43$, pp. 4 10-4I I.)

Wood in Aircraft Construction (from the A.S.M.E., Dec., I942). (R. J. Nebesar, Engineer, Vol. 175, No. 4,558, 2 1/5/43, pp. 41 2-413.)

Temp. Indicating Lacquers and Crayons.

5 I9 9864 G.B. ... $\quad$... Temperature Indicating Crayons. (Airc. Eng., Vol.

$520 \quad 10504$ U.S.A.

I 5, No. 7o, April, I943, p. I 22.)

Temperature Recording Lacquer (Sharp Melting Point). (Sci. Am., Vol. 168, No. 3, March, 1943, p. I32.)

B. Fabrication.

Heat Treatment.

$5^{21} \quad 9787$ U.S.A. $\quad \ldots$ Automatic Units for Heat Treating High Explosive Shells. (Metal Progress, Vol. 42, No. 5, Nov., I942, pp. 86 I-866.)

522. $9797^{\circ}$ U.S.A. $\quad$.. Proper Heat Treatment of Tool Steels. (Metal Progress, Vol. 42, No. 5; Nov., I942, pp. 896-898.)

52310069 U.S.A. ... Analyzing Heat Flow in Cyclic Furnace Operation. (C. B. Bradley and C. E. Ernst, Mech. Eng., Vol. 65, No. 2, Feb., 1943, pp. I 25-1 29.)

524 IoI 8 G.B. ... ".. Hard Surfacing of Metals. (Mech. World, Vol. II 3 , No. $2,938,23 / 4 / 43$, pp. $437-43^{8}$.)

52510486 G.B. ...

... Combustion Safeguards in Gas-Fired Furnaces. (T. A. Cohen, Metal Industry, Vol. 62, No. 22, 28/5/43, pp. 343-344.)

526 I0494 G.B. ...

Development of the Hot Spraying of Poudered Materials. (W. E. Ballard, Chemistry and Industry, Vol. 62, No. 21, May 22, 1943, pp. I90-194.)

527 10496 U.S.A. ... Induction Heating Applied to Steel Propeller Shanks. (Sci. Am., Vol. I68, No. 3, March, I943, p. Io8.)

52810498 U.S.A. $\quad \ldots$ Induction Hardening Applied to Engine Crant. shafts. (Sci. Am., Vol. 168, No. 3, March, I943, pp. I 23-1 24.)

Plating and Protective Coatings.

5299790 U.S.A. $\quad$... Surface Preparation for Spot Welding Aluminium. (Metal Progress, Vol. 42, No. 5, Nov., 1942, pp. 9I 2-9 3 and 929.) 
TITLES AND REFERENCES O’ं ARTICLES AND PAPERS.

\begin{tabular}{|c|c|c|}
\hline \multirow{2}{*}{$\begin{array}{c}\text { ITEM } \\
\text { NO. } \\
53^{\circ}\end{array}$} & \multicolumn{2}{|c|}{$\begin{array}{l}\text { R.T.P. } \\
\text { REF. }\end{array}$} \\
\hline & 10103 & Germany \\
\hline $53^{1}$ & 10159 & G.B. $\ldots$ \\
\hline $53^{2}$ & 10199 & G.B. $\ldots$ \\
\hline 33 & 10237 & G.B. $\ldots$ \\
\hline
\end{tabular}

TITLE AND JOURNAL.

... Frotection of Zine (from Techn. Zbl. Prakt. Mettalbearbeitung, Vol. 5., . 583). (Plastics, Vol. 7 , No. 72, May, 1943, p. 209.)

Deoxidation with Beryllium. (Sheet Metal Industry, Vol. I7, No. I93, May, I943, p. 876.)

Anodising in Wartime. (H. W: Wallbank, Metal Industry, Vol. 62, No. 2o, 14/5/43, pp. 314-316.)

Bibliography of Foreign Published Information on Protective Coatings (1, Protective CoatingsGeneral; 2, Electrolytic Oxidation; 3, Cladding; 4, Phosphate and Chromate Layers; 5, Electroplating and Polishing; 6, Metal Spraying; 7, Painting). (R.T.P.3, Bibliography No. 85, issued by the Ministry of Aircraft Production.)

534 10245 U.S.A. ... New Coatings Specifications Save Raw Materials. (Ind. Eng. and Chem. (News Ed.), Vol. 21, No. 6, March, I943, pp: 370-372.)

$535 \quad 10282$ U.S.A.

Summary of Protective Coatings, Raw Materials Situation. (A. C. Goetz, A.S.T.M., No. I21, March, 1943, pp. I 5-18.)

$536 \quad$ I0.390 G.B. ..

lating and Finishing. (Metal Industry, Vol. 62, No. 2 I, 2 I $/ 5 / 43$, p. $33^{2}$.)

$537 \quad 10487 \quad$ G. B. . .

Electrodeposition of Aluminium. (B. D. Ostrow, Metal Industry, Vol. 62, No. 22, 28/5/43, pp. 346-348.)

Welding (Heliarc, Gas, etc.).

$53^{8} \quad 9817$ U.S.A. $\quad$... The Temprite Spot Welder Cooler. (Autom. Ind., Vol. 88, No. 2, 15/1/43, p. 33.)

5399853 G. B. ... ... Developments in Flat-Fillet Welding Technique. (Mech. World, Vol. i 3 , No. 2,936, 9/4/43, p. 397.)

$540 \quad 9862$ G.B. ... utt Welding of High Speed Steel. (Airc. Eng., Vol. I 5, No. I7o, April, I943, p. 122.)

$5419962, G, B . \ldots$

$542 \quad 10047$ G.13. ...

The Gas Welding of Copper. (Metal Industry, Vol. 62, No. I9, 7/5/43, pp. 298-300.)

Oxy-Butane Welding. (Mech. World, Vol. I13, No. 2,934, 26/3/43, p. 333.)

543 101 20 G.B. ...

544 IоI 58 G.B. ...

$A$ Development in Welded Fabrication. (Mech. World, Vol. I I 3, No. 2,938, 23/4/43, p. 44I.)

Bronze Welding. (A. J. T. Eyles, Sheet Metal Industry, Vol. I7, No. I93, May, i943, pp. 874-875.)

545 I0I6I G.B. ...

Elin-Hafergut Welding Process. (R. F. Tylecote, Sheet Metal Industry, Vol. I7, No. r93, May, I943, pp. 878-879.)

546 roif2 G.B. ... ... Conservation of Arc Welding Electrode. (Sheet Metal Industry, Vol. r7, No. I93, May, 1943, p. 879.)

547 Ior63 Germany ... Automatic Arc Welding Without the Aid of Mechanical Appliances (Translation from the German). (G. Hafergut, Sheet Metal Industry, Vol. I7, No. 193, May, I943,'pp. 880-882.)

$548 \quad 1027^{2}$ U.S.A. ... Electronic Control for Aluminium Welding. (Aero Digest, Vol. 42, No. 3, March, I943, pp. 4.32-434.) 


\begin{tabular}{|c|c|c|}
\hline \multirow{2}{*}{$\begin{array}{c}\text { ITEM } \\
\text { No. } \\
549\end{array}$} & \multicolumn{2}{|c|}{$\begin{array}{l}\text { R.T.P. } \\
\text { REF. }\end{array}$} \\
\hline & 10275 & U.S.A. \\
\hline $55^{\circ}$ & 10334 & Canada \\
\hline $55^{I}$ & $1035^{I}$ & U.S.A. \\
\hline $55^{2}$ & I0395 & U.S.A. \\
\hline 553 & 10427 & U.S.A. \\
\hline 554 & 10484 & G.B. $\ldots$ \\
\hline 555 & 10512 & U.S.A. \\
\hline $55^{6}$ & 10514 & G.B. . \\
\hline
\end{tabular}

TITLE AND JOURNAL.

New Method Speeds Up Maintenance on Gas Welding and Flame Cutting. (Aero Digest, Vol. 42, No. 3, March, 1943, pp. 407-408.)

Gas Welding Flux in Glass Containers. (Canadian Av., Vol. I 5, No. 12, Dec., 1942, p. I40.)

Heliarc Welding Opens New Horizons in Aircraft Design and Construction (Magnesium W'elded Structures). (Aviation, Vol. 41, No. I I, Nov., 1942, pp. 147 and 323-324.)

Nitric-Hydrofluoric Bath for Removing Welding Flux from Aluminium Alloy Parts. (P. M. Craig, Autom. Ind., Vol. 88, No. 5, I/3/43, pp. 19 and 53.)

The Sciaky Portable Gun Welder. (Autom. Ind., Vol. 88, No. I, "I/1/43, p. 84.)

Welding with Al Bronze Welding Rods. (D. E. Swift, Metal Industry, Vol. 62, No. 22, 28/5/43,

p. 340.)
Structural Failure of All-Welded Tanker " Schenectlady"). (Engineer, Vol. 175, No. 4,558, 24/5/43, rp. 4'3-4I 4.)

$55^{6} \quad 10514$ G.B. ..

Air Operated Spot Welder. (Engineer, Vol. 175, No. $4,558,2$ I $/ 5 / 43$, pp. 41 4-4I 5.)

Milling, Grinding, Machining, etc.

5579925 G.B. ... ... Preventing Breakages of Milling Cutters. (Ma-

$\begin{array}{ccc}55^{8} & 9990 & \text { Canada } \\ 559 & \text { ror } 23 & \text { G.B. ... } \\ 560 & \text { ror } 24 & \text { G.B. ... } \\ 5^{61} & \text { ror64 } & \text { G.B. ... }\end{array}$
chinery, Vol. 62, No. 1,588, 18/3/43, p. 293.)

High Speed Vertical Milling. (Commercial Aviation, Vol. 4, No. 12, Dec., 1942, pp. 88-89.)

Grinding and Inspection of Tool Steels. (Machinery, Vol. 62 , No. $1,593,22 / 4 / 43$, p. 428 .)

Machining with Coated Abrasive8. (Machinery, Vol. 62, No. I, 593, 22/4/43, p. 429.)

Rolling, Processing and Testing of TinplatePickling Practice (Contd.). (W. E. Hoare and E. S. Hedges, Sheet Metal Industry, Vol. I7, No. 193, May, 1943, pp. 791-799.)

$5_{62}$ IoI6 $_{5}$ G.B. ... . .. Cold and Hot Rolling of Metals (Contd.). (R.T.P. Translation No. I,735.) (O. Enicke and K. H. Lucas, Sheet Metal Industry, Vol. 17, No. 193, May, 1943, pp. 800-804.)

$5^{6} 3{ }_{102} 5^{8}$ U.S.A. ... Free Machining 36 per cent. Nickel Alloy ("Invar"). (G. V. Luerssen, Aero Digest, Vol. 42, No. 3, March, 1943, pp. 229-23r.)

$5641049^{2}$ G.B. ... ... Surface Finish and Function of Parts (with Discussion). (G. Schlessinger, Vol. 175, No. 4,559, $28 / 5 / 43$, pp. $429-430$ and $434-436$.)

Soldering and Brazing.

$5^{65} \quad 97^{85} \quad$ U.S.A. $\quad$.. Brazing-Data Sheet No. 4. (Metal Progress, Vol. 42 , No. 5, Nov., 1942, p. 823.)

$566995^{8}$ G.B. ... ... Tongs for Silver Brazing. (Metal Industry, Vol. 62, No. 19, 7/5/43, p. 294.) 
ITEM R.T.P.

No. REF.

567 IоI94 G.B. ...

568 Iо386 G.B. ...

5699793 U.S.A.

5709799 U.S.A.

$57^{\text {I }}$ IOI 2 I G.B. .

572 roi6o G.B. ...

573 I0579 U.S.A.

$57410_{5} 80$ U.S.A.

57510581 U.S.A.

$57^{6} \quad 1035^{\circ}$ U.S.A.

$577 \mathrm{IO}_{3} 83$ G.B. ...

$578 \quad 10396 \quad$ U.S.A.

57910036 U.S.A.

$580 \quad 10037$ U.S.A

581 10039 U.S.A.

582 roI68 G.B. ...

583 IоI69 G.B. .
TITLE AND JOCRNAL.

Non-Corrosive Soldering Fluxes. (H. Silman and W. Stein, Metal Industry, Vol. 62, No. 20, I 4/5/43, pp. 306-308.)

Non-Corrosive Soldering Fluxes (Contd.). (H. Silman and $W$. Stein, Metal Industry, Vol. 62, No. $21,21 / 5 / 42$, pp. 325-327.)

Cutting and Cutting Tools.

Cutting of Steel and Cutting Tools. (Metal Progress, Vol. 42, No. 5, Nov., r942, pp. 887-888.)

Tool Bits for Cutting Hard Metals. (Metal Pro- gress, Vol. 42, No. 5, Nov., I942, p. 946.)

Small Quantity Gear Cutting. (Mech. World, Vol. 1 I 3 , No. $2,938,23 / 4 / 43$, pp. 448-45o.)

Machine Oxygen Cutting. (Sheet Metal Industry. Vol. I7, No. 193, May, I943, p. 877.)

Carbide Cutters v. High Speed Steel. (H. A. Oldenkamp and J. McFadyn, Mech. Eng., Vol. 65, No. 4, April, 1943, pp. 253-256.)

Cutting Metals from the Users' Point of View. (L. B. Dorsner, Mech. Eng., Vol. 65, No. 4, April, 1943, pp. 257-258.)

A Method of - Meeting Cutting Tool Material Problems. (H. A. Tobey, Mech. Eng., Vol. 65, No. 4, April, 1943, pp. 259-260.)

Dies and Casting.

Fabricating Plastic Dies for Acrylate Sheets. (K. L. Leeg, Aviation, Vol. 4I, No. I I; Nov., 1942, pp. I 43-145 and 336.)

Relative Characteristics of Non-Ferrous Casting Techniques. (Metal Industry, Vol. 62, No. 21, 25/5/43, pp. 322-324.)

Some, Recent Developments in Sheet Metal Fabrication (Dies, etc.). (P. L. Smith and V. L. Brooks, Autom. Ind., Vol. 88, No. 5, 1/3/43, pp. 22-23 and 53.)

Moulding.

Injection Moulded Thermosetting Parts. (H. R. Morse, Modern Plastics, Vol. 2o, No. 3, Nov., I 942, pp. 4I-43 and I 28-I34.)

Moulding with Non-Critical Materials. (C, P. Morgan, Modern Plastics, Vol. 2o, No. 3, Nov., I942, pp. 60-6r.)

Cold Moulding Impact Material Preforms. (Modern Plastics, Vol. 20, No. 3, Nov., 1942, pp. 78 and I 8 .)

Etching, Drop Stamping.

Drop Stamping Practice. (A. T. Pierce, Sheet Metal Industry, Vol. 17, No. 193, May, 1943. pp. $83 \mathrm{I}-\mathbf{8}_{3} 8$.)

Etching on Métals-Details of Neiw Method. (Sheet Metal Industry, Vol. I7, No. 193, May, I943, p. 836 .) 

R.T.P.

No. REF.

$584 \quad$ 10384 G.B. . .

TITLE AND JOURNAL:

Plastic Punches for Drop Stamping. (Metal Industry, Vol. I62, No. 21, $21 / 5 / 43$, p. 324.)

Rivets and Riveting.

$5^{85} \quad 10245$ U.S.A

Super-Hard Rivets to Replace Bolts (Hi Shear Rivet). (Ind. and Eng. Chem. (News Ed.), Vol. 21, No. 26, March, I943, p. 424.)

$586 \quad 103^{20}$ Canada

Electric Gun for Riveting. (Flying, Vol. 32, No. 3, March, 1943, p. 94.)

Spinning, Forge-Piercing.

$5^{87} \quad 9998 \quad$ U.S.A.

$588 \operatorname{loo}_{56}$ G.B. ...

Tube Spinning and Necking Operations Developed by the New Wolverine "Spun End Process." (Autom. Ind., Vol. 88, No. 4, I 5/2/43, p. 39.)

Accuracy in Forge Piercing. (Mech. World, Vol. I I , No. 2,93 r, 5/3/43, p. 249.)

Machines and Machine Tools.

5899819 U.S.A.

.. The Holly Tube Bender. (Autom. Ind., Vol. 88, No. 2, 15/1/43, p. 37.)

$590 \quad 9924$ G.B. ...

Tool Angles, Feeds, Speeds, etc., for Machining with Cemented Carbide Tools. (Machinery, Vol. 62, No. I, $588,18 / 3 / 43$, p. 297.)

$591 \mathrm{I} 0044$ G.B. ...

A New Carbide Tipped Tool. (Mech. World, Vol. I I 3 , No. 2,934, 26/3/42, pp. 323-324.)

$59^{2}$ IOI 57 G.B. ...

59310226 G.B. ...

594 10270 U.S.A.

$595 \quad 10345$ U.S.A.

$596 \quad 10365$ U.S.A.

59710408 G.B. ...

598 10421 U.S.A.

The. Development of Carbide Tipped Tools. (Sheet Metal Industry, Vol. I7, No. 193, May, 1943,

pp. 863-864.)
Magnetic Skimmer for Removing Ferrous Particles. (Engineer, Vol. I75, No. $4,557,14 / 5 / 43$, p. 393.)

Rivet Sorting Machines. (Aero Digest, Vol. 42, No. 3, March, 1943, pp. 370 and 406.)

Range of Drop Hammer Operations. (C. J. Frey and S. S. Kogut, Aviation, Vol. 41, No. II, Nov., 1942, pp. I I 8-1 2 I and 340.)

Power Presses (Die Cushion Size ard Ring Holding Pressure Required). (Aviation, Vol. 4I, No. II, Nov., 1942, pp. 161-163.)

Magnetic Skimmer for Swarf Removal. (Engineering, Vol. I 55, No. 4,036, $21 / 5 / 43$, p. 406.)

North American New Boring Tool. (Autom. Ind., Vol. 88, No. 1, I/1/43, pp. 42 and 72 .)

C. Inspection.

Testing, Crack Detection.

$599 \quad 985^{I} \quad$ G.B. . .

600 rol10 G.B. ...

601 IOI67 G.B. ...

Testing Heat Insulating Materials at the N.P.L. (Mech. World, . Vol. I I3, No. 2,936, 9/4/43, p. $3^{82 .)}$

Testing the Wall Thickness of Intricate Castings. (B. M. Thornton, Engineering, Vol. 150, No. $4,034,7 / 5 / 43$, p. 36 r.)

The Testing of Continuity of Thin Tin Coatings on Steel. (R. Kerr, Sheet Metal Industry, Vol. I7, No. 193, May, I943, pp. 817-818 and 825.) 


\begin{tabular}{|c|c|c|}
\hline $\begin{array}{c}\text { ITBM } \\
\text { No. }\end{array}$ & \multicolumn{2}{|c|}{$\begin{array}{l}\text { R.T.P. } \\
\text { RIEF. }\end{array}$} \\
\hline 602 & $\mathrm{IO}_{4} \mathrm{I}_{4}$ & $\mathrm{G} \cdot \mathrm{B}$ \\
\hline 603 & 10483 & G.B. \\
\hline 604 & $105^{2} 3$ & G.B. \\
\hline 605 & 10525 & Gill. \\
\hline 606 & I0544 & G.B. \\
\hline 607 & 10586 & U.S.A. \\
\hline 608 & $99^{23}$ & G.B. \\
\hline 609 & 9927 & G.B. \\
\hline 610 & 9956 & G.B. \\
\hline 611 & 10387 & G.13. \\
\hline 612 & 10392 & \\
\hline
\end{tabular}

613 lofi2, (i.B. ...
TITLE AND JOURNAL.

Crack Detection in Non-Ferrous Materials (Hyglo System). (Nature, Vol. I5 I, No. 3,837, I5/5/43, p. 555.)

Modern Methods, of Metallurgical Analysis. (E. A. Liddiard, Metal Industry, Vol. 62, No. 22, $28 / 5 / 43$, pp. $33^{8-340 .)}$

The Mechanical Testing of Materials with Special Reference to the Testing of Welds. (V. E. Green, Engineering Inspection, Vol. 8, No. 1, Spring, I943, pp. 24-28 and 36 .)

The Fabrication and Testing of Fusion Welded Pressure Vessels. (S. H. Griffiths, Engineering Inspection, Vol. 8, No. I, Spring, I943, pp. 4-23.) Magnetic Crack Detection in Welded Structures. (Airc. Eng., Vol. i 5, No. I7I, May, 1943, p. 152.) Chart Giving Various Systems for Designating Surface Roughness. (Mech. Eng., Vol. 65, No. 4, April, r943, p. 285.)

$X-R a y$ Analysis.

The Use of Infra-Red Rays. (Machinery, Vol. 62, No. $1,588,18 / 3 / 43$, p. 287 .)

Portable X-Ray Unit. (Machinery, Vol. 62, No. I, 588, I8/3/43, p. 300.)

X-Ray Crystal Analysis. (Metal Industry, Vol. 62, No. 19, $7 / 5 / 43$, pp. 29o-292.)

X-Ray Analysis in Industry (Symposium of Papers). (Metal Industry, Vol. 62, No. 21, $21 / 5 / 43$, p. 327.) X-Rays and Light Metallurgy (Book). (E. J. Tunnicliffe, issued by Siemens-Schuckert, Ltd.) (Available in R.T.P.3, Ministry of Aircraft Production.)

X-Ray Analysis. (L. Bragg, Nature, Vol. I5 I, No. 3,837, I $5 / 5 / 43$, pp. $545-547$.)

\section{Instruments.}

Flight.

6r+ rozor Germany ... Fvaluation of Time Records by the Simultaneous Employment of Instruments of Different Types. (H. Knoblock, L.F.F., Vol. '20, No. 2, 27/3/43, pp. 42-45.)

$\begin{array}{ccc}615 & 1035^{2} & \text { U.S.A. } \\ 616 & 1037^{2} & \text { U.S.S. }\end{array}$

Flight Recorder to Ease Test Pilot's Job. (Aviation, Vol. 4 I, No. I I, Nov., I942, p. I 49.)

Simplified Computors' Aid Navigation. (P. V. H. Weems, Aviation, Vol. 4I, No. I I, Nov., I942, pp. 233-234.)

617 I0595 Canada

New Flight Test Recorder. (1. C. Thomas, Flying. Vol. 32, No. 5, May, I943, pp. 60-6i, 169.)

Electrical.

618 9858, Germany ‥ Electrical Measurement of Stresses. (R.T.P.3 Translation. No. I,6I5.) (H. Theis, Airc. Eng.. Vol. I.5, No. I 7o, April, 1943, pp. I06-109.) 


\begin{tabular}{|c|c|c|}
\hline $\begin{array}{r}\text { ITEM } \\
\text { No. }\end{array}$ & & $\begin{array}{l}\text { T.P. } \\
\text { BEF. }\end{array}$ \\
\hline 619 & IOI 4I & G.B. $\ldots$ \\
\hline 620 & 10142 & G.B. \\
\hline 623 & 10502 & U.S.A. \\
\hline 624 & IO45 I & G.B. $\ldots$ \\
\hline 625 & 10505 & U.S.A. \\
\hline 626 & 9861 & G.B. $\ldots$ \\
\hline 627 & 9906 & G.B. $\ldots$ \\
\hline 628 & 10000 & U.S.A. \\
\hline 629 & IOI I 5 & U.S.A. \\
\hline $63^{\circ}$ & 10406 & G.B. $\ldots$ \\
\hline $63 \mathrm{I}$ & 10431 & U.S.A. \\
\hline
\end{tabular}

TITLE AND JOURNAL.

The Law of the Moving-Iron Instrument. (G. F. Tagg, J. Inst. Elect. Engs., Vol. 9, No. I3, Feb., 1943, pp. 65-72.)

Theory of the Force or Torque of Soft Iron Electrical Instruments. (C. V. Drysdale, J. Inst. Elect. Engs.; Vol. 9, No. I3, Feb., 1943, pp. 79-83.)

Electric Extensometer. (Sci. Am., Vol. 168, No. 3, March, 1943, p. 1 26.)

Flow Meters.

An Air Flowmeter for Rates of Flow. (L. Rosenfield, I.A.E. Reports, No. 1,943-1,945, 24/3/43, p. $3^{6 .)}$

Electric Fuel Floumeter. (Sci. Am., Vol. r68. No. 3, March, 1943, pp. 133-134.)

Miscellaneous.

Precision Instruments for Engineers. (Airc. Eng., Vol. 15, No. 170, April, 1943, pp. 1 20-1 21 .)

New British Procision Measuring Instruments. (Autom. Eng., Vol. 33, No. 434, March, 1942, pp. 123-1 25.)

New Apparatus for Vibration Studies. (Autom. Ind., Vol. 88, No. 4, I 5/2/43, pp. $44-45$ and 90.)

The Rolling Ball Viscometer. (R. M. Hubbard and G. G. Brown, Ind. and Eng. Chem. (Anal. Ed.), Vol. 15, No. 3, 15/3/43, pp. 212-218.)

Stroboscopic Equipment. (G. Windred, Engineering, Vol. I 55, No. 4,036, May 21, 1943, pp. 401-402.)

Mass Spectrometer for Quantitive Analysis of Refinery Gases. (Nat. Pet. News, Vol. 35, No. I $2,24 / 3 / 43$, P. I 4 .)

\section{Production.}

Organisation and Control.

$63^{2} 9860$ G.B. ...

Quality Control in Production Engineering. ( $\mathrm{H}$. Rissik, Airc. Eng., Vol. 15, No. 170, April, 1943, pp. I 15-1 I9 and I2I.)

63310064 U.S.A. ... War Production in 1943. (L. R. Boulware, Mech. Eng., Vol. 65, No. 2, Feb., 1943, p. 99.)

63410075 U.S.A.

Organisation as a Project in Human Engineering. (P. Pigors, Mech. Eng., Vol. 65, No. 1, Jan., I943, pp. 40-41.)

635 Iогі2 G.B. ... ... Plant Maintenance. (Engineering, Vol. I 55, No. $4,034,7 / 5 / 43$, p. $37^{2}$.)

$63^{6}$ IоI 6 G.B. ...

Running Trials and Acceptance Tests in a Neu Factory. (J. V. Brittain, Mech. World, Vol. I13, No. $2,938,23 / 4 / 43$, pp. 43 I-432.)

637 Iогі9 G.B. ... ... Production Efficiency Reports. (G. Lowe, Mech. World, Vol. I1 3 , No. 2,738, 23/4/43, pp. 439-440.) 


\begin{tabular}{|c|c|c|}
\hline $\begin{array}{c}\text { ITEM } \\
\text { No. }\end{array}$ & \multicolumn{2}{|c|}{$\begin{array}{l}\text { R.'T'R' } \\
\text { MLIF. }\end{array}$} \\
\hline 638 & 10128 & G.[3. ... \\
\hline 639 & Jo Ig8 & G.B. ... \\
\hline 640 & $\operatorname{IO} 242$ & $G .13 . \ldots$ \\
\hline 641 & 10257 & U.S.I. \\
\hline 642 & 10267 & Germany \\
\hline 643 & 10290 & $(i, 13, \ldots$ \\
\hline 644 & 10380 & U.S.A. \\
\hline 64.5 & 10417 & U.S.A. \\
\hline 646 & 10419 & U.S.A. \\
\hline 647 & $1052 t$ & G.B. $\ldots$ \\
\hline
\end{tabular}

TITLE AND JOURNAL.

'ontrol of Rau Materials. (Nature, Vol. ‘5ı, No. $3,833,17 / 4 / 43$, pp. 452-453.)

Production Control Booklet, issued by British Stan dards Inst., B.S.I. 100, Pt. I (ig43). (Metal. Industry, Vol. 62, No. $20,{ }^{\prime} 4 / 5 / 43$, p. $\left.3^{1} 3.\right)$

Post-War Reconstruction Employers' Need for Organisation. (Engineering, Vol. I 55, No. 4,035, I 4/5/43, pp. $3^{83-3^{84}}$.)

C'urtiss-Wright's Shop Priority Control Systeme. (W. J. Shepherd, Aero Digest, Vol. 42, No. 3. March, 1943, pp. $216-220$ and 382.)

Directory of Aircraft Manufacturers. (Aero Digest, Vol. 42, No. 3, March, 1943; pp. $283-362$ and 424.)

High Speed in the Wartime Production Shop. $\cdot G$. Schlesinger, J. Inst. Prod. Engs, Vol. 22, No. 4. April, 1943, pp. 137-167.)

Sub-Contracting as a Permanent Policy. (Aviatıon, Vol. 4I, No. II, Nov., I942, pp. I89 and $\left.33^{6}-339.\right)$

Quality. Control at Bendix. (J. Geschelin, Autom. Ind., Vol. 88, No. I, I/I/43, pp." I 8-23 and 44.)

Conservation of Critical Materials, Man-Hours $v$. Machine Time. (Autom. Ind., Vol. 88, No. I, $1 / 1 / 43$, pp. $26-29$ and 64. )

1 Brief Summary of Some Simpie Methods of Quality Control. (A. S. Wharton, Engince:ing Inspection, Vol. 8, No. I, Spring, I943, pp. 29-36.)

$648 \quad 10.543 \quad$ (i.B. ...

Sampling Inspection and Quality Determination. (H. Rissik, Airc. Eng., Vol. I5, No. I71, May, I 943, pp. I 49-I 52.)

Research and Training.

649 y805 Canida ... Training New Workers in the Aircruft Industry. (E. W. Lloyd, Canadian Aviation, Vol. 16, No. I, Jan., I943, pp. 76-78.)

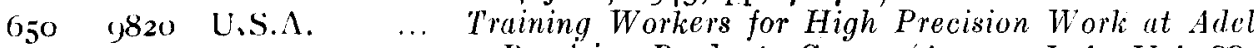
Precision Products Corp. (Autom. Ind.; Vol. 88, No. 2, 15/1/43, pp. 30-31, 80 and 81.)

$651 \quad 965 \quad$ (i.B. . .

$65^{2} \quad \operatorname{loog}_{3}$ U.S.S.

University Education and Rescarch in Amorica. (Engineer, Vol. I75, 4,556, 7/5/43, pp. 375-376.)

The New Curtiss-Wright Research Laboratory (uith Photographs of Altitude. Chamber). (Curtiss Flyleaf, Vol. 25, No. 4, Sept.-Oct., 1942, pp. 2 1-23.)

65310070 U.S.A.

Industrial Psychology-Industrial Relations. (I. Knickerbocker, Mech. Eng., Vol. 65, No. 2, Feb., r943, pp. 1 $37^{-1} 3^{8 .)}$

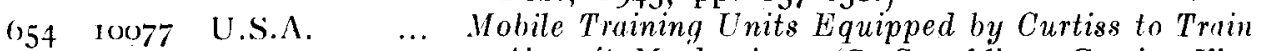
Aircraft Mechanics. (S. Spaulding, Curtiss Ii)yleaf, Vol: 25 , No. 5, Nov,-Dec., 1942, pp. 3-5.)

65510223 G.B. ... ... Hducation and Training for Engineers. (Abstract of Memorandum Issued by the Institution of Electrical Engineers.) (Engineer, Vol. I75, No. 4,557, I $4 / 5 / 43$, p. $3^{89}$.) 


$\begin{array}{ccc}\text { ITEM } & \text { R.T.P. } \\ \text { No. } & \text { REF. } \\ 656 & 10413 & \text { India } \\ 657 & 10428 & \text { G.B. ... } \\ 658 & 10517 & \text { G.B.... } \\ 659 & 10518 & \text { G.B. . . } \\ 660 & 10548 & \text { G.B. ... } \\ 66 \text { I } & 10578 & \text { U.S.A. }\end{array}$

TITLE AND JOURNAL.

Science in India (Resources, etc.). (D. N. Wadia, Nature, Vol. 15I, No. 3,837, I5/5/43, pp. 548-55I.)

Practical Points on Training Welders. (W. J. Thaw, Mech. World, Vol. I13, No. 2,941, I4/5/43, pp. 517-519.)

Conservation of Scientific and Technical Periodicals. (Nature, Vol. I5I, No. 3,836, 8/5/43, pp. $5^{\text {I 2-5 } 3 \text {.) }}$

News and Views from the Scientific Front. (R. Gregory, Nature, Vol. I5I, No. 3,836, 8/5/43, pp. $5^{17-5}$ I9.)

Education for Industry. XIV, Chemists' Training and Entry. (Trade and Engineering Times, Vol. 52, No. 95, April, 1943, p. 23.)

The American Engineer and the War Effort. (A. A. Potter, Mech. Eng., Vol. 65, No. 4, April, 1943, pp. $25^{\mathrm{I}-2} 5^{t}$ and $25^{8}$.)

Aircraft Production Methods.

6629800 Canada ... Assembly Line of Harvard Advanced Traincr. (R. E. Crawford, Canadian Aviation, Vol. IG, No. I, Jan., I943, pp. 39-43.)

$663987^{2}$ U.S.A. $\quad \ldots \quad$ Mass Production at the Consolidated Aircraft Corp. (Photograph). (Am. Av., Vol. 6, No. $17, \mathbf{1} / \mathbf{2} / 43$, p. 52.)

6649875 U.S.A. $\quad$.. Canadian Aircraft Production. (Am. Av., Vol. 6, No. $17,1 / 2 / 43$, p. $5^{6 .)}$

665988 I U.S.A.

Glenn Martin P.B.M.-3 Mariners on the Assembly Line (Photograph). (Am. Av., Vol. 6, No. I6, I $5 / \mathrm{i} / 43$, p. 48 .)

6669884 U.S.A. $\quad$... Mass Production of Waco CG-4A Gliders (Photograph). (Am. Av., Vol. 6, No. I6, 1.5/1/43, p. $5^{\text {I.) }}$

6679885 U.S.A. $\quad$.. Mass Production of Grumman Fighters. (Am. Av., Vol. 6 , No. $16,15 / 1 / 43$, p. 54.)

6689982 U.S.A. $\quad \ldots$ Ford's 15-Passenger Troop Carrying Gliders and New Glueing Process in Their Manufacture. (Am. Av., Vol. 6, No. 20, $15 / 3 / 43$, p. 5o.)

669 roo22 U.S.A. ... A Method of Applying Production Design to Aircraft. (H. Harrison, S.A.E. Preprint, Nat. Aeron. Meeting, April 8-9, 1943.)

670 10252 U.S.A. .. Aircraft Industry in Latin America. (W. R. - Douglas, Aero Digest, Vol. 43, No. 3, March, 1943, pp. I I 8-1 20 and 400-403.)

$67 \mathrm{r} 10255$ U.S.A. $\quad$... lofting Problems of Streamline lbodics (Pt. II). (C. M. Hartley and R. A. Liming, Aero Digest, Vol. 42, No. 3, March, 1943, pp. 185-192 and $3^{80 .)}$

$67^{2}$ I'256 U.S.A. ‥ Fabrication of Aircraft Surfaces on Moving Assembly Lines. (F. M. Reck, Aero Digest, Vol. 42, No. 3, March, 1943, pp. 207-215.) 


\begin{tabular}{|c|c|c|c|c|}
\hline $\begin{array}{c}\text { ITEM } \\
\text { No. }\end{array}$ & & $\begin{array}{l}\text { T.P. } \\
\text { IEF. }\end{array}$ & & TITLE AND JOURNAL. \\
\hline 673 & 10295 & Canada & $\ldots$ & $\begin{array}{l}\text { Assembly Line Construction of YAKI-26 Single- } \\
\text { Seater Interceptors (Photograph). (Flying, Vol. } \\
\text { 32, No. 3, March, 1943, p. 25.) }\end{array}$ \\
\hline 674 & 10303 & $(i, B, \ldots$ & $\cdots$ & $\begin{array}{l}\text { Luncastor Production. (Flying, Vol. } 32 \text {, No. } 3 \text {, } \\
\text { March, 1943, p. 4r.) }\end{array}$ \\
\hline 67.5 & 10321 & Canadia & $\cdots$ & $\begin{array}{l}\text { Assembly Line of AT-x6 Advanced Trainers (Photo). } \\
\text { (Canadian Av., Vol. I5, No. 12, Dec., 1942, } \\
\text { p. 55.) }\end{array}$ \\
\hline 676 & 10322 & G.B. ... & $\ldots$ & $\begin{array}{l}\text { De Havilland's Production of New" "Mosquito." } \\
\text { (Canadian Av., Vol. 15, No. 12, Dec., 1942, pp. } \\
\text { 6o-61 and Ioc.) }\end{array}$ \\
\hline 677 & 10323 & Canada & $\ldots$ & $\begin{array}{l}\text { Fairchild " Comell" Trainer (Prodnction). (Cana- } \\
\quad \text { dian Av., Vol. I5, No." I 2, Dec., 1942, pp. 62-63.) }\end{array}$ \\
\hline${ }_{67} 8$ & 10324 & U.S.A. & $\cdots$ & $\begin{array}{l}\text { Boeing's at Work on New Catalina: (Canadian Av., } \\
\text { Vol. I 5, No. I } 2 \text {, Dec., 1942, pp. 64-65.) }\end{array}$ \\
\hline 679 & $103^{2} 5$ & Canada & $\ldots$ & $\begin{array}{l}\text { Consolidated Catalina Manufactured by Canadian } \\
\text { Vickers (Photo). (Canadian Av., Vol. I5, No. } \\
\text { I2, Dec., 1942, pp. } 7^{1-72} \text { and 98-99.) }\end{array}$ \\
\hline 680 & 10326 & G.I3. ... & $\ldots$ & $\begin{array}{l}\text { Lancaster Components Manufactured by Ottawa } \\
\text { Car, Ltd. (Canadian Av., Vol. 15, No. 12, Dec., } \\
\text { 1942, p. 74.) }\end{array}$ \\
\hline 681 & 10393 & U.S.A. & $\ldots$ & $\begin{array}{l}\text { The Production of Giant Planes. (H. Woodhead, } \\
\text { Autom. Ind., Vol. } 88 \text {, No. 5, 1/3/43, pp. } 9 \text { and } \\
\text { 50-5I.) }\end{array}$ \\
\hline 682 & IO4OI & U.S.S.R. & ... & $\begin{array}{l}\text { Yak-1 (I-26) Fighters on the Assembly Line. } \\
\text { (Autom. Ind., Vol. 88, No. 5, } 1 / 3 / 43, \text { pp. } 9 \text { and } \\
\text { 50-51.) }\end{array}$ \\
\hline 683 & 10403 & U.S.A. & $\ldots$ & $\begin{array}{l}\text { Power-Driven Assembly Line Applied to Aircraft } \\
\text { Fabrication (Photograph). (Autom. Ind., Vol. 88, } \\
\text { No. 5, I/3/43, p. 40.) }\end{array}$ \\
\hline 684 & IO49I & U.S.A. & $\cdots$ & $\begin{array}{l}\text { North American Aircraft Assembly Plant at Texas. } \\
\text { (Engineer, Vol. I75, No. 4,559, 28/5/43, pp. } \\
\text { 425-426.) }\end{array}$ \\
\hline 685 & ${ }_{10} 8^{87}$ & Canada & $\ldots$ & $\begin{array}{l}\text { Willow Run Aircraft Plant. (R. Stewart, Flying, } \\
\text { Vol. } 3^{2} \text {, No. 5, May, I943, pp. } 2 \mathrm{I}_{-2} 3 \text { and } 5^{\circ} \text { ) }\end{array}$ \\
\hline \multicolumn{5}{|c|}{ Engines, Propellers Production Methods. } \\
\hline 686 & 9814 & U.S.A. & $\ldots$ & $\begin{array}{l}\text { One-Piece Hollow Steel Propeller Blades (Produc- } \\
\text { tion Methods). (J. Geschelin, Autom. Ind., Vol. } \\
\text { 88, No. } 2, \pm 5 / \mathrm{I} / 43 \text {, pp. I8-22.) }\end{array}$ \\
\hline 687 & $984 \mathrm{I}$ & U.S.A. & $\ldots$ & $\begin{array}{l}\text { Assembly Line Units Facilitate Handling of Radial } \\
\text { Engine.s. (Am. Av., Vol. 6, No. II, I/1 I/42, } \\
\text { p. 39.) }\end{array}$ \\
\hline 688 & 9995 & U.S.A. & $\cdots$ & $\begin{array}{l}\text { Mass Production of Stromberg Injection Carburet- } \\
\text { tor. (J. Geschelin, Autom. Ind., Vol. 88, No. } 4 \text {, } \\
\text { 15/2/43, pp. 18-22.) }\end{array}$ \\
\hline 689 & IO353 & U.S.A. & $\cdots$ & $\begin{array}{l}\text { Short Cuts Speed Propeller Production. (Aviation, } \\
\left.\text { Vol. 4I, No. I I, Nov., I } 94^{2} \text {, pp. I } 5^{1} \text { and } 320 .\right)\end{array}$ \\
\hline 690 & 10398 & U,S,A. & $\cdots$ & $\begin{array}{l}\text { Mass Production of Aircraft Engine Cylinder Heads } \\
\text { (Casting Processes, etc.). (Autom. Ind., Vol, 88, } \\
\text { No. 5, I/3/43, pp. } 26-29 \text { and 47.) }\end{array}$ \\
\hline
\end{tabular}


ITEM R.T.P.

No. RKF.

TITLE AND JOURNAL.

General Methods and Equipment.

69. 8969 U.S.A. $\quad$... Gang Riveting-A New Method of Rineting Employed by Curtiss Wright Corporation. '(Curtiss Flyleaf, Vol. 25, No. 4, Sept.-Uct., 1942, p. 19.)

6929900 U.S.A. New Technique for Producing Formed Parts in - Sheet Metals (Cecostamping). (Autom. Eng., Vol. 33, No. 434, March, 1942, pp. 104-106.)

6939922 G.B. ... The Manufacture of Nose Containers for Mortar Bombs. (Machinery, Vol. 62, No. $1,588,18 / 3 / 43$, pp. 281-285.)

6949957 G.B. . .

Importance of Sand Control in Foundry Work. (F. A. Allen, Metal Industry, Vol. 62, No. 19, 7/5/43, pp. 293-294.)

6959987 Canada

Forged Cylinder Heads and New Rapid Techniques in Manufacture. (Commercial Aviation, Vol. 4, No. 12, Dec., 1942, p. 74.)

6969988 Canada

Reproduction of Templates by the Transphoto. Process. (Commercial Aviation, Vol. 4, No. 12, Dec., 1942, pp. 75-76.)

$6979996 \quad$ U.S.A.

Position Charts to Heip Inexperienced Workers (Details given of Parts, Tools Required, etc.). (Autom. Ind., Vol. 88, No. 4, $15 / 2 / 43$, p. 23.)

698 sол66 G.B. ...

Plant and Process Problems (Contd.).

(D. G. P. Patterson, Sheet Metal Industry, Vol. I7, No. I93, May, 1943, pp. 803-807.)

$699 \cdot 10193$ U.S.A.

Possible Industrial Utilization of Starch Esters. (J. W. Mullen and E. Paesu, Ind. and Eng. Chem., Vol. 35, No. 3, March, 1943, pp. 381-384.)

$700 \quad 10266$ Germany Production Short Cuts (Rivet Squeezer, Lofting Device, Router, etc.). (Aero Digest, Vol. 42, No. 3, March, 1943, pp. 272-278.)

701 $1033^{2}$ U.S.A.

Tube Bending in Bell Aircraft, Ltd. (Canadian Aviation, Vol. I5, No. I2, Dec., 1942, pp. I 24 - I 28.)

$7^{\circ} 210333$ U.S.A. ‥ Removal of Broken Brills, Reamers, etc., from Drilled Holes (Pratt and Whitney Aircraft). (Canadian Aviation, Vol. I5, No. 12, Dec., 1942, pp. $13^{\mathrm{O}-\mathrm{I}} 3^{8}$.)

Welding in Production.

7039848 G.B. ... ... The Practical Control of Quality in Welding. (W. J. Thaw, Mech. World, Vol. II5, No. 2,926, 9/4/43, pp. $375-378$.)

70410246 U.S.A. ... Improved Goggles for Flame Welders. (Ind. and Eng. Chemistry (News Ed.), Vol. 21, No. 6, March, 1943, p. 418.)

70.510254 U.S.A. . .. Arc Welding Aircraft Structures (Part II). (W. S. Evans, Aero Digest, Vol. 42, No. 3, March, 1943, pp. $177^{-183}$.)

706 I028I U.S.A. ... Northrop's Heliarc Welding Process for Magnesium. (U.S. Air Services, Vol. 27, No. I2, Dec., 1942, pp. $42-44$.) 


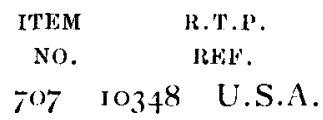

TITLE ATD JOURNAL.

Maintenance and Inspection Routine Servicing and Repair of Arc Welding Equipment. (R. F. Wycr, Aviation, Vol. 4I, No. II, Nov., 1942. pp. $133^{-1} 3^{6}$ and $3^{28-33}$.)

Machine. Tools.

The Steinle Centreless Thread Generator. (Machinery, Vol. 62, No. I,593, 22/4/43, pp. 430-434.) Maintenance Steps to Prolong Instrument Life. (T. A. Cohen, Aero Digest, Vol. 42, No. 3, March, 1943, pp. 244-251.)

Vultee Automatic Rivet Injector. (Aero Digest, Vol. 42, No. 3, March, 1943, pp. 406-407.)

Tool Design and the Use of Isometric Drauings for Speeding Production. (J. J. Scheppe, Aviation, Vol. 4I, No. II, Nov., 1942, pp. I 29 and 280.)

War Plants.

New Clinip Assembly Plant in Arizona. (Am. Av., Vol. 6, No. I1, 1/1 1/42, p. 56.)

Successful Camouflage for U.S. W'ar Plants and Army Installations Developed by U.S. Army Engineers. (Am. Av., Vol. 6, No. I I, I/1 I/42, p. 47.)

The Willow Run Bomber Plant. (Machinery, Vol. 62. No. 1, 593, 22/4/43, pp. 421-427.)

Method of Fire Hazard (Classification of Building Materials). (A. J. Steiner, A.S.T.M. Bulletin, No. I2 I, March, 1943, pp. 19-22.)

Complete Conversion of Automotive Plant to Production of Aircraft (General Motors) (Photo). (U.S. Air Services, Vol. 28, No. 2, Feb., 1943, p. 33.)

\section{Salvage.}

Segregation and Reclamation of Scrap. (L. S. Deitz, Metal Industry, Vol. 62, No. 19, 7/5/43 pp. 295-206.)

Vegas Scrap Conservation Programme. (Autom. Ind., Vol. 88, No. 4, I5/2/43; pp. $3^{6-37}$ and 84-88.)

Curtiss Wright Salvage Scheme. (Curtiss Flyleaf, Vol. 25, No. 4, Sept.-Oct., 1942, pp. 8-9.)

The Reclamation of Porous Castings (Technical Bulletin, April, 1943). (E. J. H. Jones, J. Inst. Prod: Engs., Vol. 22, No. 4, April, 1943.)

Scrap-Saving Methods Support the War Effort. (B. D. Kunkle, Mech. Eng., Vol. 65, No. 4, April, 1943, pp. 267-273.)

Workers' Welfare.

Indirect Mercury Lighting in Industrial Plants. (Am. Av.. Vol. 6, No, I i, I/1 1/42, p: 39.) 


\begin{tabular}{|c|c|c|}
\hline $\begin{array}{l}\text { ITEM } \\
\text { NO. }\end{array}$ & \multicolumn{2}{|c|}{$\begin{array}{l}\text { R.T.P. } \\
\text { REF. }\end{array}$} \\
\hline 723 & 9926 & G.B. $\ldots$ \\
\hline 724 & 10050 & U.S.A. \\
\hline 725 & 10073. & U.S.A. \\
\hline $7^{26}$ & IOII 7 & G.B. . . \\
\hline 727 & 1оा96 & G.B. $\ldots$ \\
\hline 728 & 10229 & U.S.A. \\
\hline 729 & 10475 & U.S.A. \\
\hline $73^{\circ}$ & 10545 & G.B. $\ldots$ \\
\hline 731 & 10547 & G.B. ... \\
\hline $73^{2}$ & I009I & Germany \\
\hline 733 & ro253 & U.S.A. \\
\hline
\end{tabular}

TITLE AND JOURNAL.

Dust Removal Equipment in a Shadow Factory. (Machinery, Vol. 62, No. 1,588, 18/3/43, pp. 298-300.)

The Use and Planning of Works Music (Paper Presented .A.S.M.E.). (H. Burris-Meyer, Mech. World, Vol. II3, No. 2,934, 26/3/43, pp. 338-339.)

Music in Industry. (H. Burris-Meyer, Mech. Eng.. Vol. 65, No. I, Jan., 1943, pp. 31-34.)

Modern Developments in Heating. (F. Buckingham, Mech. World, Vol. I I3, No. 2,938, 23/4/43, pp. 433-436.)

Health in the Magnesium Industry. (H. R. Gay, Metal Industry, Vol. 62, No. 20, I4/5/43, pp. 309-3io.)

Fxplosion Hazards in the Chemical Industry. (T. A. Cohen, Ind. Eng. and Chem. (News Ed.), Vol. 2 I, No. 5, March 1o, I943.)

Safety in Army Ordnance Establishments. (C. Field, A.S.M.E. Preprints, April 26-28, 1943, pp. I-7.)

Safety Precautions in British Factories. (W. Garrett, Trade and Engineering 'Times, Vol. 52,

No. 95, April, 1943, p. 10.)
Music in Factories. (Trade and Engineering Times, Vol. 52, No. 95, April, 1943, p. 22.)

Women in Industry.

Women in German Aircraft Industry (Photo). (Luftwissen, Vol. 1o, No. 3, March, 1943, p. 87.)

The Influence of Women on Aircraft Production Methods. (W. G. Tuttle, Aero Digest, Vol. 42, No. 3, March, I943, pp. $14^{2-1} 43$ and 195-199.)

\section{Land and Water Transport.}

Trucks and Trailers.

7349842 U.S.A. ... Huge Trucks for Hauling Bomber Parts (Photo). (Am. Av., Vol. 6, No. II, I/11/42, p. 40.)

$7359868 \quad$ U.S.A.

$73^{6} \quad 9904$ U.S.A.

7.37 10565 Germany

$73^{8} \quad 10569$ Germany
Motorized Lift Truck. (Am. Av., Vol. 6, No. 17, $1 / 2 / 43$, p. 48 .)

Tractor-Trailer Combination for Transporting Aircraft Parts. (Autom. Eng., Vol. 33, No. 434, March, 1942, p. I 16.)

Details of Caterpillar Tracks for Heavy Rescue Army Lorry. (C. Rabe, Motor Schau., Vol. 7, No. 2, Feb., 1943, pp. 54-57.)

Heavy Caterpillar Trucks for the German Army Fitted with Rescue Winch. (C. Rabe, Motor Schau., Vol. 7, No. 3, March, 1943, pp. 90-94.) 
ITEM R.T.P.

No. Rlik.

TITLE AND JOURNAL.

7399888 U.S.A.

Tunks.

... Women Repairing a 28-Ton M.3 Medium Tank. (Army Ordnance, Vol. 22, No. ${ }_{134}$, Sept.-Oct., I942, p. 276.)

7409891 G.B. ... ... British Covenanter Tanks in Mass Production (Photo). (Army Ordnance, Vol. 22, No. I34, Sept -Oct., 1942, p. 289.)

7+1 9895 U.S.A. ‥ 30-Ton Medium Tank, M.4 (Two Vieus). (Army Ordnance, Vol. 22, No. I34; Sept.-Oct., 1942, p. 306.)

$7 t^{2} \quad 10003$ U.S.A. . . Cardillac M.S. Light Tank (Photograph). (Autom. Ind., Vol. 88 , No. 4 , $15 / 2 / 43$, p. $5^{2}$.)

7+3 10055 G.B. ... ... Constructional Methods and Materials for Pickling Tanks. (A. J. T. Eyles, Mech. World, Vol. II3, No. 2,93 I, $5 / 3 / 43$, p. 247 .)

$7+4 \quad 10113$ G.B. . .

Structural Failure of the Welded Tanker" Schenestady." (Engineering, Vol. I 55, No. 4,034, $7 / 5 / 43$, p. 376.$)$

$745^{\circ} 10402$ U.S.A.

America's M.7 Tank (Photograph). (Autom. Ind., Vol. 88, No. 5, $1 / 3 / 43$, p. 39.)

Electric and Gas-Driven Vehicles.

$746999+$ U.S.A. ... Interchangeability of Parts for Army Vehicles. (E. L. Warner, Autom. Ind., Vol. 88, No. 4, I $5 / 2 / 4^{2}$, pp. 17 and $76-78$.)

747 IOI7I G.B....

Battery Electric Vehicles. (J. W. Macfarlane, Sheet Metal Industry, Vol. I7, No. I93, pp. 856-859 and 862.)

$748 \quad 10478$ U.S.A

Wartime Replacement Parts. (R. Cass, S.A.E. Preprint, May 5-6, 1943, pp. 1-r3.)

74910500 U.S.A.

750 10568. Germany

Electrically Operated Friction Brake for Transport Vehicles. (Sci. Am., Vol. I68, No. 3, March, 1943, p. I 24.)

Mass Production of Gas Generators for Transport Vehicles. (Motor Schau., Vol. 7, No. 2, Feb., 1943, pp. 66-7I.)

\section{Boats.}

75I 1057I Germany ... Gliding Boats for High Speed River Traffic. (H. v. Romer, Motor Schau., Vol. 7, No. 3, March, 1943, pp. IO2-104.)

\section{Electricity.}

Photo-Electric Cells.

752.10172 G.B. ... ... The Spectral Response of Photo-kilectric Cells. (T. M. Chance, Electronic Engineering, Vol. I5, No. $182,4 / 5 / 43$, pp. 50I-504.)

75310173 G.B. ... ... Some Measurements on Selenium Photo-Cells,

(G. A. Veszi, Electronic Engineering, Vol. i 5, No. $182,4 / 5 / 43$.)

75410174 G.B. . Smoke Density Meters Using Photo-Cells. (R. T. Wey, Electronic Engineering, Vol. ${ }_{15}$, No. 182 , $4 / 5 / 43$, pp. 507-5r4.) 


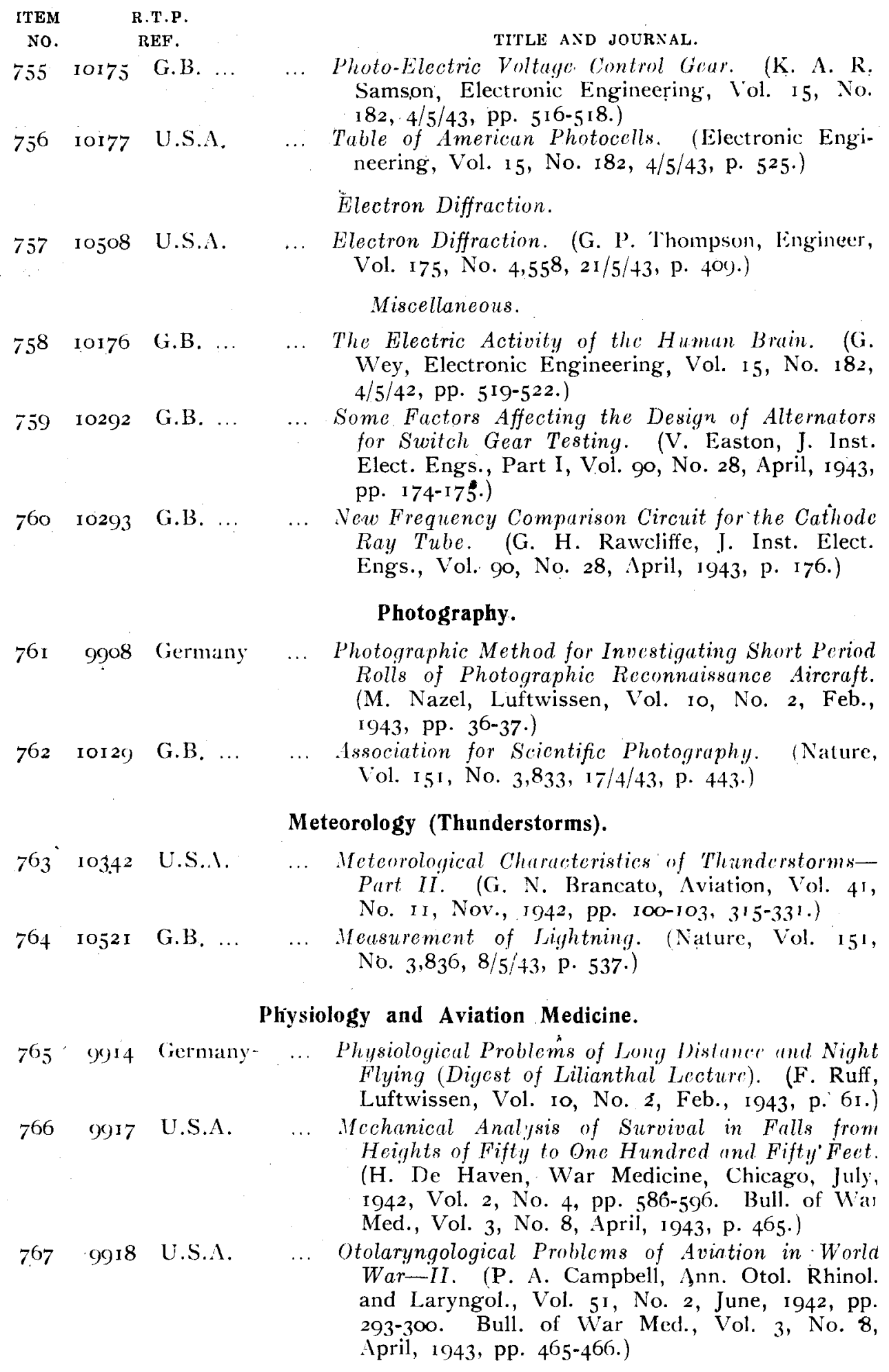




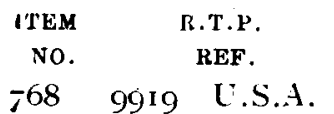

$7699920 \quad$ U.S.A.

992 I Germany

77 I I0027 L.S.A.

$772 \quad$ IO4I $^{2} \quad$ G.B. . .

$773 \quad 10555$ Germany

775 10180. Germany

$77^{6}$ roisi Germany

Tr7 ioi82 Germany

$778 \quad 10183$ Germany

$779 \quad 10184$ Germany
TITLE AND JOURNAL.

The Effect on Hearing of Experimental Occlusion of the Eustachinn Tube. (W. E. Loch, Ann. Otol, Rhinol. and Laryngol., June, 1942, Vol. 51, No. 2, pp. 396-405. Bull. of War Med., Vol. 3, No. 8, April, I943, p. 466.)

The Vature of the Valvular dction (Passive Opening) of the Eustachian Tube in the Relation to Changes of Atmospheric Pressure and Aviation Pressure Deafness. ( $\mathrm{J}$. E. G. McGibbon, J. Laryngol. and Otol., July, 1942, Vol. 57, No: 7, pp. 344-35o. Bull. of War Med., Vol. 3, No. 8, April, 1942, pp. 466-468.)

The Differential Sensitivity of the Dark-Adapted Eye. (Ophthalmologica, Sept, I942, Vol. Iof, No. 3, pp. 157-165. Bull. of Mar Med., Vol. 3, No. 8, April, I943, pp. 468-469.)

An Engineering Discussion of the Desiccation of Human Blood Plasma. (D. C. Pfeiffer, A.S.M.E. Preprint, April, 26-28, I943.)

Anoxamic Changes in the Liver, with Regard to the High Altitude Death of Airman. (P. Ladewig, Nature, Vol. I5I, No. 3,837, i5/5/43, pp. 548-55I.)

Colorimetric Methods for Determining the Concentration of Trinitrotoluol Dust or Vapour in the Air. (Z.G.S.S., Vol. 38, No. 2, Feb., I943, p. $3^{2}$.

\section{Mathematics and Physics.}

Nomogram for Determining the Number of Separate Drauing Operations Required to Produce a Given Ratio in Diameters. (G. Soph and W. Frey, Luftwissen, Vol. Io, No. 2, Feb., r943, p. 43.)

votes on Controlled Type of One Dimensional Motion (Solution of Second Order Non-Linear Differential Equation). (H. Bilhary, Z.A.M.M., Vol. 22, No. 4; Aug., 1942, pp. 206-2 I 5.)

Determination of Most Favourable Interval for the Numerical Integration of Systems of Differential Equation. (L. Collatz, Z.A.M.M., Vol. 22, No. 4. Aug., 1942, pp. 216-225.)

Sub-Division of a Positive Quantity into Positive Parts. Probability of Parts not Exceeding a Certain Limit. (H. Hadwiger, Z.A.M.M., Vol. 22, No. 4, Aug., 1942, pp. 226-232.)

Differential Equations-Method of Solution and Collection of Typical Solutions for Reference (.Additions will be Published Periodically. in Z.A.M.M.). (E. Kanke, Z.A.M.M., Vol. 22, No. 4, Aug., I942, pp. 233-234.)

Conditions for Solution of a System of Equation b!y Iterition. (G. Schulz, Z.A.M.M., Vol. 22. No. 4, Aug., 1942, pp. 234-235.) 


\begin{tabular}{|c|c|c|c|c|}
\hline 464 & & TITLES & AND & REFERENCES OF ARTICLES AXD PAPERS. \\
\hline $\begin{array}{c}\text { ITEM } \\
\text { so. }\end{array}$ & & $\begin{array}{l}\text { T.P. } \\
\text { EEF }\end{array}$ & & TITLE AND JOURNAL. \\
\hline 780 & 10185 & Germany & & $\begin{array}{l}\text { Interpolation in Table having Insqual Steps. (J. } \\
\text { Hernhold, Z.A.M.M., Vol. 22, No. 4, Aug., I942, } \\
\text { pp. 234-235.) }\end{array}$ \\
\hline $7^{81}$ & $104 I x$ & G.B. $\ldots$ & & $\begin{array}{l}\text { The Theory of Emulsions and Their Technical } \\
\text { Treatment (Book Review). (W. Clayton, Nature, } \\
\text { Vol. } 15 \mathrm{I} \text { No. } 337, \mathbf{5} / 5 / 43 \text {. }\end{array}$ \\
\hline 782 & 10536 & Germany & . & $\begin{array}{l}\text { On the Calculation of Approximate. Vapour Pressure } \\
\text { Laws. (J. Esser, Z.G.S.S., Vol. } 38 \text {, No. } 2 \text {, Feb., } \\
\text { I943, pp. } 25-29 .)\end{array}$ \\
\hline-83 & 10539 & G.B. & - & $\begin{array}{l}\text { Analytical Geometry in Common Layouts (I). } \\
\text { The Case of an Undercarriage about a Single Axis. } \\
\text { (S. J. Garvey and K. W. Hertzel, Airc. Eng. } \\
\text { Vol. r5, No. I71, May, I943, pp. I32-134 and } \\
\text { I43.) }\end{array}$ \\
\hline
\end{tabular}

